University of Windsor

Scholarship at UWindsor

\title{
$5-2016$
}

\section{Formation of the Neoarchean Bad Vermilion Lake Anorthosite Complex and Spatially Associated Granitic Rocks at a Convergent Plate Margin, Superior Province, Western Ontario, Canada}

\author{
Ali Polat \\ University of Windsor \\ Shuda Zhou \\ University of Windsor \\ Fred J. Longstaffe \\ Western University \\ Kunguang Yang \\ China University of Geosciences Wuhan \\ Brian J. Fryer \\ University of Windsor

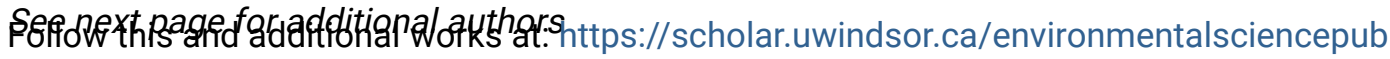 \\ Part of the Geochemistry Commons
}

\footnotetext{
Recommended Citation

Polat, Ali; Zhou, Shuda; Longstaffe, Fred J.; Yang, Kunguang; Fryer, Brian J.; and Weisener, Chris. (2016). Formation of the Neoarchean Bad Vermilion Lake Anorthosite Complex and Spatially Associated Granitic Rocks at a Convergent Plate Margin, Superior Province, Western Ontario, Canada. Gondwana Research, 33, 134-159.

https://scholar.uwindsor.ca/environmentalsciencepub/3
}

This Article is brought to you for free and open access by the Earth \& Environmental Sciences at Scholarship at UWindsor. It has been accepted for inclusion in Earth \& Environmental Sciences Publications by an authorized administrator of Scholarship at UWindsor. For more information, please contact scholarship@uwindsor.ca. 


\section{Authors}

Ali Polat, Shuda Zhou, Fred J. Longstaffe, Kunguang Yang, Brian J. Fryer, and Chris Weisener 

$20 *$ Corresponding author. E-mail address: polat@uwindsor.ca (A. Polat). Anorthosite Complex and Spatially Associated Granitic Rocks at a Convergent Plate Margin, Superior Province, Western Ontario, Canada

Shuda Zhou ${ }^{\mathrm{a}}$, Ali Polat ${ }^{\mathrm{a}, *}$, Fred J. Longstaffe ${ }^{\mathrm{b}}$, Kunguang Yang $^{\mathrm{c}}$, Brian J. Fryer ${ }^{\mathrm{a}, \mathrm{d}}$, Chris Weisener ${ }^{\mathrm{a}, \mathrm{d}}$

${ }^{a}$ Department of Earth and Environmental Sciences, University of Windsor, Windsor, ON, Canada N9B 3P4

${ }^{\mathrm{b}}$ Department of Earth Sciences, The University of Western Ontario, London, N6A 5B7 ON, Canada ${ }^{c}$ Faculty of Earth Sciences, China University of Geosciences, Wuhan 430074, China

${ }^{\mathrm{d}}$ Great Lakes Institute for Environmental Research, University of Windsor, Windsor, ON, Canada N9B 3P4 17 18 9 
Abstract

The Bad Vermilion Lake Anorthosite Complex (henceforth, the BVLA Complex) in western Ontario is one of the well-exposed, anorthosite-bearing, Archean layered intrusions in the Superior Province, Canada. This study presents new whole-rock major and trace element data for the various units of the Complex, oxygen isotope data for the anorthosite, and major and trace element data for the spatially associated granitic rocks intruding the BVLA Complex to constrain

27 their petrogenetic and geodynamic origin. Zircons from granitic rocks have yielded a ${ }^{207} \mathrm{~Pb} /{ }^{206} \mathrm{~Pb}$ age of $2716 \pm 18 \mathrm{Ma}$, constraining the minimum intrusion age of the Complex. locally well preserved in the BVLA Complex. Its whole-rock major and trace elemental compositions and the oxygen isotopic systematics appear not to have been substantially modified by deformation and metamorphism. Mantle-like oxygen isotope signatures and major and trace element compositions are inconsistent with significant crustal contamination of the BVLA Complex during its emplacement. The existence of primary calcic igneous plagioclase, coherent negative $\mathrm{Nb}$ anomalies $\left(\mathrm{Nb} / \mathrm{Nb}^{*}=0.08-0.88\right)$, and geochemical similarities between gabbros from the BVLA Complex and gabbros from Cenozoic arcs collectively suggest an intra-oceanic subduction zone geodynamic setting for the Complex. Near-flat REE patterns in the various units of the BVLA Complex suggest that they were derived from melting of a shallow source beneath a subarc mantle wedge. Trends in immobile major (e.g., $\mathrm{MgO}$ ) and trace (e.g., $\mathrm{Zr}$ ) element data indicate that the mineralogical composition of the Complex can be explained by fractional crystallization and accumulation of olivine, orthopyroxene, clinopyroxene, plagioclase and 
42 possibly amphibole.

43 Compositionally, the bordering granitic rocks are $\mathrm{A}_{2}$-type and strongly enriched in $\mathrm{Th}$ and $44 \quad \operatorname{REE}(>100$ times chondrite) and depleted of $\mathrm{Ba}, \mathrm{Sr}, \mathrm{Eu}$ and Ti. We suggest that they formed in a 45 post-collisional, extensional, tectonic regime following emplacement of the BVLA Complex in 46 an oceanic arc.

47

48 Key words: Bad Vermilion Lake Complex, Anorthosite, Archean, Oxygen Isotope, Zircon U-Pb 49 dating

\section{Introduction}

Although Archean layered anorthosites and associated leucogabbros, gabbros and ultramafic rocks (Ashwal, 1993; Bédard et al., 2009; Polat et al., 2009, 2010, 2012; Leclerc et al., 2011;

54 Hoffmann et al., 2012; Mohan et al., 2013) are volumetrically minor components of the 55 preserved Archean crust, they occur in most Archean cratons (e.g., Superior Province, Greenland, 56 South India) (Fig. 1). They are typically associated with greenstone belts and hold critical

57 information on the petrogenetic and geodynamic processes that operated in the early Earth 58 (Ashwal, 1993; Polat et al., 2009, 2010, 2012; Mohan et al., 2013). contributed to the unique mineralogical, geochemical, and textural characteristics of these

62 Hoffmann, 2012; Polat et al., 2012). The conventional viewpoint has been that Archean 
anorthosite complexes formed from the residual liquid of an anhydrous basaltic melt that remained after crystallization and accumulation of ultramafic minerals, such as olivine and pyroxene. This geodynamic setting is similar to that of the mid-ocean ridge basalts (Ashwal, 1993; Ashwal et al., 1994; Phinney et al., 1988). Other studies of Archean anorthosite complexes in various cratons, such as Greenland and India, have suggested, however, that the complexes were derived from hydrous sub-arc mantle sources (Windley et al. 1973; Polat et al., 2009, 2010, 2011, 2012; Rollinson, 2010; Rao et al., 2013; Hoffmann et al., 2012).

The reason for the debate is that all Archean anorthosite complexes underwent multiple phases of metamorphism and deformation, resulting in strong modification of their primary textures and mineralogical compositions. These modifications make it difficult to determine the parental magma compositions and tectonic setting of these complexes. Moreover, many typical Archean anorthosite complexes are understudied; only a few have been examined in detail using modern, high-precision, geochemical techniques (Berger et al., 2013; Mohan et al., 2013; Polat et al., 2009, 2010, 2012; Rao et al., 2013). Thus, their source characteristics, and petrogenetic and geodynamic origins are not well constrained.

Anorthosite complexes are best known and well exposed in the Archean granite-greenstone terranes of the Superior Province of Canada (Fig. 1). Some important features of several typical Archean anorthosite complexes in the Superior Province are listed in Table 1. All underwent various grades of metamorphism and degrees of deformation. Most complexes, however, preserve pristine igneous textures with large equant, euhedral to subhedral calcic plagioclase megacrysts (An > 80) being present in many layers (e.g., Ashwal, 1993; Ashwal et al., 1983; 
Bédard et al., 2009; Leclerc et al., 2011).

Among these anorthosite complexes, the Neoarchean (ca. $2700 \mathrm{Ma}$ ) Bad Vermilion Lake Anorthosite Complex (BVLA Complex) is one of the least metamorphosed and least deformed examples of Archean anorthositic layered intrusions in the Superior Province (Table 1). Primary field relationships are well exposed in which the Complex intrudes mafic to felsic volcanic rocks of the Bad Vermilion Lake greenstone belt (Wood et al., 1980). The BVLA Complex has been variably metamorphosed to greenschist facies as reflected by the presence of hydrothermal alteration and greenschist metamorphic mineral assemblages (Ashwal et al., 1983). Shear zones, foliation and small-scale folds are not widespread in the BVLA Complex. Primary igneous textures are well preserved in many outcrops (Ashwal et al., 1983). Most plagioclase grains retain their primary equant shapes, and show elongation only in the shear zones (Phinney et al., 1988). Thus, the BVLA Complex provides an excellent opportunity to study the petrogenesis and tectonic setting of Archean anorthosite complexes in the Superior Province.

Despite its good preservation, there remain several outstanding problems in regards to the petrogenetic and geodynamic origin of the BVLA Complex: (1) The petrography and mineralogy of the BVLA Complex are understudied. For example, several significant lithological units (such as leucogabbros) of the Complex, as well as temporally and spatially associated granitic rocks, remain uninvestigated. (2) The existing whole-rock major and trace element data, which were obtained by X-ray Fluorescence and Instrumental Neutron Activation Analysis (Ashwal et al., 1983), are insufficient for describing the petrogenesis of the BVLA Complex. Data for several petrogenetically important elements (e.g., Ba, V, Nb, Zr, Y, Pr, Gd, Dy, Ho, Er, and Tm) are still 
required. (3) Previous studies (Ashwal, 1983; Ashwal et al., 1985) did not define the tectonic setting of the BVLA Complex. (4) The origin and evolution of the parental magmas to the BVLA Complex are not well understood. (5) The ages of the BVLA Complex and the bordering granitic rocks are poorly constrained (Ashwal et al., 1983, 1985).

In order to address these problems, we have conducted integrated field, petrographic, whole-rock major and trace element, whole-rock and mineral oxygen isotope studies of the BVLA Complex, and petrographic, whole-rock major and trace element and zircon U-Pb dating studies of the spatially associated granitic rocks. The objectives of this study of the BVLA Complex are: (1) to identify its primary versus secondary (metamorphic) textures and mineral assemblages; (2) to gain new insights into the petrogenesis of its anorthosites and associated rock types; (3) to constrain its age and that of the bordering granitic intrusions; (4) to determine the tectonic setting in which the BVLA Complex formed; and (5) to better constrain the nature of the crust (oceanic versus continental) into which it was emplaced.

\section{Regional Geology}

\subsection{Western Superior Province}

The Superior Province (Figs. 1 and 2) is the largest Archean craton in the world, composing $23 \%$ of the Earth's exposed Archean crust (Percival et al., 2012). It is exposed in the central part of the North American continent and together with other Archean cratons and Proterozoic orogens, makes up the Canadian Shield (Hoffman, 1988). It is composed of diverse types of igneous and sedimentary rocks metamorphosed at sub-greenschist to granulite facies and 
stabilized around 2.65 Ga ago (Percival et al., 1988, 2012).

Based on general structural and lithological characteristics, the Superior Province is divided into four regions: the Western Superior Province, the Central Superior Province, the Moyen-Nord Province, and the Northeastern Superior Province (Percival et al., 2012). The Western Superior region is composed of the area extending from Phanerozoic cover rocks in the west and north, to Lake Superior to the southeast.

On the basis of identified tectonic boundaries, the Western Superior Province is divided into eleven east-west-trending subprovinces (Fig. 2) (Card and Ciesielski, 1986; Williams et al., 1992; Stott, 1997; Card and Poulsen, 1998; Percival et al., 2012). These subprovinces consist mainly of alternating sedimentary and igneous terranes. The northernmost subprovince of the Western Superior Province is the North Caribou Superterrane, which is characterized by well-exposed crustal rocks having ca. 3.0 Ga depleted mantle model ages. This subprovince has been thought to be a relict fragment of Mesoarchean continental crust and the nucleus of the Superior Province (Thurston et al., 1991; Stott and Corfu, 1991). Later sedimentary and tectonic processes added the younger lithotectonic assemblages to this continental nucleus (Corfu and Stott, 1993, 1996; Sanborn-Barrie et al., 2001; Thurston, 2002; Percival et al., 2001, 2002). The English River subprovince to the south is composed predominantly of turbiditic greywackes that are interpreted to have been deposited in a syn-orogenic sedimentary basin (Percival et al., 2006). Deposition of the greywackes in the English River subprovince is attributed to the tectonic juxtaposition of the ca. 2.70 Ga Winnipeg River subprovince and an old $(<3.4 \mathrm{Ga})$ relatively small continental fragment to the south (Westerman, 1978; Gower and Clifford, 1981; Davis et al., 1988; Davis 
147 and Smith, 1991; Beakhouse, 1991; Cruden et al., 1997, 1998). The Winnipeg River subprovince

148 appears to extend eastward into the central Wabigoon subprovince (Fig. 2). The Wabigoon

149 subprovince farther south contains numerous sequences of volcanic and sedimentary supracrustal

150 rocks and granitoid plutons. The $<2698$ Ma metasedimentary rocks of the Quetico subprovince

151 represent a flysch sequence deposited in response to a collision between the Wabigoon

152 subprovince to the north and the Abitibi-Wawa composite terrane to the south (Davis et al., 153 1990).

\subsection{The Western Wabigoon subprovince}

156

The Wabigoon subprovince (Fig. 2) is a $900 \mathrm{~km}$-long, $150 \mathrm{~km}$-wide granite-greenstone

157 subprovince in the western Superior Province (Blackburn et al., 1991). It is bounded by the

158 metaplutonic Winnipeg River subprovince to the northwest, the metasedimentary to migmatitic

159 English River subprovince to the northeast and the metasedimentary Quetico subprovince to the

160 south. The Wabigoon subprovince is composed of ca. 3.0 to $2.71 \mathrm{Ga}$ metamorphosed volcanic

161 rocks and subordinate sedimentary rocks. These rocks were surrounded and intruded by circa 3.0

162 to $2.69 \mathrm{Ga}$ gabbroic sills, granitoid batholiths and stocks.

163 The subprovince is divided into three distinct domains based on geographic distribution of

164 lithological associations, including the western, central, and eastern Wabigoon regions

165 (Blackburn et al., 1991). The western Wabigoon region is dominated by interconnected 166 supracrustal belts and intruding large tonalite-granodiorite plutons (Blackburn et al., 1991).

167 Volcanic rocks in the region are compositionally variable, ranging from ultramafic (komatiite), 
168

169

170

171

172

173

174

175

176

177

178

179

180

181

182

183

184

185

186

187

188

through mafic and intermediate, to felsic rocks. They are compositionally tholeiite and calc-alkaline suites and are interpreted to represent fragments of Archean oceanic crust and island arcs, respectively (Percival et al., 2012). The ages of the volcanic rocks range mainly

between 2.745 to $2.720 \mathrm{Ga}$, with minor older $(2.775 \mathrm{Ga})$ and younger $(2.71-2.70 \mathrm{Ga})$ components (Corfu and Davis 1992). Sedimentary sequences in the western Wabigoon region are commonly younger than the volcanic counterparts and were deposited between $\sim 2.711$ and 2.698

Ga, as illustrated by local unconformable relationships and geochronological data (Davis, 1996; 1998; Fralick 1997; Fralick and Davis 1999). The central region is characterized by large volume of granitoid batholiths and small volume of supracrustal rocks (Blackburn et al., 1991). The eastern Wabigoon region consists mainly of Mesoarchean to Neoarchean supracrustal rocks and granitoid plutons (Percival et al., 2012).

\subsection{The Bad Vermilion Lake area}

The Bad Vermilion Lake area is underlain by low-grade metaigneous and metasedimentary rocks and forms part of the southwestern end of the Wabigoon subprovince in western Ontario (Fig. 3) (Mackasey et al., 1974). It is located at the boundary between the Wabigoon and Quetico subprovinces (Fig. 3). It is separated by the Quetico Fault from migmatitic rocks (Rainy Lake batholithic complex) to the north, and by the Seine River Fault to the south from higher-grade epiclastic metasedimentary rocks (Seine metasedimentary rocks) of the Quetico subprovince (Wood et al., 1980).

The ca. 2700 Ma BVLA Complex (Figs. 3 and 4) is exposed over an area of about $100 \mathrm{~km}^{2}$ 
189 (Ashwal et al., 1983). It composed of anorthosite, leucogabbro and gabbro with minor mafic 190 dykes and sills. The anorthosites in the BVLA Complex occur within a wedge of gabbros, mafic 191 to felsic volcanic rocks, and granitic rocks (Figs. 3 and 4). The anorthosites are exposed along 192 the shores of Bad Vermilion Lake, the southern shores of Seine Bay, and on the Seven Sisters 193 Islands near the international border (Wood et al., 1980; Harris, 1974). They form a 194 tadpole-shaped mass with an open "s"-fold configuration. The anorthosites are intruded by 50 195 centimeters to 15 meters wide, discontinuous mafic dykes, with a relict ophitic (microgabbroic) 196 texture. Large, elongate gabbroic bodies are exposed along the northern and southern margins of the anorthositic layers. The northern gabbro contains discrete layers or lenses of massive Fe-Ti oxides with northeast strikes and vertical dips (Harris 1974; Wood et al., 1980). These Fe-Ti oxide masses are particularly abundant in the exposures north of Seine Bay (Ontario Department of Mines, 1961; Ashwal, 1983).

Boundaries between gabbro and anorthosite layers are sharp, whereas they are transitional between the leucogabbro and anorthosite layers (Fig. 5). The anorthosites are composed of coarse-grained $(1-20 \mathrm{~cm})$, equidimensional, euhedral to subhedral plagioclase, in a finer-grained mafic matrix (Fig. 5). The amount of mafic matrix in individual anorthosite and gabbro samples ranges from near zero to about $60 \%$ by volume (Ashwal et al., 1983). Distinct cumulate layers within the anorthositic unit are not well exposed, but many outcrops display changes in grain-size (Morrison et al., 1987). Layering within the gabbroic parts of the Complex is more obvious and common. The gabbros are fine-grained but locally they contain megacrystic plagioclase grains (Fig. 5). 
211 having undergone partial to complete pseudomorphic replacement by aggregates of zoisite and

212 other epidote minerals; many anorthosite outcrops, nonetheless, contain some relict primary

213 plagioclase. Nearly all of the mafic silicates of the BVLA Complex have been altered to a 214 mixture of fine-grained chlorite, actinolite and amphibole with only rare remnants of pyroxene.

215 There is very little deformation in the Complex except in localized shear zones.

217 3. Analytical methods

$218 \quad 3.1$. Sampling

A total of 40 samples devoid of any surface alteration or weathering were collected from the BVLA Complex and associated intrusive granitic rocks. The sample suite provides a comprehensive spatial distribution of the anorthosite unit in the BVLA Complex, and covers all 222 of its major rock types.

\subsection{Petrographic investigation}

The microscopic images were obtained at the Department of Earth and Environmental 226 Sciences, University of Windsor, Windsor (Ontario) Canada, using an Olympus BX51 227 petrographic microscope. This microscope is equipped with a Luminera Infinity 1 228 high-resolution, digital/video camera coupled with capture software. It has both transmitted- and 229 reflected-light capabilities. Some minerals that were difficult to identify using traditional microscopic methods were identified using an Environmental Scanning Electron Microscope 
231 (EDAX FEI Quanta 200 FEG environmental SEM) at the Great Lakes Institute for 232 Environmental Research (GLIER), University of Windsor. This SEM is equipped for 233 Backscattered Electron (BSE) imaging and elemental analysis/mapping using Energy Dispersive 234 X-ray Spectrometry (EDS) and cathodoluminescence. EDS analyses were performed under 235 high-vacuum conditions, using a beam size of $\sim 3.0 \mu \mathrm{m}$, an accelerating voltage of $20 \mathrm{kV}$, a counting time of at least 30 seconds and an approximate working distance of 12 millimeters.

\subsection{Zircon separation and $U-P b$ analysis}

About $8 \mathrm{~kg}$ of two representative samples (BVL2013-042, BVL2013-043) of granitic rocks intruding the BVLA Complex were crushed and milled. Standard heavy liquid and magnetic techniques were used to separate zircon concentrates, which were then purified by hand 242 picking under a binocular microscope. The least metamict and least damaged grains were chosen 243 for analyses. These grains were cast into epoxy resin discs and polished to expose the 244 mid-sections of grains. Further assessment of grains and choice of sites for analyses was based 245 on transmitted and reflected light, as well as cathodoluminescence (CL) and back-scattered 246 electron (BSE) images.

247 Zircon U-Pb dating of the samples was carried out using LA-ICP-MS at the State Key 248 Laboratory of Geological Processes and Mineral Resources, China University of Geosciences, 249 Wuhan, People's Republic of China. Details of the operating conditions for the laser ablation 250 system and the ICP-MS instrument and data reduction are the same as described in Liu et al. 251 (2010). An Agilent 7500a ICP-MS instrument was used to acquire ion-signal intensities. A 
"wire" signal smoothing device is included in this laser ablation system, by which smooth

253 signals are produced even at very low laser repetition rates down to $1 \mathrm{~Hz}$ (Hu et al., 2012).

254 Helium was used as a carrier gas. Argon was used as the make-up gas and mixed with the carrier

255 gas via a T-connector before entering the ICP. Nitrogen was added into the central gas flow

256 (Ar+He) of the Ar plasma to decrease the detection limit and improve precision (Liu et al., 2010).

257 Each analysis incorporated a background acquisition of approximately 20-30 seconds (gas blank)

258 followed by 50 seconds data acquisition from the sample. The Agilent Chemstation was utilized

259 for the acquisition of each individual analysis.

260 Grouped ages discussed in the text are reported with uncertainties of $\pm 1 \sigma$. Data were

261 plotted on Concordia diagrams using Isoplot/Ex (Ludwig, 2008).

\subsection{Major and trace elements}

Details of analytical methods for major and trace elements are given in Polat et al. (2009).

All samples were powdered using an agate mill and were analyzed for major and some trace

ENVIRO II ICP and following the lithium metaborate/tetraborate fusion method. Samples were

269 induction furnace. The molten beads were rapidly dissolved in a solution of $5 \% \mathrm{HNO}_{3}$ 
273 precision of $1-2 \%$ for most major elements.

274 Other trace element concentrations, including large ion lithophile elements (LILE; e.g., Rb), 275 rare earth elements (REE; e.g., La-Lu) and, high field strength elements (HFSE: e.g., Zr, Nb, Ta), 276 were determined using an inductively coupled plasma-mass spectrometer (ICP-MS Thermo X 277 Series II) at GLIER, following the protocols of Jenner et al. (1990). Sample dissolution was 278 conducted under clean laboratory conditions using doubly distilled acids. Approximately 279 100-120 mg of sample powder was used for acid digestion. Briefly, samples were dissolved in 280 Teflon bombs in a concentrated mixture of $\mathrm{HF}-\mathrm{HNO}_{3}$ at $\sim 120^{\circ} \mathrm{C}$ for 4 days and then further 281 digested using 50\% $\mathrm{HNO}_{3}$ and $\mathrm{H}_{3} \mathrm{BO}_{4}(5000 \mathrm{ppm}$ B) until no solid residue remained. 282 International standards BHVO-1 and BIR-1 were used as reference materials. Anomalies of 283 HFSE relative to neighboring REE are given as $\mathrm{Nb} / \mathrm{Nb}^{*}, \mathrm{Zr} / \mathrm{Zr}$, $\mathrm{Hf} / \mathrm{Hf}^{*}$ and $\mathrm{Ti} / \mathrm{Ti}^{*}$. 284 Mg-numbers (\%) were calculated as the molar ratio of $\mathrm{Mg}^{2+} /\left(\mathrm{Mg}^{2+}+\mathrm{Fe}^{2+}\right)$, where $\mathrm{Fe}^{2+}$ is assumed to be $90 \%$ of the total Fe.

\subsection{Oxygen isotope analyses}

Five whole-rock samples, and ten fresh and five altered plagioclase separates were analyzed for oxygen isotope compositions. The sample selection was designed to determine the isotopic differences between least and most altered samples, and hence assess the effect of metamorphic alteration on plagioclase oxygen isotope composition. Mineral separation was performed at the University of Windsor. Crushed-samples were cleaned with distilled water, after which the fresh plagioclase and altered plagioclase grains were hand-picked using a reflected 
294 binocular microscope.

295 Oxygen-isotope analyses of mineral separates and whole-rock powders were performed at 296 the Laboratory for Stable Isotope Science (LSIS), The University of Western Ontario, London 297 (Ontario), Canada. Details of oxygen isotope analyses are given in Polat and Longstaffe (2014). 298 For all samples, approximately $8 \mathrm{mg}$ of sample powder were weighed into spring-loaded sample 299 holders, evacuated overnight at ca. $150{ }^{\circ} \mathrm{C}$, and then placed into nickel reaction vessels and 300 heated in vacuo at $300{ }^{\circ} \mathrm{C}$ for further 3 hours to remove surface water. The samples were then 301 reacted overnight at ca. $580{ }^{\circ} \mathrm{C}$ with $\mathrm{ClF}_{3}$ to release silicate-bound oxygen (Borthwick and 302 Harmon, 1982 following Clayton and Mayeda, 1963). The oxygen was converted to $\mathrm{CO}_{2}$ over 303 red-hot graphite, followed by isotopic measurement using a Prism II dual-inlet, 304 stable-isotope-ratio mass- spectrometer.

305 The oxygen isotopic analyses are reported using $\delta$-notation in parts per thousand (\%) 306 relative to Vienna Standard Mean Ocean Water (VSMOW). Details of the calibration to

307 VSMOW are given in Polat and Longstaffe (2014). The reproducibility of $\delta^{18} \mathrm{O}$ values for samples was $\pm 0.2 \%$. Accuracy was evaluated using internal laboratory quartz and $\mathrm{CO}_{2}$ gas 309 standards for which values of $+11.5 \%$ and $+10.27 \%$ were obtained, which compares well with their expected values of $+11.5 \%$ and $+10.30 \%$, respectively.

\section{Results}

\subsection{Petrography}

Thirty polished thin sections from all major lithological units were examined (Figs. 6 and 
315 7). The anorthosite consists of plagioclase (85-90\%), amphibole (0-5\%), clinopyroxene (0-5\%)

316 and accessory minerals (3\%) such as magnetite and titanite (Fig. 6). Although many anorthite

317 crystals have been altered to albite and epidote, high-Ca, primary anorthite crystals have been

318 preserved in many samples (Figs. 6 and 7). The interstitial mafic matrix consists mainly of

319 chlorite, amphibole, albite, calcite, and quartz. Quartz and calcite contents occasionally exceed

$3205 \%$, mainly adjacent to and within highly strained regions where quartz veining is common.

321

The leucogabbro and gabbro are mineralogically comparable to the anorthosite but

322 contain higher proportions of amphibole, clinopyroxene and orthopyroxene. Coarse-grained

323 layered gabbro and microgabbro (mafic dyke) have similar mineralogical compositions. They

324 have undergone greenschist metamorphism and/or hydrothermal alteration (Figs. 6 and 7). The

325 alteration is mainly characterized by epidote (clinozoisite) after plagioclase, and chlorite after

326 amphibole, clinopyroxene and orthopyroxene. The gabbroic rocks display typical metamorphic

327 textures characterized by a large percentage of rutile grains $(10 \%)$ interlayered with titanite $(10 \%)$

328 within the presumed cleavages of pyroxene (Fig. 7).

329 Granitic rocks generally have a heterogranular texture. They are medium- to coarse-grained,

330 and contain $\sim 25 \%$ plagioclase, $\sim 55 \%$ quartz, $\sim 10 \%$ biotite and $\sim 5-10 \%$ K-feldspar with

331 accessory magnetite, titanite, apatite and zircon (Fig. 8). In plane-polarized light, areas that are

332 clear and white are mostly quartz and plagioclase (Fig. 8). Plagioclase grains are subhedral to

333 euhedral and commonly twinned, but some plagioclase has been altered to fine-grained epidote

334 (Fig. 8). Quartz occurs as aggregates of large grains, or as small grains either in plagioclase or

335 along some grain boundaries (Fig. 8). Biotite occurs mainly as interstitial grains around larger 
crystals of plagioclase, K-feldspar and quartz (Fig. 8).

\subsection{Zircon $U-P b$ dating}

The selected CL images for zircons from samples BVL-2013-042 and BVL-2013-043 are

presented in Figures 9 and 10. Zircon grains from granitic sample BVL2013-042 are colorless to Table 2).

Zircon crystals from granitic sample BVL2013-043 are euhedral to subhedral, transparent and light yellow. They range in length from 100 to $200 \mu \mathrm{m}$ with aspect ratios of $1.5: 1-2.5: 1$. CL imaging reveals that these zircon crystals generally have oscillatory zoning (Fig. 10). Thirty-two

353 spot analyses were obtained on rims of 32 zircon grains, and have $\mathrm{Th} / \mathrm{U}$ ratios of $0.54-0.92$

354 (Table 2). The analyses yield a weighed ${ }^{207} \mathrm{~Pb} /{ }^{206} \mathrm{~Pb}$ age of $2716 \pm 18 \mathrm{Ma}$ (MSWD = 0.58) (Fig. 355 11; Table 2). 

372 (Table 3) (Hofmann, 1988).

373

\subsection{Geochemistry} below.

The geological data and key elemental ratios for the major rock types of the BVLA Complex and the associated granitic rocks are presented in Tables 3, 4 and 5. The salient major, trace and REE features of the rocks in the BVLA Complex and the granitic rocks are presented

\subsubsection{Anorthosites and leucogabbros}

The anorthosite and leucogabbro exhibit small to moderate variations in $\mathrm{SiO}_{2}$ (43.0-49.7 wt.\%), $\mathrm{Al}_{2} \mathrm{O}_{3}$ (17.2-28.8 wt.\%) and $\mathrm{CaO}$ (8.8-17.4 wt.\%) (Figs. 12 and 13; Table 3). In contrast, they are characterized by large variations in $\mathrm{TiO}_{2}(0.14-0.92$ wt.\%), $\mathrm{MgO}(0.73-6.02$ wt.\%), $\mathrm{Fe}_{2} \mathrm{O}_{3}\left(2.57-10.42\right.$ wt.\%), $\mathrm{K}_{2} \mathrm{O}\left(0.02-1.20\right.$ wt.\%), and $\mathrm{Na}_{2} \mathrm{O}$ (0.19-3.30 wt.\%) (Table 3). They also have large ranges of $\mathrm{Zr}$ (5-51 ppm), Ni (24-154 ppm), and Cr (9-518 ppm) contents (Fig. 14; Table 3). Mg-numbers range from 35 to 64 (Table 3). In addition, they display a large range of $\mathrm{Al}_{2} \mathrm{O}_{3} / \mathrm{TiO}_{2}$ (17.7-193), Ti/Zr (67-1051), and $\mathrm{Zr} / \mathrm{Y}$ (1.0-6.4) ratios (Table 3). Except for one outlier, the ratios of $\mathrm{Y} / \mathrm{Ho}$ range from 20 to 38 in comparison to the primitive mantle values of 28

On chondrite-normalized REE and primitive-normalized trace element diagrams (Fig. 15), the anorthosite and leucogabbro samples have the following characteristics: (1) slightly enriched LREE patterns $\left(\mathrm{La} / \mathrm{Sm}_{\mathrm{cn}}=1.04-2.82 ; \mathrm{La} / \mathrm{Yb}_{\mathrm{cn}}=1.28-5.48\right)$ and slightly enriched to flat HREE $\left(\mathrm{Gd} / \mathrm{Yb}_{\mathrm{cn}}=1.04-2.02\right)$ patterns with one outlier; (2) strong positive $\mathrm{Eu}$ anomalies $\left(\mathrm{Eu} / \mathrm{Eu}^{*}=\right.$ 
377

378

379

380

381

382

383

384

385

386

387

388

389

390

391

392

393

394

395

396

1.35-4.49); (3) minor to absent $\mathrm{Ce}$ anomalies $\left(\mathrm{Ce} / \mathrm{Ce}^{*}=0.98-1.05\right)$; and (4) negative anomalies of

$\mathrm{Nb}\left(\mathrm{Nb} / \mathrm{Nb}^{*}=0.08-0.88\right)$ and $\mathrm{Ti}\left(\mathrm{Ti} / \mathrm{Ti}^{*}=0.20-0.95\right.$ with a few exceptions $)$.

\subsubsection{Gabbro}

The gabbro samples, with one outlier, are compositionally variable with 41-59 wt.\% $\mathrm{SiO}_{2}, 11.3-22.6$ wt. $\% \mathrm{Al}_{2} \mathrm{O}_{3}, 6.8-15.1$ wt. $\% \mathrm{CaO}, 7.5-16.4$ wt. $\% \mathrm{Fe}_{2} \mathrm{O}_{3}, 0.02-3.63$ wt.\% $\mathrm{Na}_{2} \mathrm{O}$, 0.39-1.57 wt.\% $\mathrm{TiO}_{2}$, and 2.25-8.44 wt.\% MgO (Figs. 12 and 13; Table 4). They display a large range of $\mathrm{Al}_{2} \mathrm{O}_{3} / \mathrm{TiO}_{2}(9-34), \mathrm{Zr} / \mathrm{Y}(0.73-4.22)$ and $\mathrm{Ti} / \mathrm{Zr}(114-1146)$ ratios. $\mathrm{Mg}$ - numbers span 37-60 (Table 4).

On basis of trace element patterns, the gabbro samples can be divided into two groups.

Group 1 possesses zero to slightly negative $\mathrm{Eu}$ anomalies $(\mathrm{Eu} / \mathrm{Eu} *=0.73-1.06)$ and slightly positive $\mathrm{Ti}$ anomalies $\left(\mathrm{Ti} / \mathrm{Ti}^{*}=0.96-1.31\right)$ (Fig. 15). Group 1 gabbro also shows moderate negative $\mathrm{Nb}$ anomalies with $\mathrm{Nb} / \mathrm{Nb}^{*}$ ratio ranging from 0.21 to 0.86 . In addition, $\mathrm{SiO}_{2}$ concentration ranges from 47.4 to $49.6 \mathrm{wt} . \%, \mathrm{Zr}$ concentration $(55-104 \mathrm{ppm})$ is relatively high, and $\mathrm{Ti} / \mathrm{Zr}$ ratios range from 134 to 160 . Group 2 gabbro has strongly enriched Eu with a Eu/Eu* ratio of 2.0-3.3 and strong positive $\mathrm{Ti}$ anomalies (1.75-2.55) (Fig. 15). Group 2 gabbro also shows slightly depleted to moderately enriched $\mathrm{Nb}$ with $\mathrm{Nb} / \mathrm{Nb}^{*}$ ranging from $0.93-3.08$ (Fig. 15). $\mathrm{SiO}_{2}$ contents are low (41.0-44.6 wt.\%) and $\mathrm{Zr}$ contents are very low (5-8 ppm). Ti/Zr ratios range from 713-1146 (Table 4). Both groups display slightly depleted to slightly enriched LREE patterns $\left(\mathrm{La} / \mathrm{Sm}_{\mathrm{cn}}=0.68-1.47 ; \mathrm{Gd} / \mathrm{Yb}_{\mathrm{cn}}=0.74-2.05\right)$ and slightly enriched HREE patterns with 
one outlier $\left(\mathrm{La} / \mathrm{Yb}_{\mathrm{cn}}=1.07-2.52\right)$. In addition, cerium anomalies $(\mathrm{Ce} / \mathrm{Ce} *=0.99-1.06)$ are minor to absent (Fig. 15; Table 4).

\subsubsection{Granitic rocks}

401

The granitic rocks are characterized by high $\mathrm{SiO}_{2}$ (75.6-77.8 wt.\%), relatively low $\mathrm{Al}_{2} \mathrm{O}_{3}$

402 (10.8 to 11.6 wt.\%), low $\mathrm{K}_{2} \mathrm{O}\left(0.26-2.13\right.$ wt.\%), variable $\mathrm{Na}_{2} \mathrm{O} / \mathrm{K}_{2} \mathrm{O}\left(\mathrm{Na}_{2} \mathrm{O} / \mathrm{K}_{2} \mathrm{O}=1.3-19.7\right)$ and 403 low $\mathrm{MgO}$ (0.03-0.15 wt.\%). They display metaluminous to peraluminous features with $\mathrm{A} / \mathrm{CNK}$ ratios from 0.83-1.17 (Supplementary Fig. 1). They have very low Ni (8.33-14.26 ppm) contents. In addition, they show slightly enriched LREE patterns with $\mathrm{La} / \mathrm{Yb}_{\mathrm{cn}}=2.36$ to 3.22 and negative Eu anomalies $\left(\mathrm{Eu} / \mathrm{Eu}^{*}=0.43-0.59\right)$ on the chondrite-normalized REE diagram (Fig. 16, Table 5). All samples have minor $\mathrm{Ce}$ anomalies $\left(\mathrm{Ce} / \mathrm{Ce}^{*}=1.0-1.07\right)$ and very low $\mathrm{Sr} / \mathrm{Y}(0.40-1.25)$ ratios. The primitive mantle-normalized trace element patterns are characterized by elevated $\mathrm{Th}$, and negative $\mathrm{Nb}(\mathrm{Ta})\left(\mathrm{Nb} / \mathrm{Nb}^{*}=0.42-0.59\right), \mathrm{Sr}\left(\mathrm{Sr} / \mathrm{Sr}^{*}=0.05-0.14\right)$ and $\mathrm{Ti}(\mathrm{Ti} / \mathrm{Ti} *=0.04-0.07)$ anomalies (Fig. 16; Table 5).

\subsection{Oxygen isotopes}

Except for one outlier (BVL2013-077), the whole-rock oxygen isotope compositions $414\left(\delta^{18} \mathrm{O}=+5.5\right.$ to $\left.+6.7 \%\right)$ of anorthosite samples from the BVLA Complex are similar to, or 415 slightly higher than, the mantle $(+5.5 \pm 0.5 \%$; Ito et al., 1987; Eiler, 2001) (Table 6). Sample 416 BVL2013-077, by comparison, has a $\delta^{18} \mathrm{O}$ value of $+4.9 \%$. Without this sample, the average 417 anorthosite whole-rock $\delta^{18} \mathrm{O}$ value is $+6.1 \pm 0.6 \%$ (all errors reported as SD), comparable to the 
418 Fiskenæsset Complex (+6.3 $\pm 0.3 \%$ ) (Polat and Longstaffe, 2014).

419 With only one exception (again BVL2013-077), BVLA Complex fresh plagioclase $\delta^{18} \mathrm{O}$ 420 values range from +5.8 to $+7.2 \%$ (avg. $+6.3 \pm 0.7 \%$ ), comparable to the Fiskenæsset Complex

421 anorthosite (plagioclase avg. $\delta^{18} \mathrm{O}=+6.4 \pm 0.5 \%$; Polat and Longstaffe, 2014). Partially altered

422 plagioclase (to epidote) from BVLA Complex anorthosite has slightly lower $\delta^{18} \mathrm{O}$ values $(+5.3$ to $423+6.0 \%$; avg. $+5.8 \pm 0.3 \%$ ) (Table 6).

\section{Discussion}

\subsection{The age of the Bad Vermilion Lake Anorthosite Complex}

Most of the spots analyzed for U-Pb dating of the two granitic samples (BVL2013-042 and BVL2013-043) were located in the oscillatory zones of the zircon grains (Figs. 9 and 10). The $\mathrm{Th} / \mathrm{U}$ ratios of these spots range from 0.47 to 1.00 , consistent with a magmatic origin (cf., Wu and Zheng, 2004). Thus, the weighted mean ${ }^{207} \mathrm{~Pb} /{ }^{206} \mathrm{~Pb}$ ages of $2716 \pm 18 \mathrm{Ma}$ and $2649 \pm 17 \mathrm{Ma}$ for these samples are interpreted as the crystallization age of the granitic rocks that intruded the BVLA Complex. In outcrop, the granitic rocks display large variations in mineralogical composition, texture and structure, suggesting multiple phases of magma intrusion. Although continuous contacts between different intrusive phases are not well exposed, the measured dates are consistent with at least two phases of granitic rock emplacement in the study area. The older $(2716 \mathrm{Ma})$ is therefore interpreted as the minimum formation age for the BVLA Complex. regression ages for the BVLA Complex. The $\mathrm{Rb}-\mathrm{Sr}$ date, however, is considered here to be 
439 unreliable given its large error and apparent younger value than the oldest date for the granitic 440 rocks that intrude the Complex. The Sm-Nd isochron age of ca. $2.74 \mathrm{Ga}$ for the BVLA Complex

441 is more reliable and probably represents its intrusion age. The latter age also, within analytical

442 error, corresponds well to previously reported dates of $\sim 2.735-2.720$ Ga for the regional

443 syn-volcanic batholiths (tonalite-diorite-gabbro) (Corfu and Davis 1992; Whalen et al. 2004;

444 Percival et al., 2006).

445

\subsection{Alteration and element mobility}

447 The rocks analyzed for this study have been metamorphosed at greenschist facies and/or undergone hydrothermal alteration. It is critical, therefore, to take account of the effects of post-magmatic alteration on the geochemistry of each lithological unit in the BVLA Complex before making petrogenetic and geodynamic interpretation based on the geochemical data.

451 Primary igneous textures are widely preserved in the BVLA Complex anorthosite, 452 leucogabbro and gabbro (Fig. 6). At some locations, however, these rocks display extensive 453 metamorphic recrystallization and calc-silicate (epidote, calcite) alteration (Fig. 6). The alteration 454 criteria of Polat and Hofmann (2003) are adopted here to assess the effects of alteration on the 455 original chemistry of the BVLA Complex. Except for three samples, all have loss-on-ignition

456 (LOI) values $<6 \mathrm{wt} . \%$, which suggests that secondary hydration or carbonation was been limited.

457 Samples having a large LOI $(>6 \%)$ and displaying different trace element patterns from other 458 samples are designated as severely altered and not considered further in the petrogenetic 459 interpretation (Table 3 and 4). All remaining samples have minor to absent Ce anomalies 
$460\left(\mathrm{Ce} / \mathrm{Ce}^{*}=0.98-1.06\right)$, indicating the absence of severe alteration (Table 3 and 4). Samples

461 containing significant quantities of calcite and epidote $(>5 \%)$ are designated as altered.

462 Anorthosite samples with minor calcite and epidote alteration $(<5 \%)$ have moderate positive Eu

463 anomalies $\left(\mathrm{Eu} / \mathrm{Eu}^{*}=1.35-4.49\right)$, whereas those containing significant epidote and carbonate

464 alteration have negative $\mathrm{Eu}\left(\mathrm{Eu} / \mathrm{Eu}^{*}=0.84-0.86\right)$ anomalies. The samples having negative Eu

465 anomalies have been designated as altered and are not considered further in the petrogenetic

466 interpretation (Table 3 and 4).

467

The anorthosite and Group 1 gabbro samples display a good correlation between $\mathrm{TiO}_{2}$,

$\mathrm{Nb}$, Sm and $\mathrm{Nd}$, on one hand, and $\mathrm{Zr}$ on the other hand, with few outliers (Fig. 14). Hence it is inferred that these element concentrations have not been significantly affected by metamorphic alteration. Similarly, REE, HFSE (Ti, Nb, Ta, Zr, Y) in most anorthosite samples, and both groups of gabbros display coherent patterns on primitive-mantle normalized diagrams (Fig. 15), indicating that these elements were also relatively immobile during post-magmatic alteration. sample (BVL2013-077), the whole-rock and fresh plagioclase oxygen isotope compositions of

475 all samples analyzed remained near-pristine magmatic values despite metamorphism. (1) The $476 \delta^{18} \mathrm{O}$ values of fresh plagioclase from the BVLA Complex anorthosite $(+6.5 \pm 0.5 \%$ compare 477 well with the compositions that typify plagioclase $\left(\delta^{18} \mathrm{O}=\sim+6.4 \%\right.$ of primary (juvenile) origin 478 (cf., Eiler, 2001). (2) The range (SD) of $\delta^{18} \mathrm{O}$ values for fresh plagioclase $( \pm 0.5 \%$, $\mathrm{n}=9)$ and 479 whole-rock $( \pm 0.6 \%, \mathrm{n}=4)$ samples is quite small (Table 6). (3) The $\delta^{18} \mathrm{O}$ values of fresh 480 plagioclase $(+6.5 \pm 0.5 \%$ ) are higher than that of altered plagioclase $(+5.8 \pm 0.3 \%$ ) (Table 6$)$. The 
481 whole-rock $\delta^{18} \mathrm{O}$ values of the BVLA Complex anorthosite are slightly higher than average 482 mantle-like composition $(+5.5 \pm 0.5 \%$; Ito et al., 1987; Eiler, 2001). This composition is 483 consistent with the classic Taylor and Epstein (1962a, 1962b) sequence of preferential 484 partitioning of ${ }^{18} \mathrm{O}$ into $\mathrm{Si}$ - and $\mathrm{Al}$-rich versus $\mathrm{Mg}$ - and Fe-rich phases during crystallization and 485 high-temperature (re)equilibration. (4) There is no correlation between $\delta^{18} \mathrm{O}$ values and the 486 alteration-sensitive Ce anomalies (Fig. 17), consistent with limited mobility of oxygen in the BVLA Complex anorthosite, at least on the scale of sampling (see Polat and Longstaffe, 2014). (5) The oxygen isotope compositions of fresh and altered plagioclase are distinct. The $\delta^{18} \mathrm{O}$ value of anorthosite sample BVL2013-77 (+4.9\%o) is lower than the rest of the 490 samples. It displays relatively strong epidotization (Supplementary Fig. 2) and plots separately

491 from other samples on many $\delta^{18} \mathrm{O}$ versus major and trace element diagrams (Fig. 17). The fresh 492 and altered plagioclase values for this sample are $+4.8 \%$ and $+5.8 \%$ respectively. We suggest

493 that the primary $\delta^{18} \mathrm{O}$ value of this sample was modified by high-temperature alteration (cf., 494 Bosch et al., 2004; Craig et al., 2011) that reset its value to $+4.8 \%$ followed by hydrothermal 495 alteration that caused the altered plagioclase to become enriched in ${ }^{18} \mathrm{O}$. Hence this sample is 496 excluded from further discussion.

497 Collectively, the whole-rock and plagioclase $\delta^{18} \mathrm{O}$ values of 'fresh' samples of the BVLA 498 Complex anorthosite are consistent with a near-pristine magmatic signatures rather than an 499 extensive metamorphic overprinting over a range of temperatures. The latter process likely 500 would have produced larger variations in oxygen isotope composition (cf., Valley, 1986; Peck 501 and Valley, 1996; Polat and Longstaffe, 2014). 


\subsection{Crustal contamination and depth of partial melting}

The anorthosite and Group 1 gabbro of the BVLA Complex display strong negative $\mathrm{Nb}$ anomalies relative to REE and LILE (Fig. 15; Tables 3 and 4). Such anomalies can be related to primary mantle source characteristics or may reflect crustal contamination (Pearce and Peate, 1995; Polat et al., 2009). There is no field evidence indicating that the BVLA Complex was emplaced into older continental crust (Ashwal et al., 1983). Large positive initial $\varepsilon N d(+2.0 \pm 1.4)$ values (Ashwal et al., 1985) for the BVLA Complex are inconsistent with its contamination by significantly older continental rocks. In addition, there are no correlations between $\mathrm{SiO}_{2}$ abundances and contamination-sensitive elements and ratios (e.g., Th, $\mathrm{Zr}, \mathrm{La}, \mathrm{Ni}, \mathrm{La} / \mathrm{Sm}$ cn, $\left.\mathrm{Nb} / \mathrm{Nb}^{*}, \mathrm{Zr} / \mathrm{Zr}^{*}\right)$. Moreover, the near-mantle whole-rock and fresh plagioclase $\delta^{18} \mathrm{O}$ values $(+6.1 \pm 0.6 \%$ and $+6.5 \pm 0.5 \%$, respectively) of the ca. 2.7 Ga BVLA Complex anorthosite are inconsistent with substantial continental crust contamination, thus suggesting a setting away from continental sources. In addition, anorthosite, leucogabbro and gabbro of the BVLA Complex share near flat to slightly enriched HREE patterns (Fig. 15). This feature is consistent with a shallow depth of partial melting of a mantle source that did not contain garnet.

\subsection{Role of fractional crystallization on cumulate processes and the emplacement of the BVLA}

\section{Complex}

Accepting that alteration and crustal contamination has had only a very small effect on the geochemistry of the BVLA Complex, these data can be used to constrain the role of fractional crystallization on its petrogenesis. Geochemical trends on $\mathrm{MgO}$ versus $\mathrm{Al}_{2} \mathrm{O}_{3}, \mathrm{CaO}, \mathrm{Fe}_{2} \mathrm{O}_{3}(\mathrm{~T})$, Ni 
523 and Co plots (Fig. 13) for anorthosite, leucogabbro and gabbro samples reflect fractionation of

524 olivine, pyroxene and plagioclase, as also observed in the Fiskenæsset Complex (Polat et al., 525 2009). In addition, low abundances of $\mathrm{MgO}, \mathrm{Ni}, \mathrm{Cr}, \mathrm{Co}$, and $\mathrm{Sc}$ in the anorthosite and 526 leucogabbro (Table 3) are consistent with the removal of olivine, clinopyroxene and/or 527 orthopyroxene prior to plagioclase accumulation (see Polat et al., 2009, 2010). These 528 geochemical characteristics indicate that the anorthosite, leucogabbro and gabbro were derived 529 from fractionated magmas.

530 Ashwal et al. (1983) suggested that the BVLA Complex was a cumulate mass from a 531 subvolcanic intrusive chamber. Similar petrogenetic processes have been proposed to explain the 532 origin of the Fiskenæsset and Naajat Kuuat complexes in Greenland and the Sittampundi 533 Complex in southern India (Polat et al., 2009; Hoffmann et al., 2012; Mohan et al., 2013; Huang 534 et al., 2014). These studies suggest that the layering in Archean anorthosite complexes indicate compositionally stratified magma chamber(s), with thick layers of late-stage crystallization of plagioclase on top and early-stage olivine-rich dunite layers at the bottom (Polat et al., 2009;

537 Hoffmann et al., 2012; Mohan et al., 2013; Huang et al., 2014). Late accumulation of calcic 538 plagioclase is consistent with differentiation of hydrous parental melts, and such a scenario is 539 commonly reported for arc-related geodynamic settings (Windley, 1995).

$540 \quad$ Ultramafic layers do not crop out in the BVLA Complex. They may lie beneath its exposed 541 level, but they may also have been removed tectonically or magmatically. For the Fiskenæsset 542 Complex, Polat et al. (2011) suggested that there was originally a 500-m thick ultramafic unit 543 (dunite, peridotite, pyroxenite, and hornblendite) at its bottom, of which $<50 \mathrm{~m}$ now remains. 
544 This suggests that more than $90 \%$ of the ultramafic rocks of the Fiskenæsset were either

545 delaminated or recycled into the mantle as a residual cumulate, or were destroyed during

546 thrusting and intrusion of granitoid rocks. Such processes may have also affected the BVLA

547 Complex.

548

549 5.5. New geochemical constraints on the geodynamic setting

550 All samples of the BVLA Complex anorthosite, leucogabbro, and Group 1 gabbro are

551 characterized by depletion of $\mathrm{Nb}$ relative to $\mathrm{Th}$ and $\mathrm{La}$. Considering that crustal contamination of

552 the BVLA Complex was likely minimal, the negative $\mathrm{Nb}$ anomalies (Fig. 15) may represent

553 mantle source characteristics. These anomalies are consistent with a subduction zone

554 (forearc-arc-backarc) signature (Pearce and Peate, 1995; Pearce, 2008; Polat et al., 2009).

555 For some elements, Group 2 gabbro is geochemically distinctive from Group 1 gabbro.

556 Group 2 gabbro is characterized by relatively low concentrations of $\mathrm{SiO}_{2}$ (Fig. 12) and $\mathrm{Zr}$ (Fig.

557 14), and display flat to positive $\mathrm{Nb}$ anomalies and strongly elevated $\mathrm{Eu}$ anomalies and $\mathrm{Ti}$

558 anomalies (Fig. 15). Compared to silicates, $\mathrm{Nb}$ partitions strongly into titanite and rutile, and

559 moderately into ilmenite and Ti-magnetite (Green and Pearson 1987; Moore et al., 1992). Thus,

560 positive $\mathrm{Ti}$ and $\mathrm{Nb}$ anomalies are likely to reflect the presence of Ti-bearing oxide minerals,

561 which is consistent with the petrographic observations (15-20\% titanite, rutile and/or ilmenite)

562 (Fig. 7). These minerals likely formed during metamorphic recrystallization of pyroxene grains;

563 they occur as small grains either in former cleavages of pyroxene grains or along some grain

564 boundaries (Fig. 7). 
Positive $\mathrm{Eu}$ anomalies indicate that plagioclase crystallization was limited before the formation of Group 2 gabbro (Fig. 15). However, except for the Eu anomalies, anorthosite, and Group 1 and Group 2 gabbro have very similar REE patterns with near flat to slightly enriched LREE patterns (Fig. 15). These similarities suggest that these rocks are cogenetic.

On the $\mathrm{Nb} / \mathrm{Nb}^{*}$ versus $\mathrm{La} / \mathrm{Sm}_{\mathrm{cn}}$ and $\mathrm{Th} / \mathrm{Nb}$ versus $\mathrm{La} / \mathrm{Nb}$ diagrams (Fig. 18), both Group 1 and Group 2 gabbro plot predominantly within the field of gabbro from Cenozoic oceanic arc settings (e.g., Aleutian Arc, Mariana Arc, Scotia Arc and Tonga Arc). In addition, they are very similar in composition to gabbro from the Semail Ophiolite in Oman (Fig. 18), which is a typical suprasubduction-zone type ophiolite (Lippard et al., 1986; Hacker et al., 1996; Dilek and Furnes 2009; Alabaster et al., 1982). Moreover, on $\delta^{18} \mathrm{O}$ versus major and trace element diagrams (Fig. 17), anorthosite from the BVLA Complex shares similar characteristics with anorthosite from the Fiskenæsset Complex, which is interpreted to have formed in an intra-oceanic arc setting (Polat et al., 2009, 2010). Therefore, based on the sum of evidence, we suggest that the BVLA Complex likely formed in an oceanic arc.

The interpretation of the BVLA Complex as the product of low-pressure partial melting at a supra-subduction zone is consistent with the experimental study of Takagi et al. (2005). They showed that at constant composition, in a low-alkali, high-alumina, arc tholeiite $\left(17 \mathrm{wt} . \% \mathrm{Al}_{2} \mathrm{O}_{3}\right)$, there is a linear relationship between plagioclase An content and water content of the melt. High-An plagioclase is the liquidus phase in such melts containing up to $5 \% \mathrm{H}_{2} \mathrm{O}$ at low pressure. The highly calcic plagioclase reported by Takagi et al. (2005) $\left(\mathrm{An}_{90}\right)$ is comparable with the peak anorthite $(\mathrm{An})$ content reported for BVLA anorthosite $\left(\mathrm{An}_{81}\right)$ (Ashwal et al., 1983). 


\subsection{Petrogenesis of intrusive granitic rocks associated with the BVLA Complex}

The granitic rocks display near flat to slightly fractionated REE patterns with low $\mathrm{La} / \mathrm{Yb}$ (2.4-3.2) and high $\mathrm{Yb}_{\mathrm{cn}}(65.3-95.3)$ (Fig. 16). These geochemical characteristics suggest that the granitic rocks formed by partial melting of a mafic source at shallow depths, probably the lower crust, without garnet residue in the source. The presence of negative $\mathrm{Eu}$ and $\mathrm{Sr}$ anomalies in the granitic rocks (Fig. 16) reflects a plagioclase residue in the source, and thus melting at pressures lower than the plagioclase stability field ( $<32 \mathrm{~kb}$, Lindsley, 1968). The low Sr (59-128 ppm) and high Y (95-168 ppm) abundances and correspondingly low $\mathrm{Sr} / \mathrm{Y}(0.40-1.25)$ are consistent with retention of plagioclase in the source (Table 5). Additionally, all samples exhibit strong depletion of $\mathrm{Nb}$, Ta and $\mathrm{Ti}$ on the primitive mantle-normalized diagram (Fig. 16), which may be attributed to rutile in the residue or melting of mafic crust in a thickened arc (Martin et al., 2005; Nagel et al., 2012).

The Bad Vermilion Lake granitic rocks possess high $\mathrm{SiO}_{2}\left(\sim 77\right.$ wt.\%), $\mathrm{Fe}_{2} \mathrm{O}_{3}(\mathrm{~T}) / \mathrm{MgO}$ ratios (28 to 55) and HFSE (>100 times chondrite), and low $\mathrm{CaO}, \mathrm{Sr}, \mathrm{Ba}$ and $\mathrm{Eu}$ contents (Table 5). These features are similar to those of A-type granites (Whalen et al., 1987). On plots of Zr versus $10,000 \times \mathrm{Ga} / \mathrm{Al}$ and $\mathrm{Nb}$ versus $10,000 \times \mathrm{Ga} / \mathrm{Al}$ (Whalen et al., 1987), the Bad Vermilion Lake granitic rocks plot within the field of A-type granites (Supplementary Fig. 3).

A-type granites are generally considered to form in extensional settings (Bonin, 2007; Dostal et al., 2015 and references therein). They can be further divided into $A_{1}$ and $A_{2}$ chemical subgroups (Eby, 1992). A -type granites have certain geochemical characteristics similar to those observed for oceanic-island basalts (OIB) and thus their sources are considered to be from within 
607

608

609

610

611

612

613

614

615

616

617

618

619

620

621

622

623

624

625

626

627

intraplate settings (Eby, 1992). In contrast, $A_{2}$-type granites are similar to rocks from continental

crusts or island arcs developed at convergent plate margins (Eby, 1992). It has been suggested

that the arc geochemical signature of $\mathrm{A}_{2}$-type granites is related to fluids released during subduction (Li et al., 2012).

The Neoarchean Bad Vermilion Lake granitic rocks reported in this study plot in the field of $\mathrm{A}_{2}$ subgroup and overlap with IAB field, consistent with an arc setting (Supplementary Fig. 4).

Thus, we suggest that the Bad Vermilion Lake granitic rocks formed in a post-collisional extensional setting following emplacement of the BVLA Complex in a magmatic arc (Fig. 19).

\subsection{Geochemistry of Archean rocks and plate tectonics}

A detailed discussion of Archean igneous petrogenesis and tectonics is beyond the scope and objectives of this study. Interested readers are referred to Polat et al. (2015) for a comparison between mobilist, uniformitarian (i.e., Phanerozoic-like plate tectonics) and fixist, non-uniformitarian (i.e., gravity-driven sinking, sagduction, dripping, delamination, diapiric rising, crustal overturn, and heat pipe processes) models proposed for the Archean Earth. The non-uniformitarian models cannot explain the occurrence of similar field relationships (e.g., cross-cutting relationships, unconformities, tectonically juxtaposed crustal blocks), lithological associations (e.g., ophiolites, volcanic suites, mélanges, granitoid rocks), and structural (e.g., asymmetric folds, strike-slip, normal and reverse faults) and geochemical (e.g., HFSE, REE, LILE, transition metal systematics) characteristics in both the Archean and Phanerozoic rock records (see de Wit, 1998; Furnes et al., 2007, 2013, 2015; Burke, 2011; Kisters et al., 2012; 
628 Percival et al., 2012; Kusky et al., 2013; Santosh et al., 2013; Backeberg et al., 2014; Nutman et 629 al., 2015). The non-uniformitarian models have no Archean field analogs. associations are controlled mainly by tectonics, reflecting the physical and chemical processes associated with different tectonic settings (e.g., mid-ocean ridge, arc, forearc, continental rift). The Archean and Phanerozoic geological records have similar igneous (e.g., basalt, andesite, 634 dacite, rhyolite, granite, granodiorite, diorite, gabbro, dunite, peridotite, and so on), metamorphic 635 (e.g., greenschist, amphibolite, granulite) and sedimentary (conglomerate, sandstone, shale, 636 carbonate, chert) rock types, and structures, indicating that geological processes operated in both 637 eons are broadly similar.

The trace element compositions of igneous rocks occurring in different tectonic settings are 639 distinct in terms their REE, LILE, and HFSE systematics (Sun and McDonough, 1989; Hofmann, 1997; Polat and Kerrich, 2006; Pearce, 2008), differences that stem from the physical and chemical processes involved in the genesis of these rocks in a particular tectonic environment.

642 Because certain groups of elements (e.g., HFSE, REE, LREE, transition metals) behave 643 consistently in petrogenesis, including processes affecting source composition, residual 644 mineralogy, partial melting, magma differentiation, metasomatism and hybridization, these 645 elements are expected to have had similar behavior throughout Earth's history (Polat and Kerrich, 646 2006).

647 Although the Archean Eon had higher mantle temperatures than its Phanerozoic 648 counterpart (see Herzberg et al., 2010 and references therein), Archean volcanic rocks share the 
649

650

651

652

653

654 southwestern Superior Province. Given the presence of polyphase deformation and

655

656 657 their geodynamic setting.

658

659

660

661

662

663

664

665

666

667

668

669

trace element characteristics of Phanerozoic equivalents (see Szilas et al., 2012, 2013a, 2013b;

Polat, 2013), suggesting that uniformitarian geochemical behavior also prevailed in the Archean

despite counter arguments (e.g., Bédard, 2006). Accordingly, we suggest that the geochemical

characteristics of the BVLA Complex and the spatially associated granitic rocks represent

regional-scale tectonic processes operated at a Neoarchean convergent margin in the metamorphism in Archean terranes, however, we continue to caution that the trace element systematics of Archean rocks should be used in conjunction with field characteristics to constrain

\section{Conclusions}

On the basis of new field, petrographic, $\mathrm{U}-\mathrm{Pb}$ zircon age, whole-rock major and trace element, and whole-rock and plagioclase mineral oxygen isotope data, we reach the following conclusions concerning the origin of the Neoarchean BVLA Complex and the spatially associated granitic rocks:

1. Zircon $\mathrm{U}-\mathrm{Pb}$ ages from the intruding granitic rocks suggest a minimum age of $2716 \pm 18 \mathrm{Ma}$ for the BVLA Complex. Zircon ages indicate that the granitic rocks were emplaced as multiple batches of magma between 2716 and 2649 Ma.

2. Although the BVLA Complex underwent greenschist-facies metamorphism, its original geochemical composition was not affected significantly. The geochemical and oxygen isotopic data do not indicate substantial crustal contamination of the BVLA Complex. 
670

671

672

673

674

675

676

677

678

679

680

681

682

683

684

685

686

687

688

689

690

3. The parental magmas of the anorthosite, leucogabbro and gabbro in the BVLA Complex originated from partial melting of a shallow mantle source. Trends of $\mathrm{Zr}$ and $\mathrm{MgO}$ versus immobile major and trace elements indicate that the concentrations of most elements were controlled by fractional crystallization involving the removal and accumulation of olivine, orthopyroxene, clinopyroxene, amphibole and plagioclase.

4. The trace element systematics of the anorthosite, leucogabbro, and gabbro of the BVLA Complex and the oxygen isotope systems of its anorthosite are consistent with an intra-oceanic subduction zone geodynamic setting. On the basis of these geochemical characteristics, the BVLA Complex is interpreted as a remnant of a Neoarchean oceanic island arc.

5. Geochemical data indicate that the granitic rocks intruded into the BVLA Complex are $\mathrm{A}_{2}$-type. We suggest that they formed in a post-collisional, extensional setting following formation of the BVLA Complex in the arc.

\section{Acknowledgements}

This research was supported by NSERC grants to A. Polat and F.J. Longstaffe, and made possible, in part, through release time provided by the Canada Research Chairs Program. Constructive comments by one anonymous reviewer and M.R. Mohan resulted in significant improvements to the paper. We acknowledge and thank J.C. Barrette for assistance with the trace element analyses, S. Lackie for assistance with the SEM analyses, and N. Naderi for assistance with the oxygen isotopic analyses. We thank Dr. Y. Eyuboglu and Dr. M. Santosh for the invitation to join this special issue. This is Laboratory for Stable Isotope Science (LSIS) 
691 Contribution \#330.

692 References

693 Alabaster, T., Pearce, J.A., Malpas, J., 1982. The volcanic stratigraphy and petrogenesis of the 694 Oman ophiolite complex. Contributions to Mineralogy and Petrology 81, 168-183.

695 Allard, G.O., 1970. The Dore Lake complex, Chibougamau, Quebec-a metamorphosed 696 Bushveld-type layered intrusion. In Symposium on the Bushveld igneous complex and other 697 layered intrusions, Editors: JL Visser and G. Von Gruenewaldt. Geological Society of South Africa, pp. 477-491.

Ashwal, L.D., Wooden, J.L., Phinney, W.C., Morrison, D.A., 1985. Sm-Nd and Rb-Sr isotope systematics of an Archean anorthosite and related rocks from the Superior Province of the Canadian Shield. Earth and Planetary Science Letters 74, 338-346.

Ashwal, L.D., Jacobsen, S.B., Myers, J.S., Kalsbeek, F., Goldstein, S.J., 1989. Sm-Nd Age of the Fiskenæsset Anorthosite Complex, West Greenland. Earth and Planetary Science Letter 91, 261-270.

Ashwal, L.D., 1993. Anorthosites. Minerals and Rocks Series 21. Springer-Verlag, Berlin, 422 pp.

Ashwal, L.D., Myers, J.S., 1994. Archean anorthosites. Archean Crustal Evolution. Elsevier, Amsterdam, 315-355.

Ashwal, L.D., Phinney, W.C., Morrison, D.A., Wooden, J.L., 1982. Underplating of Archean continents: evidence from the Bad Vermillion Lake Anorthosite Complex, Ontario. In Lunar and Planetary Science Conference 13, 20-21. 
Ashwal, L.D., 1981. The Bad Vermilion Lake Anorthosite Complex, Ontario: Sr and Nd isotopic evidence for depleted Archean mantle. Abstract with Program, Geological Society of America 13, 399.

Ashwal, L.D., 2004. Origin of anorthosites: petrological and tectonic considerations. Transactions of American Geophysical Union (Eos) 85, 514.

Ashwal, L.D., Morrison, D.A., Phinney, W.C., Wood, J., 1983. Origin of Archean anorthosites: evidence from the Bad Vermilion Lake Anorthosite Complex, Ontario. Contributions to Mineralogy and Petrology 82, 259-273.

Ashwal, L.D., 2010. The temporality of anorthosites. The Canadian Mineralogist 48, 711-728.

Backeberg, N.R., Rowe, C.D., van Hinsberg, V.J., Bellefroid, E.J., 2014. Structural and metamorphic evidence for Mesoarchaean subduction in the Finlayson Lake greenstone belt, Superior Province, Ontario. Precambrian Research 249, 100-114.

Beakhouse, G.P., 1991. Winnipeg River subprovince. In: Thurston, P.C., Williams, H.R., Sutcliffe, R.H., Stott, G.M. (Eds.), Geology of Ontario. Ontario Geological Survey Special Volume 4, Pt. 1, pp. 279-301.

Bédard, J.H., 2006. A catalytic delamination-driven model for coupled genesis of Archaean crust and sub-continental lithospheric mantle. Geochimica et Cosmochimica Acta 70, 1188-1214.

Bédard, J.H., Leclerc, F., Harris, L.B., Goulet, N., 2009. Intra-sill magmatic evolution in the Cumming Complex, Abitibi greenstone belt: Tholeiitic to calc-alkaline magmatism recorded in an Archean subvolcanic conduit system. Lithos 111, 47-71. 
Berger, J., Diot, H., Lo, K., Ohnenstetter, D., Femenias, O., Pivin, M., Demaiffe, D., Bernard, A., Charlier, B., 2013. Petrogenesis of Archean PGM-bearing chromitites and associated ultramafic-mafic-anorthositic rocks from the Guelbel Azib layered complex (West African craton, Mauritania). Precambrian Research 224, 612-628.

Bhaskar Rao, Y.J., Chetty, T.R.K., Janardhan, A.S., Gopalan, K., 1996. Sm-Nd and Rb-Sr ages and $\mathrm{P}-\mathrm{T}$ history of the Archean Sittampundi and Bhavani layered meta-anorthosite complexes in the Cauvery shear zone, South India: evidence for Neoproterozoic reworking of Archean crust. Contributions to Mineralogy and Petrology 125, 237-250.

Blackburn, C.E., John, G.W., Ayer, J., Davis, D.W., 1991. Wabigoon Subprovince. In: Thurston, P.C., Williams, H.R., Sutcliffe, R.H., Stott, G.M. (Eds.), Geology of Ontario. Ontario Geological Survey Special Volume 4, Pt. 1, pp. 303-381.

Bosch, D., Jamais, M., Boudier, F., Nicolas, A., Dautria, J.M., Agrinier, P., 2004. Deep and high-temperature hydrothermal circulation in the Oman ophiolite-petrological and isotopic evidence. Journal of Petrology 45(6), 1181-1208.

Bonin, B., 2007. A-type granites and related rocks: evolution of a concept, problems and prospects. Lithos 97, $1-29$.

Borthwick, J., Harmon, R.S., 1982. A note regarding ClF3 as an alternative to BrF5 for oxygen isotope analysis. Geochimica et Cosmochimica Acta 46, 1665-1668.

Burke, K., 2011. Plate tectonics, the Wilson cycle, and mantle plumes: geodynamics from the top. Annual Review of Earth and Planetary Sciences 39, 1-29.

Card, K.D., Ciesielski, A., 1986. Subdivisions of the Superior Province of the Canadian Shield. 
Card, K.D., Poulsen, K.H., 1998. Geology and mineral deposits of the Superior Province of the Canadian shield. Chapter 2 in Geology of the Precambrian Superior and Grenville Provinces and Precambrian Fossils in North America. In: Lucas, S. (Coord.), Geological Survey of Canada Geology of Canada 7, pp. 13-194.

Clayton, R.N., Mayeda, T.K., 1963. The use of bromine pentafluoride in the extraction of $43-52$.

761

Corfu, F., Davis, D.W., 1992. A U-Pb geochronological framework for the western Superior Province, Ontario. In: Thurston, P.C., Williams, H.R., Sutcliffe, R.H., Stott, G.M. (Eds.), Geology of Ontario. Ontario Geological Survey Special Volume 4, Pt. 2, pp. 1335-1346.

Corfu, F., Stott, G.M., 1993. Age and petrogenesis of two late Archean magmatic suites, northwestern Superior Province, Canada: zircon $\mathrm{U}-\mathrm{Pb}$ and $\mathrm{Lu}-\mathrm{Hf}$ isotopic relations. Journal of Petrology 34, 817-838.

Corfu, F., Stott, G.M., Breaks, F.W., 1995. U-Pb geochronology and evolution of the English River subprovince, an Archean low P-high T metasedimentary belt in the Superior Province. Tectonics 14, 1220-1233.

Corkery, M.T., Davis, D.W., Lenton, P.G., 1992. Geochronological constraints on the development of the Cross Lake greenstone belt, northwest Superior Province, Manitoba. Canadian Journal of Earth Sciences, 29(10), 2171-2185.

773 Cruden, A.R., Davis, D.W., Menard, T., Robin, P.Y.R., 1997. Structural and geochronological 
relationships between the Winnipeg River and Wabigoon Subprovinces: implications for the terrane accretion model. In: Harrap, R.M., Helmstaedt, H. (Eds.), Western Superior Transect Second Annual Workshop. Lithoprobe Report 63, pp. 18-26.

Cruden, A.R., Davis, D.W., Melnyk, M., Robin, P.Y.R., Menard, T., 1998. Structural and geochronological observations at Kenora: implications for the style and timing of deformation during the Kenoran orogeny, northwestern Ontario. In: Harrap, R.M., Helmstaedt, H. (Eds.), Western Superior Transect Second Annual Workshop. Lithoprobe Report 65, pp. 54-62.

Davis, D.W., Sutcliffe, R.H., Trowell, N.F., 1988. Geochronological constraints on the tectonic evolution of a late Archean greenstone belt, Wabigoon subprovince, northwest Ontario. Precambrian Research 39, 171-191.

Davis, D.W., Pezzuto, F., Ojakangas, R.W., 1990. The age and provenance of metasedimentary rocks in the Quetico subprovince, Ontario, from single zircon analyses: implications for Archean sedimentation and tectonics in the Superior Province. Earth and Planetary Science Letters 99, 195-205.

Davis, D.W., Smith, P.M., 1991. Archean gold mineralization in the Wabigoon subprovince, a product of crustal accretion: evidence from $\mathrm{U}-\mathrm{Pb}$ geochronology in the Lake of the Woods area, Superior Province, Canada. Journal of Geology 99, 337-353.

Davis, D.W., 1996. Provenance and depositional age constraints on sedimentation in the western Superior transect area from U-Pb ages of zircons. In: Harrap, R.M., Helmstaedt, H. (Eds.), Western Superior Transect Second Annual Workshop. Lithoprobe Report 53, pp. 18-23. 
Davis, D.W., 1998. Speculations on the formation and crustal structure of the Superior province from U-Pb geochronology. In: Harrap, R.M., Helmstaedt, H. (Eds.), Western Superior Transect Second Annual Workshop. Lithoprobe Report 65, pp. 21-28.

de Wit, M.J., 1998. On Archean granites, greenstones, cratons, and tectonics: does the evidence demand a verdict? Precambrian Research 91, 181-226.

Dilek, Y., Furnes, H., 2009. Structure and geochemistry of Tethyan ophiolites and their petrogenesis in subduction rollback systems. Lithos 113, 1-20.

Dilek, Y., Furnes, H., 2014. Ophiolites and their origins. Elements 10, 93-100.

Dostal, J., Owen, V., Shellnutt, G., Keppie, D., Gerel, O., Corney, R., 2015. Petrogenesis of the Triassic Bayan-Ulan alkaline granitic pluton in the North Gobi rift of central Mongolia: Implications for the evolution of Early Mesozoic granitoid magmatism in the Central Asian Orogenic Belt. Journal of Asian Earth Sciences 109, 50-62.

Eby, G.N., 1992. Chemical subdivision of the A-type granitoids: petrogenetic and tectonic implications. Geology 20, 641-644.

Eiler, J.M., 2001. Oxygen isotope variations in basaltic lavas and upper mantle rocks. In: Valley, J.W., Cole, D.R. (Eds.), Stable Isotope Geochemistry. In: Reviews in Mineralogy and Geochemistry, vol. 43. Mineralogical Society of America, Washington, pp. 319-364.

Fralick, P., 1997. Neoarchean evolution of the Wabigoon Subprovince: evidence from the sedimentary record. In: Harrap, R.M., Helmstaedt, H. (Eds.), 1999 Western Superior Transect Fifth Annual Workshop. Lithoprobe Report 63, Lithoprobe Secretariat, University of British Columbia, pp. 97-99. 
816 Fralick, P., Davis, D.W., 1999. The Seine-Couchiching problem revisited: sedimentology, 817 geochronology and geochemistry of sedimentary units in the Rainy Lake and Sioux Lookout areas. In: Harrap, R.M., Helmstaedt, H.H. (Eds.), 1999 Western Superior Transect Fifth Annual Workshop. Lithoprobe Report 70, Lithoprobe Secretariat, University of British Columbia, pp. 66-75.

821

822

823

824

825

826

827

828

829

830

831

832

Furnes, H., de Wit, M., Staudigel, H., Rosing, M., Muehlenbachs, K., 2007. A vestige of Earth’s oldest ophiolite. Science 315, 1704-1707.

Furnes, H., de Wit, M.J., Robins, B., 2013. A review of new interpretations of the tectonostratigraphy, geochemistry and evolution of the Onverwacht Suite, Barberton Greenstone Belt, South Africa. Gondwana Research 23, 403-428.

Furnes, H., Dilek, Y., de Wit, M., 2015. Precambrian greenstone sequences represent different ophiolite types. Gondwana Research 27, 649-685.

Gower, C.F., Clifford, P.M., 1981. The structural geometry and geological history of Archean rocks at Kenora, northwestern Ontario; a proposed type area for the Kenoran Orogeny. Canadian Journal of Earth Science 18, 1075-1091.

Green, T.H., Pearson, N.J., 1987. An experimental study of $\mathrm{Nb}$ and Ta partitioning between Ti-rich minerals and silicate liquids at high pressure and temperature. Geochimica et Cosmochimica Acta 51, 55-62.

Grimes, C.B., Ushikubo, T., John, B.E., Valley, J.W., 2011. Uniformly mantle-like $\delta^{18} \mathrm{O}$ in zircons from oceanic plagiogranites and gabbros. Contributions to Mineralogy and Petrology 161, 13-33. 
837 Hacker, B.R., Mosenfelder, J.L., Gnos, E., 1996. Rapid emplacement of the Oman ophiolite, 838 thermal and geochronological constraints. Tectonics 15, 1230-1247.

839 Halama, R., Waight, T., Markl, G., 2002. Geochemical and isotopic zoning patterns of 840 plagioclase megacrysts in gabbroic dykes from the Gardar Province, South Greenland: implications for crystallisation processes in anorthositic magmas. Contributions to Mineralogy and Petrology 144, 109-127.

Hart, S.R., Davis, G.L., 1969. Zircon U-Pb and whole-rock Rb-Sr ages and early crustal development near Rainy Lake, Ontario. Geological Society of America Bulletin 80, 595-616.

Henry, P., Stevenson, R., Gariepy, C., 1998. Late Archean mantle composition and crustal growth in the western Superior Province of Canada: Neodymium and lead isotopic evidence from the Wawa, Quetico, and Wabigoon subprovinces. Geochimica et Cosmochimica Acta $62,143-157$.

Henry, P., Stevenson, R., Laribi, Y., Gariepy, C., 2000. Nd isotopic evidence for Early to Late Archean (3.4-2.7 Ga) crustal growth in the Western Superior Province (Ontario, Canada). Tectonophysics 322, 135-151.

Herzberg, C., Condie, K., Korenaga, J., 2010. Thermal history of the Earth and its petrological expression. Earth and Planetary Science Letters 292, 79-88.

Hofmann, A.W., 1997. Mantle geochemistry: the message from oceanic volcanism. Nature 385, 219-229.

Hofmann, A.W., 1988. Chemical differentiation of the Earth: the relationship between mantle, continental crust, and oceanic crust. Earth and Planetary Science Letters 90, 297-314. 
858

859

860

861

862

863

864

865

866

867

868

869

870

871

872

873

874

875

876

877

878

Hoffmann, J.E., Svahnberg, H., Piazalo, S., Schersten, A., Munker, C., 2012. The geodynamic evolution of Mesoarchean anorthosite complexes inferred from the Naajat Kuuat Complex, Southern West Greenland. Precambrian Research 196-197, 149-170.

Hu, Z., Liu, Y., Gao, S., Liu, W., Zhang, W., Tong, X., Yang, L., 2012. Improved in situ Hf isotope ratio analysis of zircon using newly designed $\mathrm{X}$ skimmer cone and jet sample cone in combination with the addition of nitrogen by laser ablation multiple collector ICP-MS. Journal of Analytical Atomic Spectrometry 27, 1391-1399.

Hubregtse, J. J. M. W., 1980. The Archean Pilcwitonei granulite domain and its position at the margin of the northwestern Superior Province (Manitoba). Manitoba Dept. of Energy and Mines, Geological Survey, Geology Paper GP8O-3, 16 pp.

Ito, E., White, W.M., Goepel, C., 1987. The O, Sr, Nd and Pb isotope geochemistry of MORB. Chemical Geology 62, 157-176.

Jenner, G.A., Longerich, H.P., Jackson, S.E., Fryer, B.J., 1990. ICP-MS; a powerful tool for high-precision trace-element analysis in earth sciences; evidence from analysis of selected U. S. G. S. Reference samples. Chemical Geology 83, 133-148.

Kisters, A.F.M., van Hinsberg, V.J., Szilas, K., 2012. Geology of an Archaean accretionary complex - the structural record of burial and return flow in the Tartoq Group of South West Greenland. Precambrian Research 220-221, 107-122.

Kusky, T.M., Windley, B.F., Safonova, I., Wakita, K., Wakabayashi, J., Polat, A., Santosh, M., 2013. Recognition of plate stratigraphy in accretionary orogens through Earth history: A record of 3.8 billion years of sea floor spreading, subduction, and accretion. Gondwana 
880

881

882

883

884

885

886

887

888

889

890

891

892

893

894

895

896

897

898

899

Leclerc, F., Bédard, J.H, Harris, L.B., McNicoll, V.J., Goulet, N., Roy, P., Houle, P., 2011.

Tholeiitic to calc-alkaline cyclic volcanism in the Roy Group, Chibougamau area, Abitibi Greenstone Belt — revised stratigraphy and implications for VHMS exploration. Canadian Journal of Earth Sciences 48, 661-694.

Li, H., Ling, M.X., Li, C.Y., Zhang, H., Ding, X., Yang, X.Y., Fan, W.M., Li, Y.L., Sun, W.D., 2012. A-type granite belts of two chemical subgroups in central eastern China: indication of ridge subduction. Lithos 150, 26-36.

Lindsley, D. H., 1968. Melting relations of plagioclase at high pressures. Origin of anorthosite and related rocks (YW Isachsen, ed.), Memoir 18, 39-46.

Lippard, S.J., Shelton, A.W., Gass, I.G., 1986. The Ophiolite of Northern Oman. Blackwell Scientific Publications, Oxford, 178 pp.

Liu, Y.S., Hu, Z.C., Zong, K.Q., Gao, C.G., Gao, S., Xu, J. and Chen, H.H., 2010. Reappraisement and refinement of zircon $\mathrm{U}-\mathrm{Pb}$ isotope and trace element analyses by LA-ICP-MS. Chinese Science Bulletin 55, 1535-1546.

Ludwig, K.R., 2003. ISOPLOT 3.00: A Geochronological Toolkit for Microsoft Excel. Berkeley Geochronology Center, California, Berkeley, 39 pp.

MacKasey W.O., Blackburn C.E., Trowell N.F., 1974. A regional approach to the WabigoonQuetico belts and its bearing on exploration in northwestern Ontario. Ontario Division of Mines Miscellaneous Publication 58 pp 29.

Martin, H., Smithies, R.H., Rapp, R., Moyen, J.F., Champion, D., 2005. An overview of adakite, 
tonalite-trondhjemite-granodiorite (TTG), and sanukitoid: relationships and some implications for crustal evolution. Lithos 79, 1-24.

902

903

904

905

906

907

908

909

910

911

912

913

914

915

916

917

918

919

920

Melnyk, M.J., Cruden, A.R., Davis, D.W., 2000. Structural geometry and deformational chronology of the Kenora gneisses. In: Harrap, R.M., Helmstaedt, H. (Eds.), Western Superior Transect Second Annual Workshop. Lithoprobe Report 77, pp. 82-89.

Mohan, M.R., Satyanarayanan, M., Santosh, M., Sylvester, P.J., Tubrett, M., Lam, R., 2013. Neoarchean suprasubduction zone arc magmatism in southern India: Geochemistry, zircon $\mathrm{U}-\mathrm{Pb}$ geochronology and $\mathrm{Hf}$ isotopes of the Sittampundi Anorthosite Complex. Gondwana Research 23, 539-557.

Moore, R.O., Griffin, W.L., Gurney, J.J., Ryan, C.G., Cousens, D.R., Sie, S.H., Suter, G., 1992. Trace element geochemistry of ilmenite megacrysts from the Monastery kimberlite, South Africa. Lithos 29, 1-18.

Morrison, D.A., Haskin, L., Qui, Y.Z., Phinney, W.C., MacZuga, D., 1985. Alteration in Archean anorthosite complexes. In Lunar and Planetary Science Conference Vol. 16, $589-590$.

Morrison, D.A., Phinney, W.C., Maczuga, D.E., 1987. Archean anorthosites: Constraints on the accumulation process. Lunar and Planetary Institute Science Conference Abstracts Vol. 18.

Mortensen, J.K., 1993, U-Pb geochronology of the eastern Abitibi subprovince: Part 1. Chibougamau-Matagami-Joutel region: Canadian Journal of Earth Sciences, v. 30, p. 11-28.

Nagel, T.J., Hoffmann, J.E., Münker, C., 2012. Generation of Eoarchean tonalite-trondhjemitegranodiorite series from thickened mafic arc crust. Geology 40, 375-378. 
921 Nutman, A.P., Bennett, V.C., Friend, C.R.L., Yi, K., Lee, S.R., 2015. Mesoarchaean collision of

922

923

924

925

926

927

928

929

930

931

932

933

934

935

936

937

Kapisilik terrane 3070 Ma juvenile arc rocks and $>3600$ Ma Isukasia terrane continental crust

(Greenland). Precambrian Research 258, 146-160.

Peck, W.H., Valley, J.W., 1996. The Fiskenæsset Anorthosite complex: stable isotope evidence for shallow emplacement into Archean oceanic crust. Geology 24, 523-526.

Pearce, J.A., 2008. Geochemical fingerprinting of oceanic basalts with applications to ophiolite classification and the search for Archean oceanic crust, Lithos 100, 14-48.

Pearce, J.A., Peate, D.W., 1995. Tectonic implications of the composition of volcanic arc magmas. Annual Review of Earth and Planetary Sciences 23, 251-286.

Percival, J.A., 1998. Structural transect of the central Wabigoon subprovince between the Sturgeon Lake and Obonga Lake greenstone belts. In: Current Research 1998-C, Geological Survey of Canada, pp. 127-136.

Percival, J.A., Bailes, A.H., McNicoll, V., 2001. Mesoarchean western margin of the Superior craton in the Lake Winnipeg area, Manitoba. In: Current Research 2001-C16, Geological Survey of Canada, $19 \mathrm{p}$.

Percival, J.A., Bailes, A.H., McNicoll, V., 2002. Mesoarchean breakup, Neoarchean accretion in the western Superior craton, Lake Winnipeg, Canada. Geological Association of Canada Field Trip B3 Guidebook, 42 pp.

Percival, J.A., Sanborn-Barrie, M., Stott, G., Helmstaedt, H., Skulski, T., White, D.J. 2006. Tectonic evolution of the Western Superior Province from NATMAP and LITHOPROBE studies: Canadian Journal of Earth Sciences 43, 1085-1117. 
942

943

944

945

946

947

948

949

950

951

952

953

954

955

956

957

958

959

960

961

962

Percival, J.A., Skulski, T., Sanborn-Barrie, M., Stott, G.M., Leclair, A.D., Corkery, M.T., Boily, M., 2012. Geology and tectonic evolution of the Superior Province, Canada. In Tectonic Styles in Canada: The Lithoprobe Perspective Edited by J.A. Percival, F.A. Cook and R.M. Clowes. Geological Association of Canada Special Paper 49, pp. 321-378.

Phinney, W.C., Donald A.M., David E.M., 1988. Anorthosites and related megacrystic units in the evolution of Archean crust. Journal of Petrology 29, 1283-1323.

Polat, A., 2012. Growth of Archean continental crust in oceanic island arcs. Geology 40, $383-384$.

Polat, A., 2013. Geochemical variations in Archean volcanic rocks, southwestern Greenland: Traces of diverse tectonic settings in the early Earth. Geology 41, 379-380.

Polat, A., Hofmann, A.W., 2003. Alteration and geochemical patterns in the 3.7-3.8 Ga Isua greenstone belt, West Greenland. Precambrian Research 126, 197-218.

Polat, A., Appel, P.W.U., Fryer, B., Windley, B., Frei, R., Samson. I.M., Huang, H., 2009. Trace element systematic of the Neoarchean Fiskenæsset anorthosite complex and associated metavolcanic rocks, SW Greenland: Evidence for a magmatic arc origin. Precambrian Research 175, 87-115.

Polat, A., Frei, R., Scherstén, A., Appel, P.W., 2010. New age (ca. 2970Ma), mantle source composition and geodynamic constraints on the Archean Fiskenæsset anorthosite complex, SW Greenland. Chemical Geology 277, 1-20.

Polat, A., Fryer, B.J., Appel, P.W., Kalvig, P., Kerrich, R., Dilek, Y., Yang, Z., 2011. Geochemistry of anorthositic differentiated sills in the Archean ( 2970Ma) Fiskenæsset 
Complex, SW Greenland: Implications for parental magma compositions, geodynamic setting, and secular heat flow in arcs. Lithos 123, 50-72.

Polat, A., Fryer, B.J., Samson, I.M., Weisener, C., Appel, P.W., Frei, R., Windley, B.F., 2012. Geochemistry of ultramafic rocks and hornblendite veins in the Fiskenæsset layered anorthosite complex, SW Greenland: Evidence for hydrous upper mantle in the Archean. Precambrian Research 214, 124-153.

Polat, A., Longstaffe, F.J., 2014. A juvenile oceanic island arc origin for the Archean (ca. 2.97 Ga) Fiskenæsset Anorthosite Complex, southwestern Greenland: Evidence from oxygen isotopes. Earth and Planetary Science Letters 396, 252-266.

Polat, A., Wang, L., Appel, P.W.U., 2015. A review of structural patterns and melting processes in the Archean craton of West Greenland: Evidence for crustal growth at convergent plate margins as opposed to non-uniformitarian models. Tectonophysics, http://dx.doi.org/10.1016/j.tecto.2015.04.006.

Rao, C.D., Santosh, M., Sajeev, K., Windley, B.F., 2013. Chromite-silicate chemistry of the Neoarchean Sittampundi Complex, southern India: Implications for subduction-related arc magmatism. Precambrian Research 227, 259-275.

Riccio, L., 1981, Geology of the northeastern portion of the Shawmere anorthosite complex, District of Sudbury: Ontario Geological Survey Open File Report 5338, 113 pp.

Rollinson, H., Claire R., Brian W., 2010. Chromitites from the Fiskenæsset Anorthositic Complex, West Greenland: clues to late Archean mantle processes. Geological Society, London, Special Publications 338, 197-212. 
984 Sanborn-Barrie, M., Skulski, T., Parker, J.R., 2001. Three hundred million years of tectonic history recorded by the Red Lake greenstone belt, Ontario. In: Current Research 2001-C19, Geological Survey of Canada 19 pp.

Santosh, M., Shaji, E., Tsunogae, T., Ram Mohan, M., Satyanarayanan, M., Horie, K., 2013. Suprasubduction zone ophiolite from Agali hill: Petrology, zircon SHRIMP U-Pb geochronology, geochemistry and implications for Neoarchean plate tectonics in southern India. Precambrian Research 231, 301-324.

991

992

993

994

995

996

997
Souders, A.K., Sylvester, P.J., Myers, J.S., 2013. Mantle and crustal sources of Archean anorthosite: a combined in situ isotopic study of $\mathrm{Pb}-\mathrm{Pb}$ in plagioclase and $\mathrm{Lu}-\mathrm{Hf}$ in zircon. Contributions to Mineralogy and Petrology 165, 1-24.

Stott, G.M., Corfu, F., 1991. Uchi Subprovince. In: Thurston, P.C., Williams, H.R., Sutcliffe, R.H., Stott, G.M. (Eds.), Geology of Ontario. Ontario Geological Survey Special Volume 4, Pt. 1, pp. 145-238.

Stott, G.M., 1997. The Superior Province, Canada. In: de Wit, M.J., Ashwal, L.D. (Eds.), Greenstone Belts. Oxford Monographs Geology and Geophysics, vol. 35. Oxford, Clarendon, pp. $480-507$.

Sun, S.S., McDonough, W.F., 1989. Chemical and isotopic systematics of oceanic basalts: implications for mantle composition and processes. In: Saunders, A.D., Norry, M.J. (Eds.), Magmatism in the Ocean Basins. Geological Society of London Special Publication 42, pp. 313-345. 
1004

1005

1006

1007

1008

1009

1010

1011

1012

1013

1014

1015

1016

1017

1018

1019

1020

1021

1022

1023

1024

Szilas, K., Hoffmann, J.E., Schersten, A., Kokfelt, T.F., Münker, C., 2013a. Archean andesite petrogenesis: Insights from the Gradefjord Supracrustal Belt, southern West Greenland. Precambrian Research 235, 1-15.

Szilas, K., Hoffmann, J.E., Schersten, A., Rosing, M., Windley, B.F., Kokfelt, T.F., Keulen, N., van Hinsberg, V.J., Naraa, T., Frei, R., Munker, C., 2012. Complex calc-alkaline volcanism recorded in Mesoarchean supracrustal belts north of Frederikshab Isblink, southern West Greenland: Implication for subduction zone processes in the early Earth. Precambrian Research 208-211, 90-123.

Szilas, K., Van Hinsberg, V.J., Kisters, A.F.M., Hoffmann, J.E., Windley, B.F., Kokfelt, T.F., Schersten, A., Frei, R., Rosing, M.T., Münker, C., 2013b. Remnants of arc-related Mesoarchean oceanic crust in the Tartoq Group of SW Greenland. Gondwana Research 23, 436-451.

Tagai, T., Ichikawa, J., Takeda, H., Morrison, D.A., 1988. Crystallographic investigations of calcic plagioclase from the Bad Vermilion Lake Anorthosite Complex, Ontario. In Lunar and Planetary Institute Science Conference Abstracts Vol. 19, p. 1167.

Takagi, D., Sato, H., Nakagawa, M., 2005. Experimental study of a low-alkali tholeiite at 1-5 kbar: optimal condition for the crystallization of high-An plagioclase in hydrous arc tholeiite. Contributions to Mineralogy and Petrology 149, 527-540.

Taylor Jr, H.P., Epstein, S., 1962a. Relationship between $\mathrm{O}^{18} / \mathrm{O}^{16}$ ratios in coexisting minerals of igneous and metamorphic rocks. Part 1. Application to petrologic problems. Geological Society of America Bulletin 73, 461-480. 
1025 Taylor Jr, H.P., Epstein, S., 1962b. Relationship between $\mathrm{O}^{18} / \mathrm{O}^{16}$ ratios in coexisting minerals of 1026 igneous and metamorphic rocks. Part 2. Principles and experimental results. Geological 1027 Society of America Bulletin 73, 675-694.

1028 Thurston, P.C., 2002. Autochthonous development of Superior Province greenstone belts. 1029 Precambrian Research 115, 11-36.

1030 Thurston, P.C., Osmani, I.A., Stone, D., 1991. Northwestern Superior Province: review and 1031 terrane analysis. In: Thurston, P.C., Williams, H.R., Sutcliffe, R.H., Stott, G.M. (Eds.), 1032 Geology of Ontario. Ontario Geological Survey Special Volume 4, Pt. 1, pp. 81-144.

1033 Thurston, P.C, Sage, R.P., Siragusa, G.M., 1979. Geology of the Winisk Lake Area, District of 1034 1035 1036

Trueman, D.L., 1971. Petrological, structural and magnetic studies of a layered basic intrusion, 1037 Bird River Sill, Manitoba. Master's Thesis, University of Manitoba. Winnipeg, Manitoba, 1038 1039 1040 1041 1042 1043 Valley, J.W., 1986. Stable isotope geochemistry of metamorphic rocks. In: Valley, J.W., Taylor, Canada.

Kenora, Patricia Portion. Ontario Ministry of Natural Resources, Ontario Geological Survey Report 193, 169 pp. H.P., O’Neil, J.R. (Eds.), Stable Isotopes in High Temperature Geological Processes. In: Mineralogical Society of America Reviews in Mineralogy vol. 16, pp. 445-489.

Whalen, J.B., Currie, K.L., Chappell, B.W., 1987. A-type granites geochemical characteristics, discrimination and petrogenesis. Contributions to Mineralogy and Petrology 95, 407-419.

1044 Whalen, J.B., McNicoll, V., Longstaffe, F.J., 2004. Juvenile ca. 2.735-2.720 Ga high- and 1045 low-Al tonalitic plutons: implications for TTG and VMS petrogenesis, western Superior 
Province, Canada. Precambrian Research 132, 275-301.

1047 Westerman, C.J., 1978. Tectonic evolution of a part of the English River Subprovince, northwestern Ontario. Ph.D. thesis, McMaster University. Hamilton, Ontario, Canada, 292 p.

Windley, B.F., 1973. Archean anorthosites: a review with the Fiskenæsset Complex, West Publication 3, 319-332.

Windley, B.F., 1995. The evolving continents (3rd ed.). London, Wiley, 526 p.

Wood, J., 1980. Epiclastic sedimentation and stratigraphy in the North Spirit Lake and Rainy

Wood, J., Dekker, J., Jansen, J.G., Keay, J.P., Panagapko, D., 1980. Mine Center Area, District of Rainy River. Ontario Geological Survey Preliminary Maps P2201 and P2202; Geological series, Scale, 1:15, 840

Wu, Y., Zheng, Y., 2004. Genesis of zircon and its constraints on interpretation of U-Pb 
Fig. 1. World map showing the locations of known Archean anorthosites (solid black circles) and areas known or suspected to be underlain by Archean rocks and reworked equivalents (shaded).

1070 The solid red circle is the location of the BVLA Complex. Base map modified from Condie 1071 (1982) and de Wit et al. (1988).

1072

Fig. 2. Location of the Wabigoon subprovince within the Superior Province (modified from Card and Ciesielski, 1986).

1075

Fig. 3. Geological map of the Bad Vermilion Lake region.

1077

Fig. 4. Geologic map of the BVLA Complex (modified from Ashwal et al., 1983).

Fig. 5. Field photographs illustrating primary igneous lithological characteristics and field relationships of the Bad Vermilion Lake Complex. (a) Field relationship between the gabbro and anorthosite layers. (b) Field relationship between the leucogabbro and anorthosite. (c-d) Photographs of the anorthosite and gabbro. (e-f) Granitic rocks.

Fig. 6. Photomicrographs illustrating petrographic characteristics of the Bad Vermilion Lake abundant chlorite group minerals. (e-f) Anorthosite containing plagioclase altered to epidote 
group minerals. (g-h) Anorthosite with epidote alteration and relict plagioclase.

Fig. 7. Scanning Electron Microscope (SEM) with backscattered electron (BSE) images for the anorthosite. (b-d) Primary and altered (to albite and epidote) plagioclase grains in the anorthosite; mafic matrix is altered to chlorite. (e-f) Primary and altered (to epidote) plagioclase grains in the gabbro, containing magnetite grains. (g-h) Titanium-rich minerals, such as rutile and titanite, which are abundant in Group 2 gabbro samples.

Fig. 8. Photomicrographs illustrating petrographic characteristics of granitic rocks associated with the BVLA Complex. The granitic rocks are composed of 55\% quartz, 25\% plagioclase (some altered to epidote), 5-10\% K-feldspar, 10\% biotite and 5\% accessory minerals.

Fig. 9. Cathodoluminescence (CL) images of zircons from granitic sample BVL2013-042. The red circles show LA-ICP-MS dating spots.

Fig. 10. Cathodoluminescence (CL) images of zircons from granitic sample BVL2013-043. The red circles show LA-ICP-MS dating spots.

Fig. 11. Zircon $\mathrm{U} / \mathrm{Pb}$ concordia diagram for the analyzed granitic samples, providing ages of 
1111 Fig. 12. $\mathrm{SiO}_{2}$ (wt.\%) versus $\mathrm{CaO}$ (wt.\%), $\mathrm{TiO}_{2}$ (wt.\%), $\mathrm{Al}_{2} \mathrm{O}_{3}$ (wt.\%), and $\mathrm{Fe}_{2} \mathrm{O}_{3}$ (wt.\%) for the 1112 BVLA Complex.

1114 Fig. 13. (a-e). $\mathrm{MgO}$ (wt.\%) versus $\mathrm{Al}_{2} \mathrm{O}_{3}$ (wt.\%), $\mathrm{CaO}$ (wt.\%), $\mathrm{Fe}_{2} \mathrm{O}_{3}$ (wt.\%), $\mathrm{Ni}$ (ppm) and $\mathrm{Co}$ 1115 plots for the Bad Vermilion Lake Complex, and (f) $\mathrm{Al}_{2} \mathrm{O}_{3}$ (wt.\%) versus $\mathrm{Fe}_{2} \mathrm{O}_{3}$ (wt.\%) plots for 1116 the BVLA Complex.

Fig. 14. $\mathrm{Zr}(\mathrm{ppm})$ versus $\mathrm{TiO}_{2}$ (wt.\%), $\mathrm{Nb}$ (ppm), $\mathrm{Sm}(\mathrm{ppm})$, and $\mathrm{Nd}$ (ppm) variation diagrams for the BVLA Complex, suggesting a co-magmatic origin for these rocks.

Fig. 15. (a-c). Chondrite-normalized REE patterns for the Bad Vermilion Lake anorthosite,

Primitive mantle-normalized trace element patterns for the Bad Vermilion Lake anorthosite, gabbro and leucogabbro. Normalization values are from Hofmann (1988).

Fig. 16. (a). Chondrite-normalized REE patterns for the Bad Vermilion Lake granitic rocks.

1127 Normalization values are from Sun and McDonough (1989). (b). Primitive mantle-normalized 
1131 Fig. 17. Whole-rock $\delta^{18} \mathrm{O}\left(\%\right.$ ) versus (a) $\mathrm{Ce} / \mathrm{Ce}^{*}$, (b) $\mathrm{Nb} / \mathrm{Nb}^{*}$, (c) $\mathrm{Mg} \#$ and (d) $\mathrm{Al}_{2} \mathrm{O}_{3}$ for the 1132 BVLA Complex.

Fig. 18. Comparison of the trace element geochemistry of gabbros from the BVLA Complex with gabbros from Cenozoic oceanic arc (e.g. Aleutian Arc, Mariana Arc, Scotia Arc and Tonga Arc), gabbros from the Semail Ophiolite in Oman and gabbros from South West Indian Ridge. (a)

$1137 \mathrm{Nb} / \mathrm{Nb}^{*}$ versus $\mathrm{La} / \mathrm{Sm}_{\mathrm{cn}}$. (b) $\mathrm{Th} / \mathrm{Nb}$ versus $\mathrm{La} / \mathrm{Nb}$. Both Group 1 and Group 2 gabbros from the 1138 BVLA Complex plot predominantly within the field of gabbros from Cenozoic oceanic arc 1139 setting. Data for Cenozoic arcs were obtained from GEOROC database 1140 (http://georoc.mpch-mainz.gwdg.de). Data from the Oman ophiolite are for samples from the 1141 Wadi Abyad section in the south-central part of the ophiolite following the lithological division 1142 of MacLeod and Yaouancq (2000). Data for South West Indian Ridge are from Coogan et al. 1143 (2001).

1145 Fig. 19. Schematic model illustrating the proposed geodynamic evolution of the BVLA Complex 1146 and associated granitic rocks. 


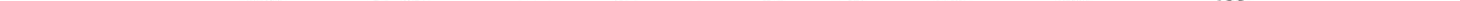





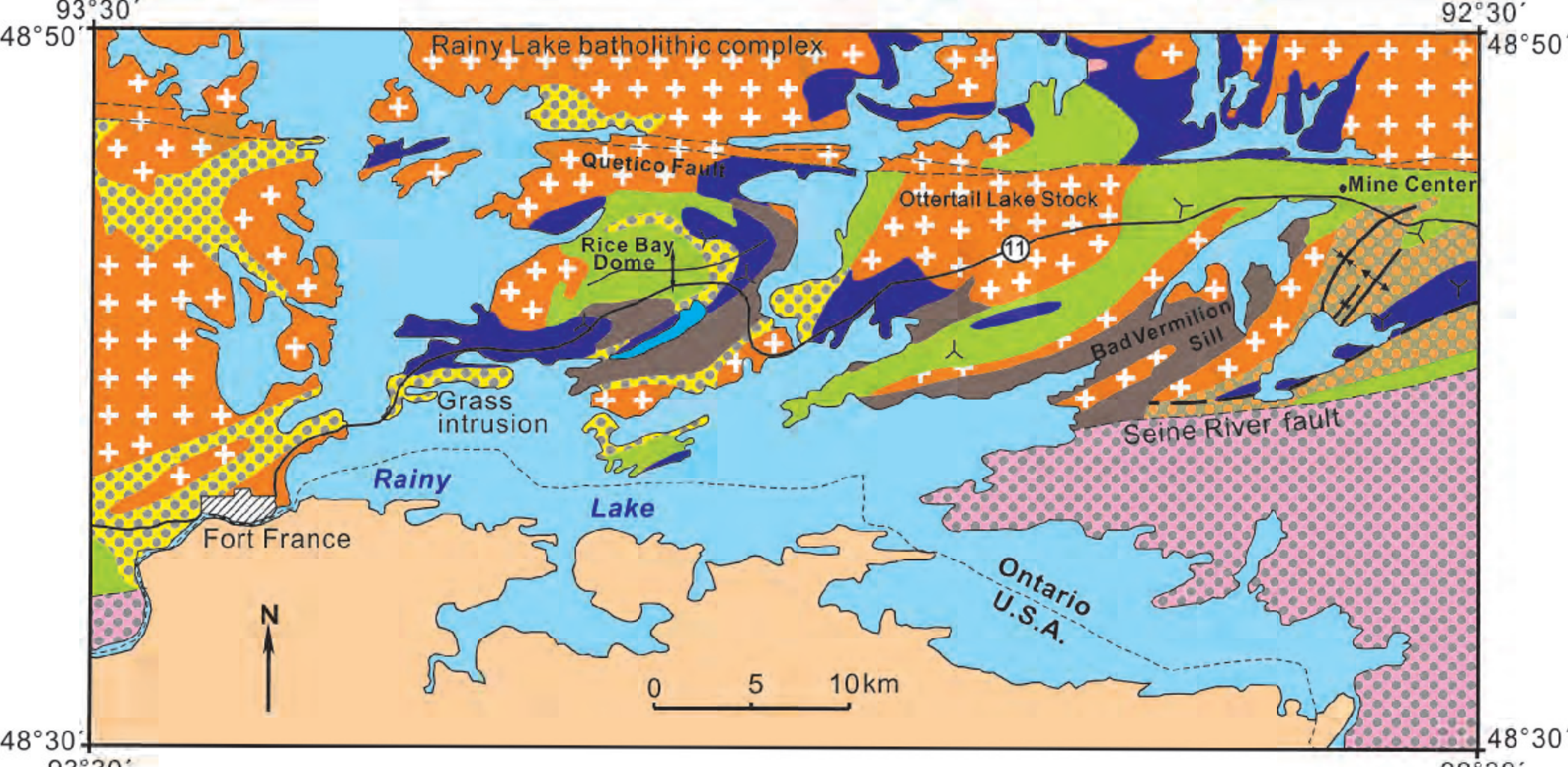

\section{Legend:}

:.:.t. Granitoid rocks

\section{Seine metasedimentary rocks}

Conglomerate, arenite

Quetico metasedimentary rocks

QH. Wacke (Quetico Subprovince)

Coutching metasedimentary rocks $\because \because$ Wacke
Keewatin

Gabbro, anorthosite

Predominantly mafic volcanic rocks

Predominantly felsic volcanic rocks

Unmapped Area

Town Area

Geological boundary
-..-- Fault

入 Younging direction

+ Syncline, anticline

$x^{\prime}$ Antiform

_- International Boundary (11) Highway 
Bad Vermilion Lake

Anothosite Complex, Ontario

\section{QUETICOFAULT}

Migmatites

Metasedimentary rocks

Granitic rocks

Gabbro

- Fe-Ti oxide masses

Anorthosite

Metavolcanics

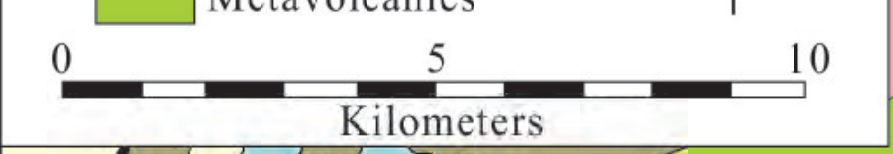

\section{0} Kilometers

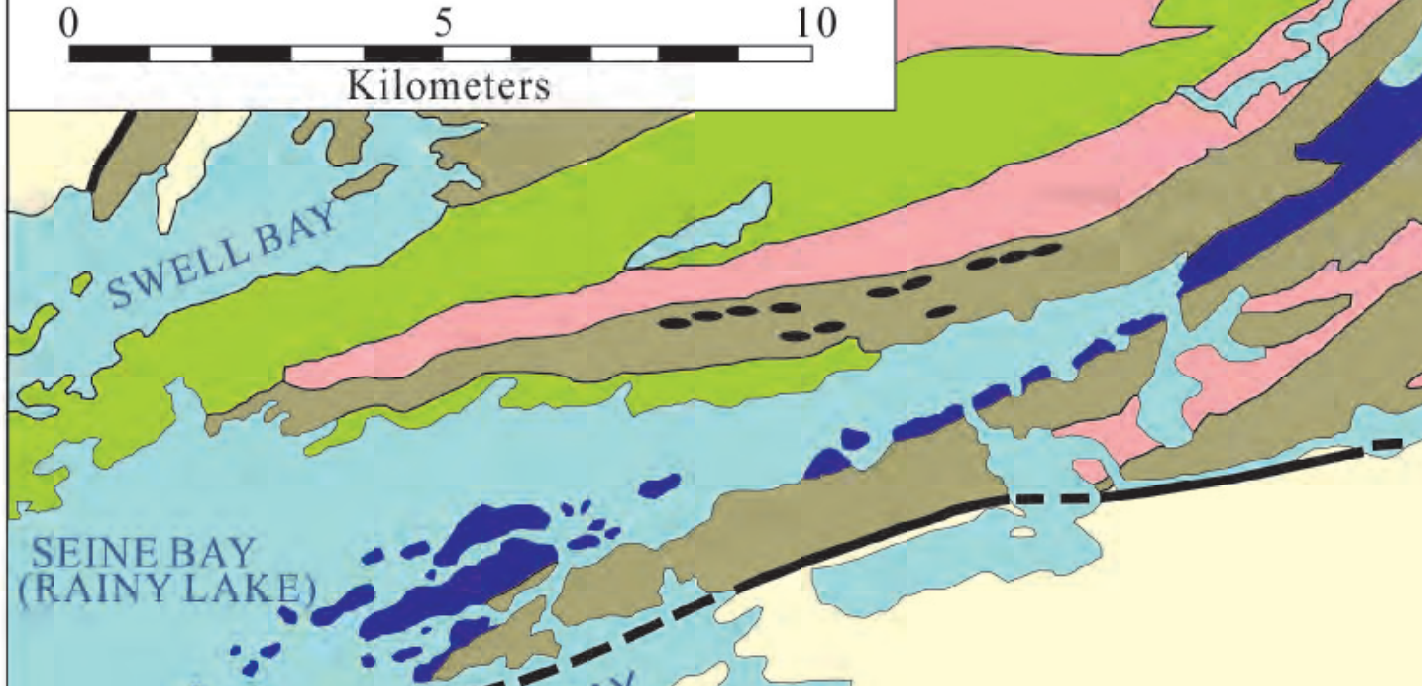

SEINEBAY

$$
\text { - }
$$

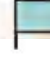




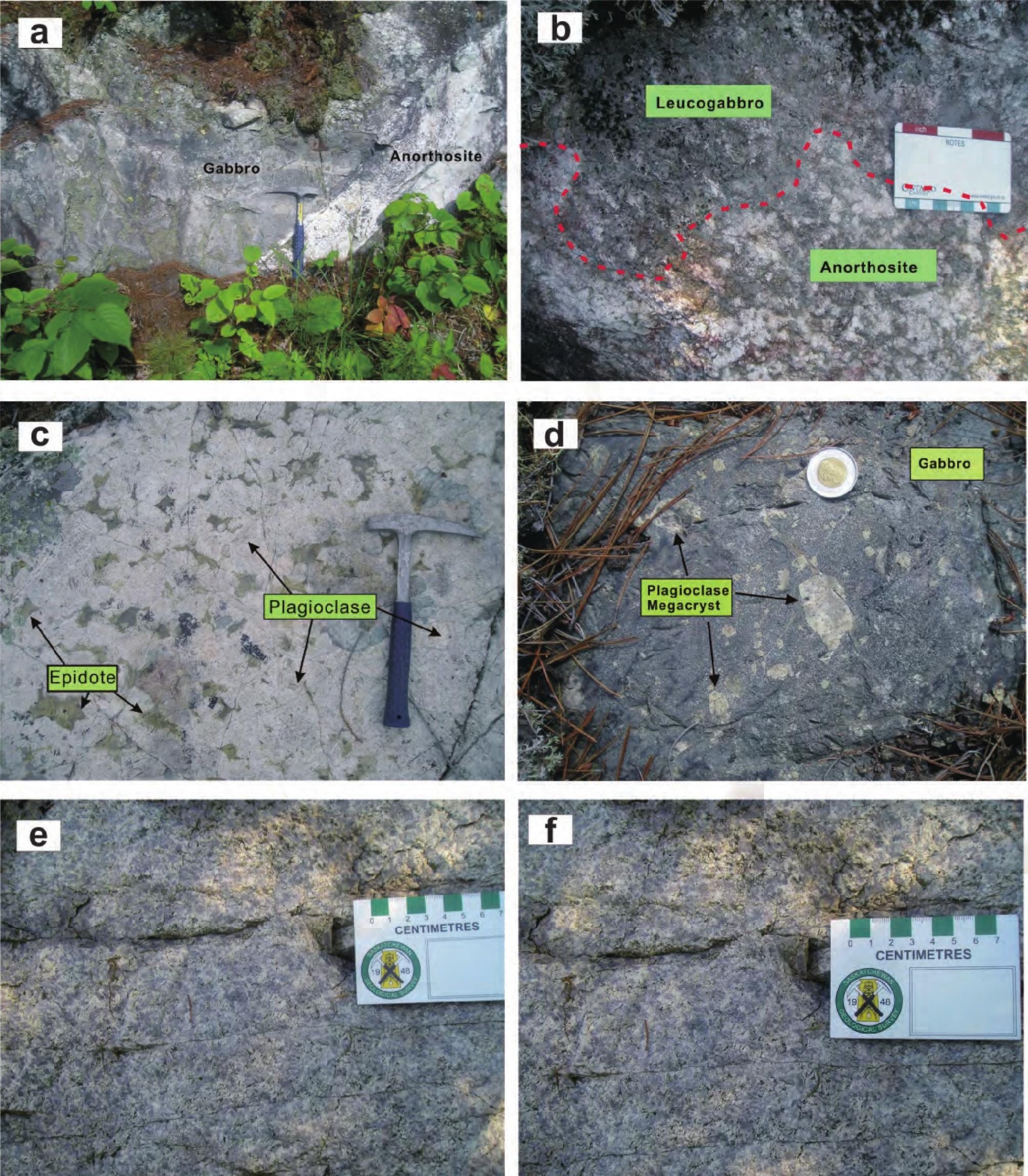



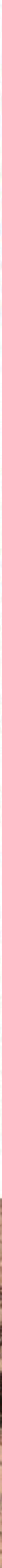


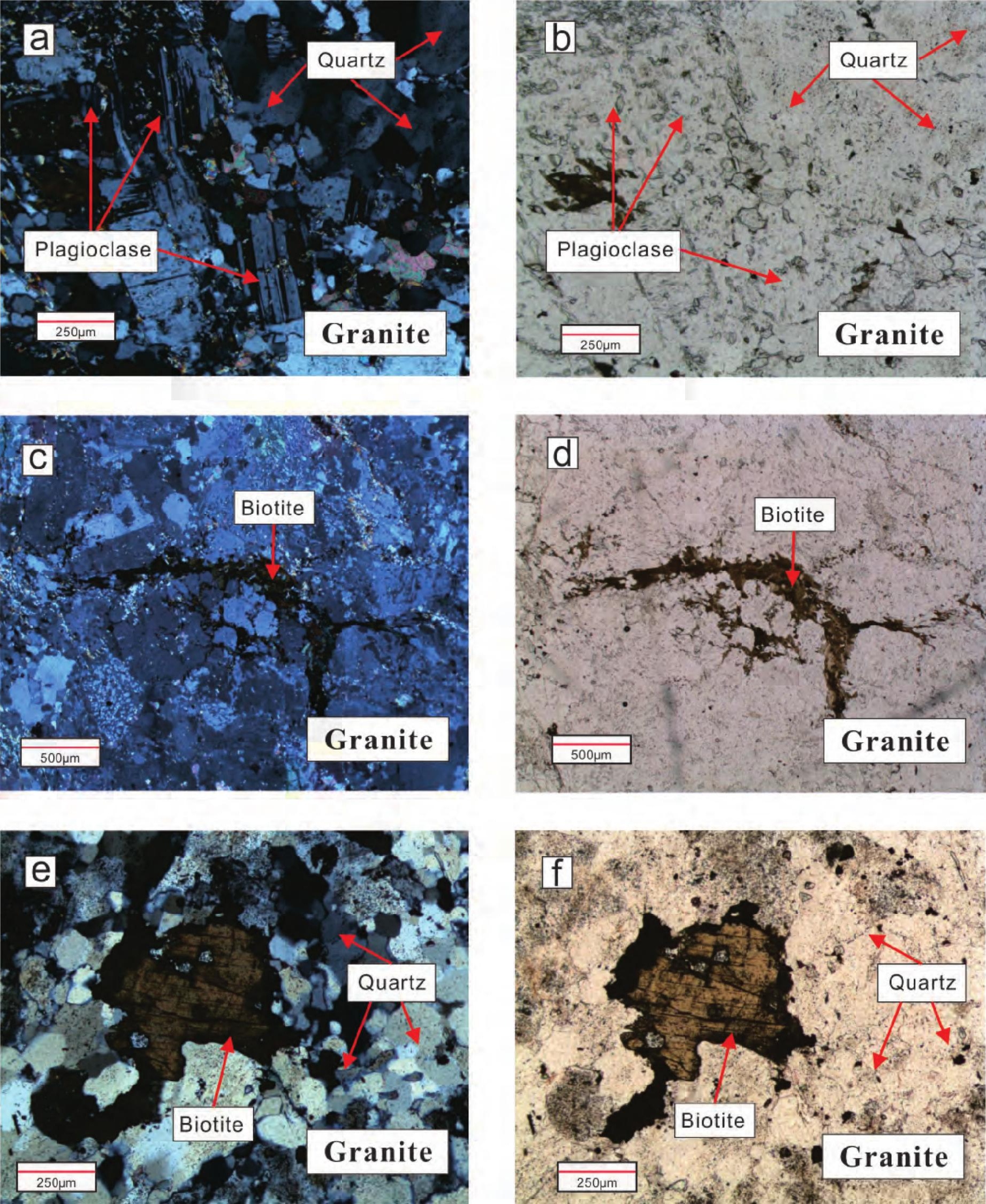




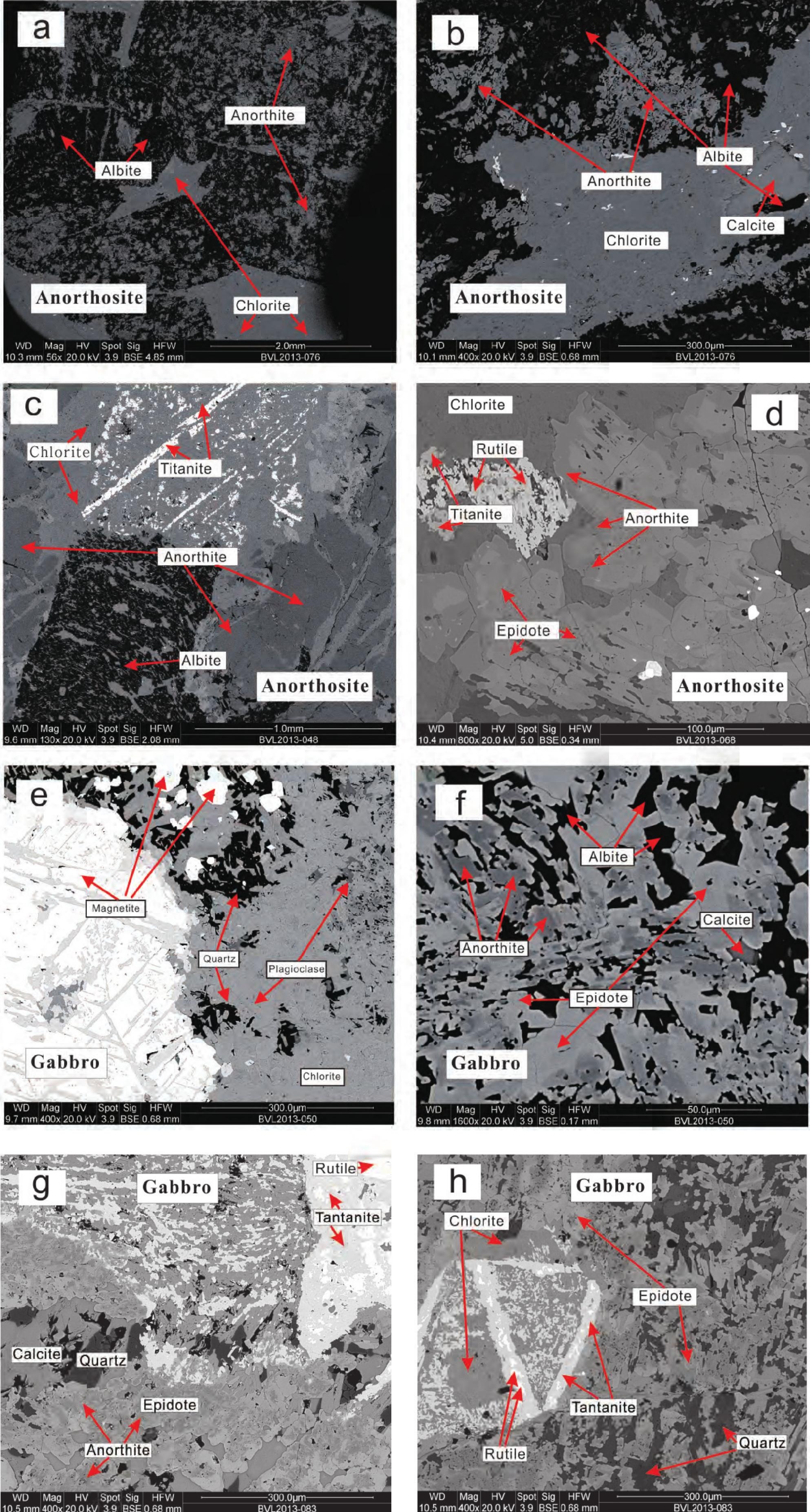



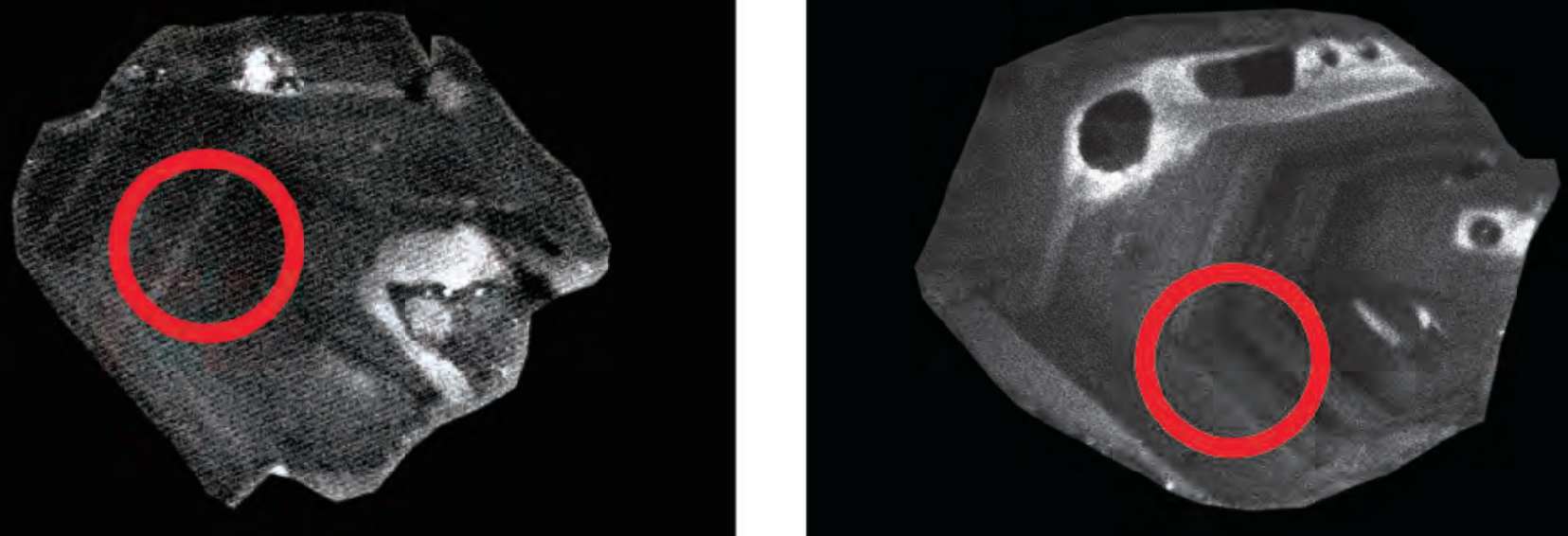

$50 \mu \mathrm{m}$

C BVL2013-42-12

d BVL2013-42-18

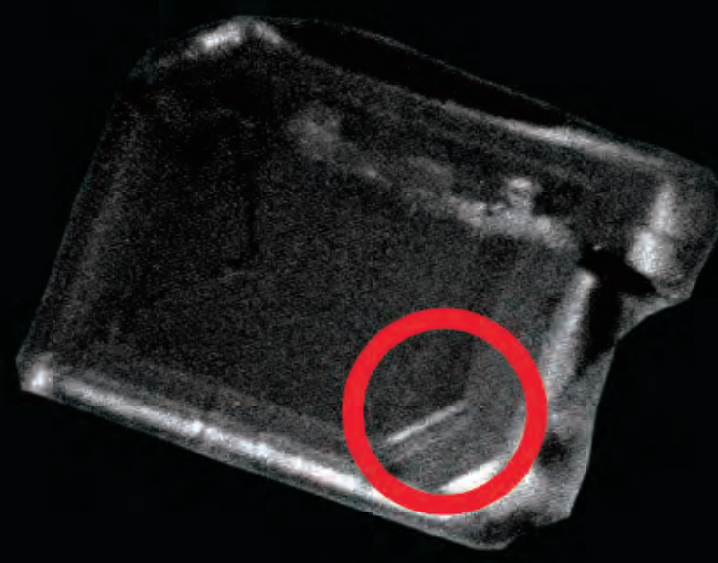

$50 \mu \mathrm{m}$

e BVL2013-42-16

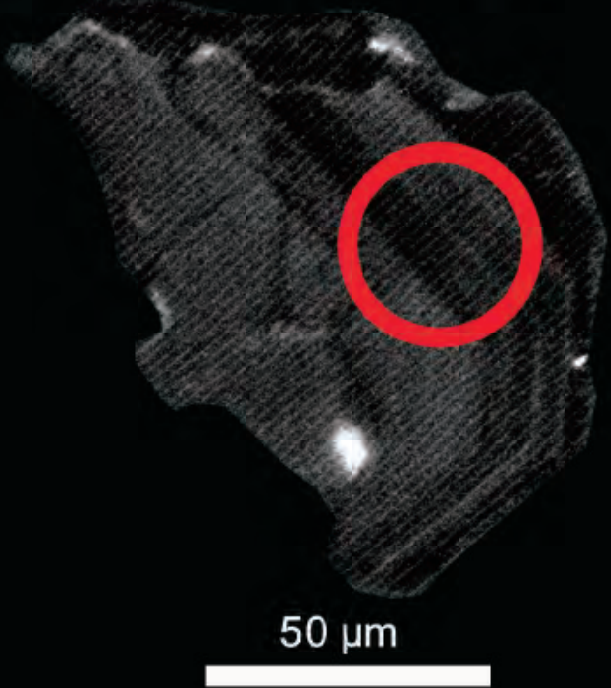

f

BVL2013-42-01

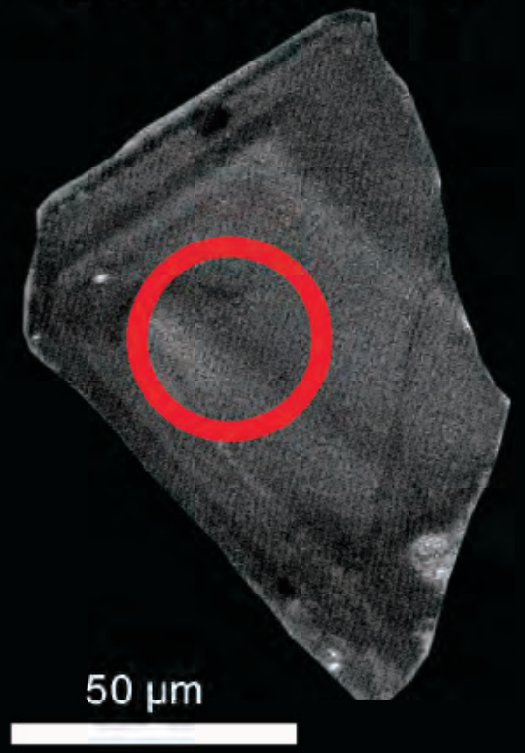


a BVL2013-043-1

b BVL2013-043-2
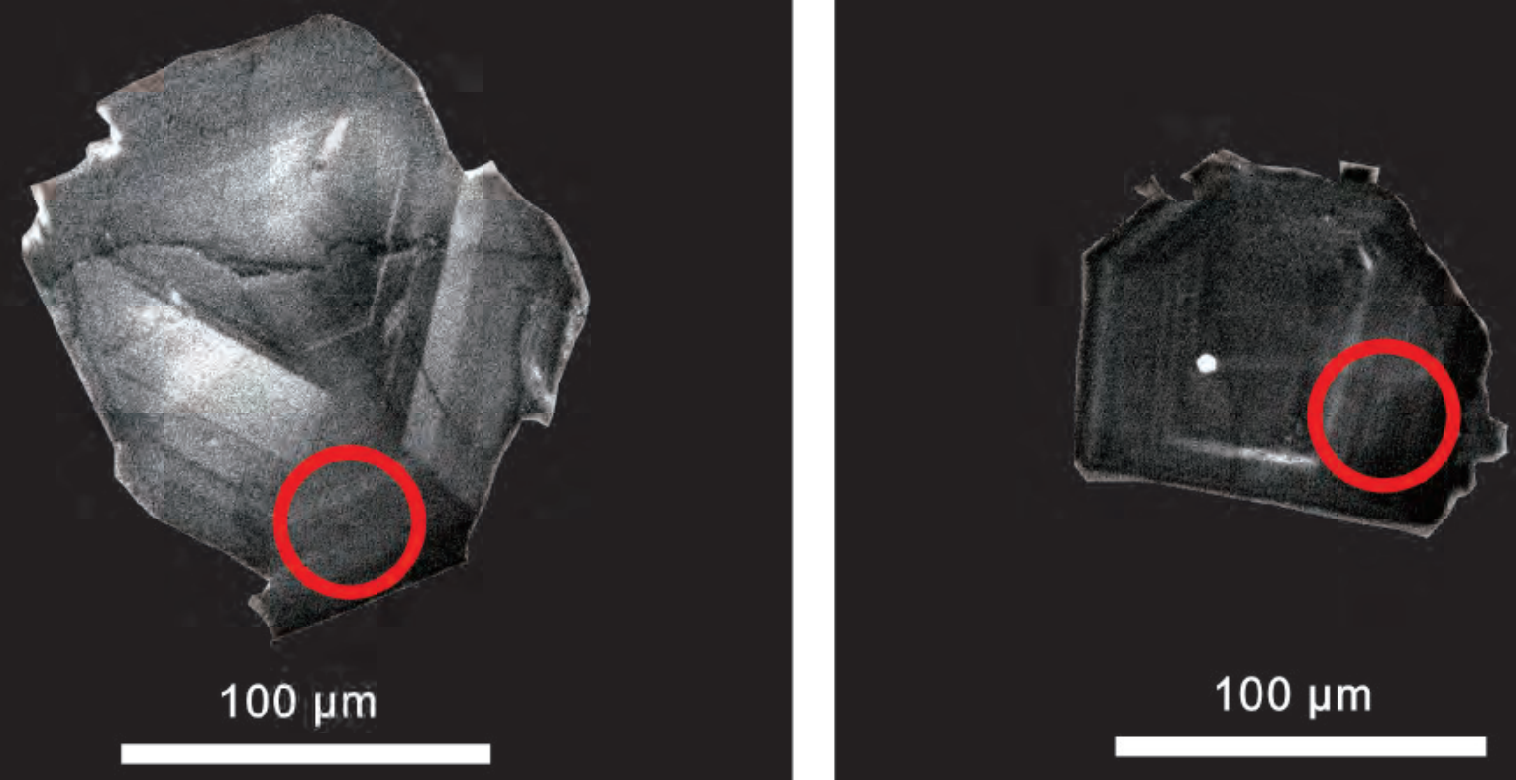

C BVL2013-043-3

d BVL2013-043-6

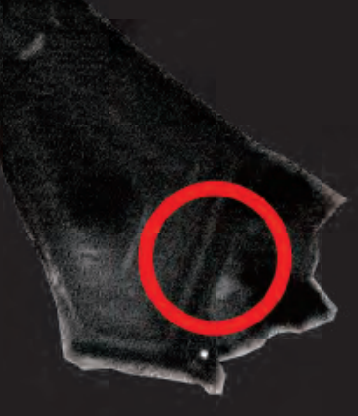

$100 \mu \mathrm{m}$

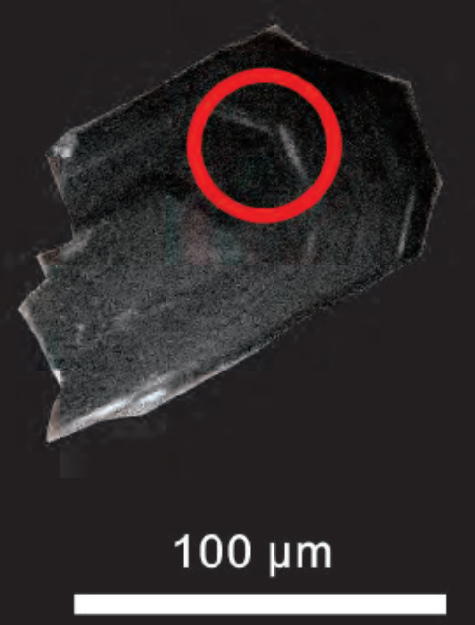

$100 \mu \mathrm{m}$

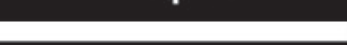

e BVL2013-043-26

f BVL2013-043-27

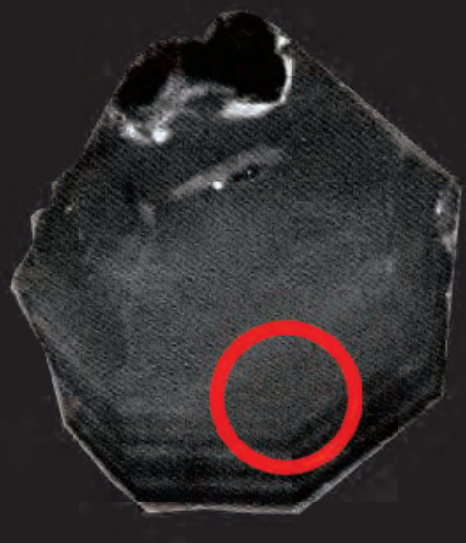

$100 \mu \mathrm{m}$ 

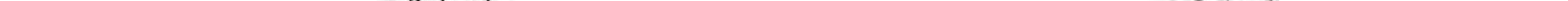


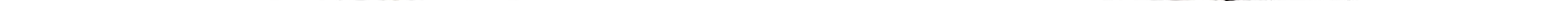



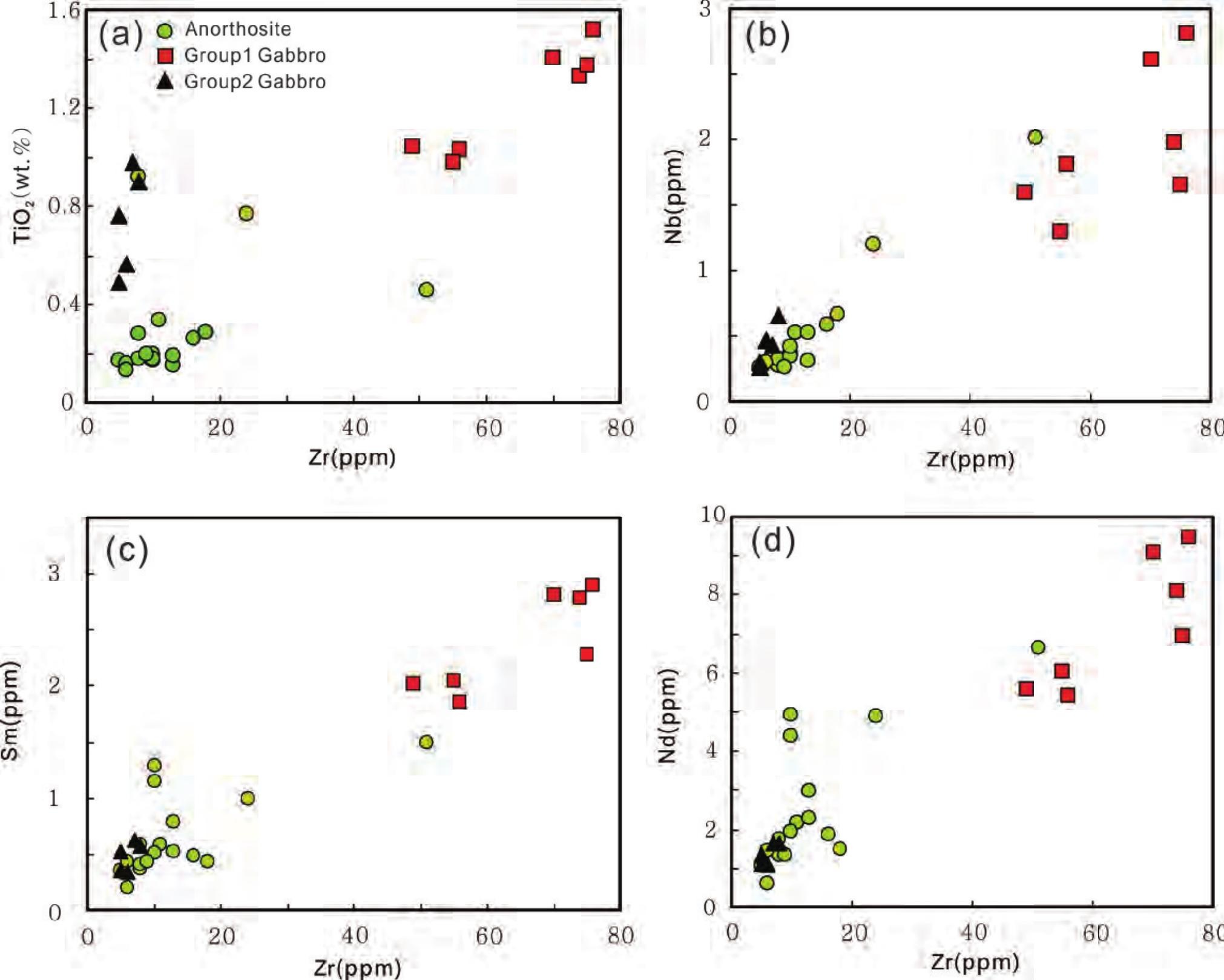

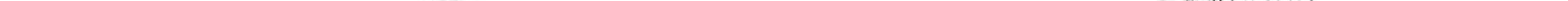

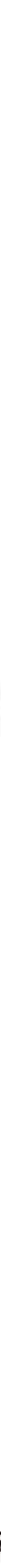
(a) $2.75-2.72 \mathrm{Ga}$

Wawa arc Quetico trench Wabigoon arc

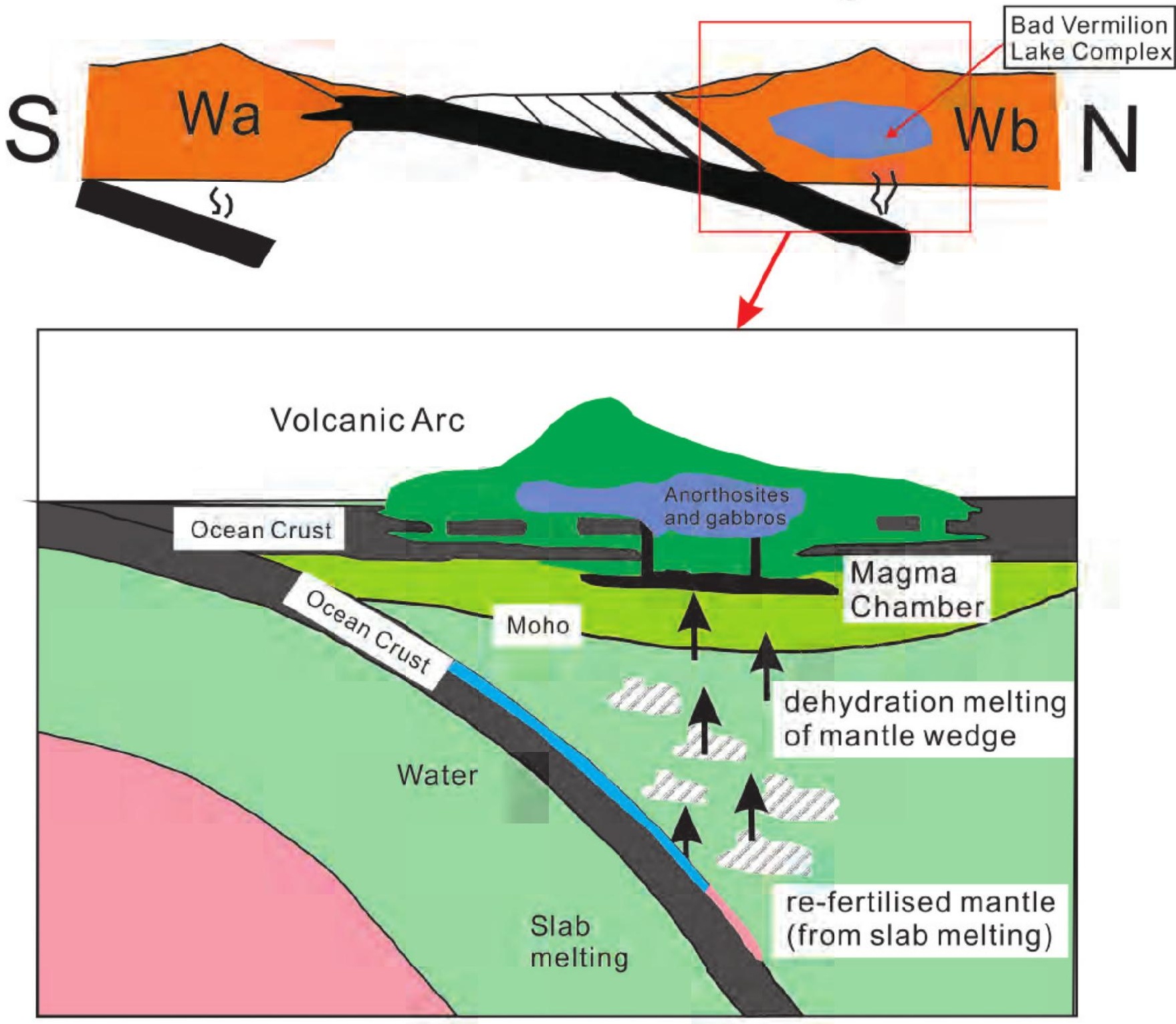

\section{(b) $2.72-2.65 \mathrm{Ga}$}

Post extensional

Continuing arc activity
Continuing accretion

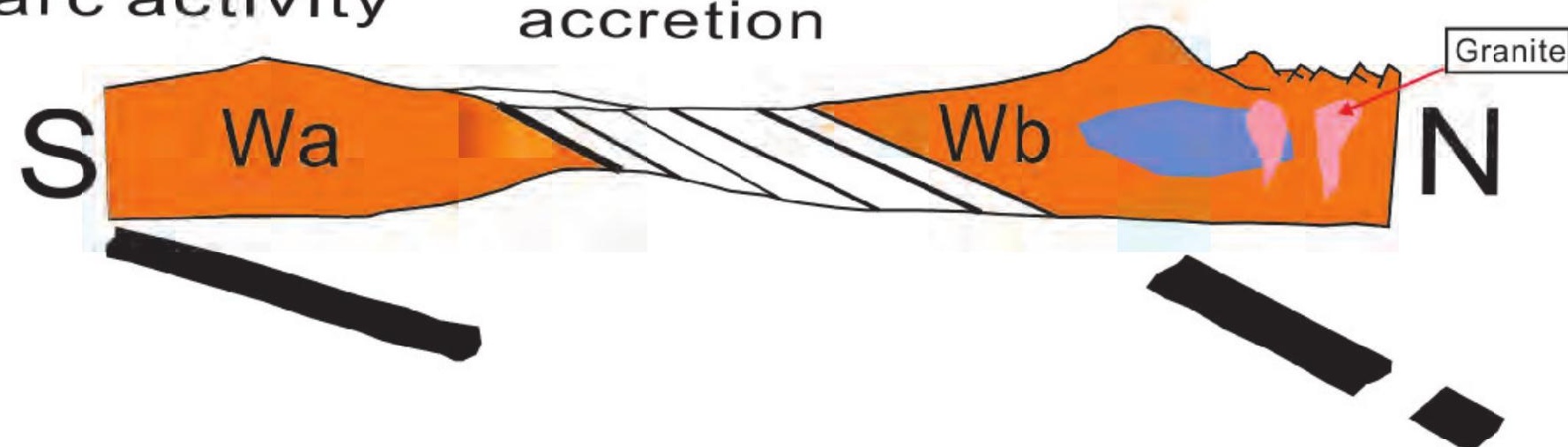


Table 1. Compilation of Archean anorthosite complexes in the Superior Province.

\begin{tabular}{lllll}
\hline Name of the complex & Province & Metamorphic grade & Degree of deformation & References \\
\hline Bird River & Manitoba & Medium & Medium & Trueman et al. (1971) \\
$\begin{array}{l}\text { Pipestone Lake } \\
\text { Bad Vermilion Lake }\end{array}$ & Ontario & Low & Medium & Corkery et al. (1992) \\
Shawmere & Ontario & High & Low to medium & Ashwal et al. (1983, 1985) \\
Doré Lake & Quebec & Low to medium & Low to medium & Mortensen (1993) \\
Big Trout Lake & Ontario & Medium & Medium & Thurston et al. (1980) \\
Bell River & Bell River & Low to medium & Low to medium & Ashwal et al. (1993) \\
Nelson River & Manitoba & Low to high & Low to high & Hubregtse (1980)
\end{tabular}


Table 2. Results of LA-ICP-MS zircon U-Pb isotope analyses.

\begin{tabular}{|c|c|c|c|c|c|c|c|c|c|c|c|c|c|c|c|}
\hline Spots & $\mathrm{Pb}(\mathrm{ppm})$ & Th (ppm) & 1) $\mathrm{U}(\mathrm{ppm})$ & $\mathrm{Th} / \mathrm{U}$ & ${ }^{207} \mathrm{~Pb} /{ }^{235} \mathrm{U}$ & $\pm 1 \sigma$ & ${ }^{206} \mathrm{~Pb} /{ }^{238} \mathrm{U}$ & $\pm 1 \sigma$ & rho & ${ }^{207} \mathrm{~Pb} /{ }^{206} \mathrm{~Pb}$ age $(\mathrm{Ma})$ & $\pm 1 \sigma$ & ${ }^{207} \mathrm{~Pb} /{ }^{235} \mathrm{U}$ age $(\mathrm{Ma})$ & $\pm 1 \sigma$ & ${ }^{206} \mathrm{~Pb} /{ }^{238} \mathrm{U}$ & $\pm 1 \sigma$ \\
\hline \multicolumn{16}{|c|}{$\begin{array}{l}\text { Sample BVL2013-042 N } 515070 \text { E } 5393874 \\
\end{array}$} \\
\hline BVL-042-1 & 377 & 145 & 210 & 0.69 & 13.8062 & 0.3189 & 0.5680 & 0.0050 & 0.381 & 2598 & 38.9 & 2737 & 21.9 & 2899 & 20.6 \\
\hline BVL-042-2 & 861 & 354 & 414 & 0.85 & 13.3359 & 0.3308 & 0.5463 & 0.0063 & 0.467 & 2602 & 38.3 & 2704 & 23.5 & 2810 & 26.4 \\
\hline BVL-042-3 & 202 & 94.8 & 131 & 0.72 & 12.2352 & 0.2923 & 0.5072 & 0.0049 & 0.401 & 2587 & 39.5 & 2623 & 22.5 & 2645 & 20.8 \\
\hline BVL-042-4 & 488 & 209 & 264 & 0.79 & 13.4026 & 0.3303 & 0.5379 & 0.0058 & 0.441 & 2646 & 40.9 & 2708 & 23.4 & 2774 & 24.6 \\
\hline BVL-042-5 & 152 & 65.0 & 101 & 0.65 & 13.0296 & 0.3659 & 0.5317 & 0.0065 & 0.435 & 2617 & 46.3 & 2682 & 26.5 & 2749 & 27.4 \\
\hline BVL-042-6 & 408 & 179 & 251 & 0.71 & 12.9952 & 0.3893 & 0.5116 & 0.0060 & 0.392 & 2676 & 49.4 & 2679 & 28.3 & 2663 & 25.6 \\
\hline BVL-042-7 & 377 & 157 & 222 & 0.71 & 13.6391 & 0.3924 & 0.5257 & 0.0062 & 0.413 & 2713 & 47.8 & 2725 & 27.3 & 2723 & 26.4 \\
\hline BVL-042-8 & 140 & 62.3 & 98.8 & 0.63 & 12.4680 & 0.3363 & 0.5055 & 0.0059 & 0.432 & 2626 & 75.0 & 2640 & 25.4 & 2637 & 25.3 \\
\hline BVL-042-9 & 701 & 344 & 390 & 0.88 & 12.8374 & 0.3066 & 0.5080 & 0.0050 & 0.411 & 2733 & 38.1 & 2668 & 22.6 & 2648 & 21.4 \\
\hline BVL-042-10 & 135 & 58.4 & 96.2 & 0.61 & 13.2886 & 0.3520 & 0.5302 & 0.0054 & 0.384 & 2655 & 41.4 & 2700 & 25.1 & 2742 & 22.8 \\
\hline BVL-042-11 & 367 & 151 & 218 & 0.69 & 13.2953 & 0.3729 & 0.5393 & 0.0056 & 0.372 & 2631 & 44.4 & 2701 & 26.6 & 2781 & 23.6 \\
\hline BVL-042-12 & 302 & 174 & 174 & 1.00 & 13.0945 & 0.4219 & 0.5287 & 0.0070 & 0.409 & 2643 & 49.7 & 2686 & 30.4 & 2736 & 29.5 \\
\hline BVL-042-13 & 163 & 69.6 & 110 & 0.63 & 13.4284 & 0.4310 & 0.5427 & 0.0066 & 0.381 & 2637 & 50.5 & 2710 & 30.4 & 2795 & 27.8 \\
\hline BVL-042-14 & 349 & 152 & 223 & 0.68 & 13.0484 & 0.4132 & 0.5352 & 0.0066 & 0.391 & 2614 & 51.1 & 2683 & 29.9 & 2764 & 27.9 \\
\hline BVL-042-15 & 482 & 190 & 251 & 0.76 & 13.7281 & 0.4073 & 0.5609 & 0.0063 & 0.380 & 2620 & 81.9 & 2731 & 28.1 & 2870 & 26.1 \\
\hline BVL-042-16 & 384 & 177 & 218 & 0.81 & 12.7447 & 0.4047 & 0.5173 & 0.0062 & 0.380 & 2631 & 53.2 & 2661 & 30.0 & 2688 & 26.6 \\
\hline BVL-042-17 & 226 & 101 & 139 & 0.73 & 12.5554 & 0.4208 & 0.5197 & 0.0054 & 0.310 & 2591 & 57.7 & 2647 & 31.6 & 2698 & 23.0 \\
\hline BVL-042-18 & 219 & 90 & 123 & 0.74 & 13.4885 & 0.5305 & 0.5545 & 0.0075 & 0.342 & 2606 & 68.5 & 2714 & 37.2 & 2844 & 30.9 \\
\hline BVL-042-19 & 117 & 52.5 & 86.6 & 0.61 & 12.1301 & 0.5664 & 0.5052 & 0.0082 & 0.347 & 2587 & 81.2 & 2615 & 43.8 & 2636 & 35.1 \\
\hline BVL-042-20 & 435 & 205 & 257 & 0.80 & 11.9157 & 0.4764 & 0.4952 & 0.0069 & 0.348 & 2581 & 68.8 & 2598 & 37.5 & 2593 & 29.7 \\
\hline BVL-042-21 & 64.4 & 27.7 & 59.1 & 0.47 & 11.6752 & 0.5492 & 0.4881 & 0.0099 & 0.433 & 2606 & 83.3 & 2579 & 44.0 & 2563 & 43.1 \\
\hline BVL-042-22 & 168 & 74.8 & 110 & 0.68 & 13.0848 & 0.4545 & 0.5390 & 0.0077 & 0.411 & 2611 & 59.6 & 2686 & 32.8 & 2779 & 32.3 \\
\hline BVL-042-23 & 418 & 176 & 252 & 0.70 & 14.0296 & 0.4068 & 0.5621 & 0.0057 & 0.348 & 2643 & 49.7 & 2752 & 27.5 & 2875 & 23.4 \\
\hline BVL-042-24 & 188 & 77.5 & 112 & 0.69 & 13.9299 & 0.4021 & 0.5628 & 0.0065 & 0.401 & 2632 & 48.9 & 2745 & 27.4 & 2878 & 26.9 \\
\hline BVL-042-25 & 501 & 220 & 281 & 0.78 & 14.3545 & 0.3495 & 0.5781 & 0.0055 & 0.392 & 2639 & 38.4 & 2773 & 23.2 & 2941 & 22.6 \\
\hline BVL-042-26 & 133 & 54 & 97 & 0.56 & 13.4542 & 0.2665 & 0.5214 & 0.0043 & 0.416 & 2709 & 32.3 & 2712 & 18.8 & 2705 & 18.3 \\
\hline BVL-042-27 & 143 & 57 & 102 & 0.56 & 13.7381 & 0.2699 & 0.5315 & 0.0050 & 0.480 & 2714 & 32.4 & 2732 & 18.7 & 2748 & 21.1 \\
\hline BVL-042-28 & 145 & 58 & 103 & 0.56 & 13.7136 & 0.2953 & 0.5373 & 0.0048 & 0.414 & 2700 & 38.7 & 2730 & 20.5 & 2772 & 20.1 \\
\hline \multicolumn{16}{|c|}{$\begin{array}{lll}\text { Sample BVL2013-043 } & \text { N 515030 E } 5393907 \\
\end{array}$} \\
\hline$\overline{\text { BVL-043-1 }}$ & 250 & 82 & 115 & 0.71 & 14.2339 & 0.3840 & 0.5372 & 0.0064 & 0.4434 & 2746 & 40.9 & 2765 & 25.7 & 2772 & 27.0 \\
\hline BVL-043-2 & 919 & 270 & 300 & 0.90 & 14.3993 & 0.4102 & 0.5505 & 0.0075 & 0.4784 & 2725 & 44.1 & 2776 & 27.1 & 2827 & 31.2 \\
\hline BVL-043-3 & 739 & 222 & 291 & 0.76 & 14.3648 & 0.3917 & 0.5510 & 0.0056 & 0.3748 & 2718 & 44.1 & 2774 & 26.0 & 2829 & 23.5 \\
\hline BVL-043-4 & 462 & 135 & 217 & 0.62 & 13.5215 & 0.4305 & 0.5269 & 0.0065 & 0.3877 & 2690 & 50.6 & 2717 & 30.2 & 2728 & 27.5 \\
\hline BVL-043-5 & 463 & 137 & 204 & 0.68 & 13.2846 & 0.4396 & 0.5253 & 0.0072 & 0.4118 & 2668 & 52.8 & 2700 & 31.3 & 2722 & 30.3 \\
\hline BVL-043-6 & 871 & 279 & 305 & 0.92 & 13.1754 & 0.4790 & 0.5200 & 0.0066 & 0.3497 & 2669 & 58.6 & 2692 & 34.4 & 2699 & 28.1 \\
\hline BVL-043-7 & 467 & 144 & 201 & 0.71 & 13.1314 & 0.4991 & 0.5200 & 0.0070 & 0.3557 & 2666 & 62.0 & 2689 & 35.9 & 2699 & 29.8 \\
\hline BVL-043-8 & 272 & 80 & 149 & 0.54 & 12.7262 & 0.4506 & 0.5164 & 0.0073 & 0.3966 & 2626 & 57.4 & 2660 & 33.4 & 2684 & 30.9 \\
\hline BVL-043-9 & 456 & 139 & 200 & 0.70 & 13.2897 & 0.4406 & 0.5293 & 0.0066 & 0.3746 & 2660 & 55.6 & 2700 & 31.4 & 2739 & 27.8 \\
\hline BVL-043-10 & 420 & 133 & 205 & 0.65 & 13.0482 & 0.4122 & 0.5225 & 0.0064 & 0.3894 & 2647 & 51.7 & 2683 & 29.8 & 2710 & 27.3 \\
\hline BVL-043-11 & 996 & 314 & 367 & 0.86 & 13.3231 & 0.4342 & 0.5255 & 0.0069 & 0.4046 & 2670 & 53.9 & 2703 & 30.8 & 2722 & 29.3 \\
\hline BVL-043-12 & 342 & 101 & 163 & 0.62 & 13.7824 & 0.5282 & 0.5415 & 0.0073 & 0.3537 & 2680 & 64.5 & 2735 & 36.3 & 2790 & 30.7 \\
\hline BVL-043-13 & 244 & 81 & 119 & 0.68 & 13.5523 & 0.4423 & 0.5296 & 0.0069 & 0.3985 & 2688 & 52.3 & 2719 & 30.9 & 2740 & 29.1 \\
\hline
\end{tabular}


Table 2. Continued.

\begin{tabular}{|c|c|c|c|c|c|c|c|c|c|c|c|c|c|c|c|}
\hline Spots & $\mathrm{Pb}(\mathrm{ppm})$ & Th (ppm) & $\mathrm{U}(\mathrm{ppm})$ & $\mathrm{Th} / \mathrm{U}$ & ${ }^{207} \mathrm{~Pb} /{ }^{235} \mathrm{U}$ & $\pm 1 \sigma$ & ${ }^{206} \mathrm{~Pb} /{ }^{238} \mathrm{U}$ & $\pm 1 \sigma$ & rho & ${ }^{207} \mathrm{~Pb} /{ }^{206} \mathrm{~Pb}$ age $(\mathrm{Ma})$ & $\pm 1 \sigma$ & ${ }^{207} \mathrm{~Pb} /{ }^{235} \mathrm{U}$ age $(\mathrm{Ma})$ & $\pm 1 \sigma$ & ${ }^{206} \mathrm{~Pb} /{ }^{238} \mathrm{U}$ & $\pm 1 \sigma$ \\
\hline BVL-043-14 & 628 & 200 & 265 & 0.75 & 13.8868 & 0.4133 & 0.5309 & 0.0071 & 0.4470 & 2728 & 48.1 & 2742 & 28.3 & 2745 & 29.8 \\
\hline BVL-043-15 & 164 & 44.4 & 79.3 & 0.56 & 14.5786 & 0.4410 & 0.5432 & 0.0082 & 0.4971 & 2777 & 50.5 & 2788 & 28.8 & 2797 & 34.2 \\
\hline BVL-043-16 & 551 & 174 & 236 & 0.74 & 13.5276 & 0.3702 & 0.5304 & 0.0068 & 0.4659 & 2700 & 44.4 & 2717 & 25.9 & 2743 & 28.5 \\
\hline BVL-043-17 & 928 & 294 & 352 & 0.83 & 14.0101 & 0.3519 & 0.5441 & 0.0051 & 0.3767 & 2702 & 40.7 & 2750 & 23.9 & 2800 & 21.5 \\
\hline BVL-043-18 & 853 & 269 & 345 & 0.78 & 14.0506 & 0.4150 & 0.5492 & 0.0063 & 0.3911 & 2690 & 46.9 & 2753 & 28.1 & 2822 & 26.4 \\
\hline BVL-043-19 & 405 & 112 & 171 & 0.65 & 14.6195 & 0.4457 & 0.5549 & 0.0072 & 0.4262 & 2739 & 42.4 & 2791 & 29.0 & 2846 & 29.9 \\
\hline BVL-043-20 & 829 & 269 & 331 & 0.81 & 13.8184 & 0.3870 & 0.5332 & 0.0059 & 0.3925 & 2706 & 44.4 & 2737 & 26.6 & 2755 & 24.7 \\
\hline BVL-043-21 & 634 & 194 & 237 & 0.82 & 14.5680 & 0.4236 & 0.5424 & 0.0066 & 0.4187 & 2769 & 47.8 & 2787 & 27.7 & 2794 & 27.6 \\
\hline BVL-043-22 & 823 & 259 & 282 & 0.92 & 14.3937 & 0.4717 & 0.5448 & 0.0061 & 0.3425 & 2733 & 53.1 & 2776 & 31.2 & 2804 & 25.6 \\
\hline BVL-043-23 & 736 & 234 & 274 & 0.86 & 14.7188 & 0.5357 & 0.5581 & 0.0065 & 0.3179 & 2732 & 60.8 & 2797 & 34.7 & 2859 & 26.8 \\
\hline BVL-043-24 & 222 & 62.7 & 103 & 0.61 & 14.3688 & 0.6422 & 0.5444 & 0.0083 & 0.3395 & 2732 & 74.1 & 2774 & 42.5 & 2802 & 34.5 \\
\hline BVL-043-25 & 586 & 174 & 236 & 0.74 & 14.6769 & 0.6159 & 0.5535 & 0.0069 & 0.2981 & 2743 & 70.7 & 2795 & 39.9 & 2840 & 28.8 \\
\hline BVL-043-26 & 529 & 157 & 208 & 0.76 & 14.9248 & 0.5797 & 0.5588 & 0.0072 & 0.3311 & 2750 & 63.6 & 2810 & 37.0 & 2862 & 29.8 \\
\hline BVL-043-27 & 483 & 135 & 208 & 0.65 & 14.9272 & 0.5547 & 0.5549 & 0.0072 & 0.3472 & 2761 & 60.5 & 2811 & 35.4 & 2846 & 29.7 \\
\hline BVL-043-28 & 166 & 47.3 & 71.9 & 0.66 & 15.4103 & 0.5330 & 0.5627 & 0.0072 & 0.3681 & 2796 & 56.5 & 2841 & 33.0 & 2878 & 29.6 \\
\hline BVL-043-29 & 247 & 66.0 & 113 & 0.58 & 14.6247 & 0.7375 & 0.5433 & 0.0078 & 0.2849 & 2756 & 75.8 & 2791 & 48.0 & 2797 & 32.6 \\
\hline BVL-043-30 & 132 & 36.9 & 68.7 & 0.54 & 14.5026 & 0.4931 & 0.5425 & 0.0087 & 0.4719 & 2766 & 55.9 & 2783 & 32.4 & 2794 & 36.4 \\
\hline BVL-043-31 & 203 & 58.6 & 94.3 & 0.62 & 14.7632 & 0.4415 & 0.5608 & 0.0069 & 0.4132 & 2739 & 50.2 & 2800 & 28.5 & 2870 & 28.7 \\
\hline BVL-043-32 & 557 & 174 & 236 & 0.74 & 14.1794 & 0.3927 & 0.5370 & 0.0059 & 0.3947 & 2740 & 45.4 & 2762 & 26.3 & 2771 & 24.7 \\
\hline
\end{tabular}


Table 3. Major (wt.\%) and trace (ppm) element concentrations and significant element ratios for the BVLA Complex anorthosites and leucoga

\begin{tabular}{|c|c|c|c|c|c|c|c|c|}
\hline Sample\# & BVL2013-047 (a) & BVL2013-048 & BVL2013-049 & BVL2013-053 & BVL2013-054 & BVL2013-055 & BVL2013-064 & BVL2013-066(a) \\
\hline $\mathrm{SiO}_{2}$ & 43.0 & 44.2 & 43.8 & 46.7 & 46.5 & 46.7 & 46.0 & 44.3 \\
\hline $\mathrm{TiO}_{2}$ & 0.34 & 0.28 & 0.92 & 0.18 & 0.15 & 0.17 & 0.20 & 0.21 \\
\hline $\mathrm{Al}_{2} \mathrm{O}_{3}$ & 20.8 & 23.7 & 25.8 & 26.8 & 28.2 & 27.5 & 26.1 & 26.5 \\
\hline $\mathrm{Fe}_{2} \mathrm{O}_{3}(\mathrm{~T})$ & 6.6 & 9.0 & 8.1 & 3.7 & 2.6 & 3.3 & 5.2 & 6.8 \\
\hline $\mathrm{MnO}$ & 0.103 & 0.093 & 0.076 & 0.048 & 0.041 & 0.053 & 0.078 & 0.072 \\
\hline $\mathrm{MgO}$ & 4.0 & 5.6 & 3.3 & 2.5 & 1.1 & 1.6 & 3.9 & 6.0 \\
\hline $\mathrm{CaO}$ & 13.5 & 10.0 & 9.2 & 12.8 & 15.8 & 14.7 & 12.4 & 8.8 \\
\hline $\mathrm{K}_{2} \mathrm{O}$ & 0.06 & 0.03 & 1.2 & 0.24 & 0.33 & 0.14 & 0.21 & 1.12 \\
\hline $\mathrm{Na}_{2} \mathrm{O}$ & 2.77 & 1.12 & 3.01 & 2.61 & 2.02 & 2.51 & 3.05 & 2.5 \\
\hline $\mathrm{P}_{2} \mathrm{O}_{5}$ & 0.03 & 0.03 & 0.02 & 0.02 & 0.01 & 0.03 & $<0.01$ & $<0.01$ \\
\hline LOI & 7.4 & 4.6 & 3.3 & 3.6 & 3.0 & 3.3 & 3.3 & 4.6 \\
\hline
\end{tabular}

$\begin{array}{llcl} & 7.4 & 4.6 & 3.3 \\ & 54.6 & 55.3 & 44.5\end{array}$

\begin{tabular}{|c|c|c|c|c|c|c|c|c|}
\hline $\mathrm{Cr}$ & 61 & 115 & 92 & 222 & 18 & 33 & 271 & 33 \\
\hline Co & 22 & 48 & 30 & 14 & 10 & 11 & 13 & 23 \\
\hline $\mathrm{Ni}$ & 78 & 154 & 76 & 36 & 24 & 33 & 80 & 116 \\
\hline $\mathrm{Rb}$ & 1.02 & 0.76 & 31.13 & 7.74 & 9.71 & 4.30 & 5.09 & 0.69 \\
\hline $\mathrm{Sr}$ & 144 & 113 & 206 & 141 & 197 & 171 & 124 & 87 \\
\hline $\mathrm{Ba}$ & 25 & 18 & 287 & 55 & 63 & 34 & 29 & 71 \\
\hline $\mathrm{Sc}$ & 17 & 7 & 31 & 20 & 5 & 8 & 17 & 29 \\
\hline V & 116 & 69 & 331 & 85 & 42 & 52 & 80 & 95 \\
\hline $\mathrm{Ta}$ & 0.04 & 0.02 & 0.02 & 0.02 & 0.04 & 0.02 & 0.02 & 0.22 \\
\hline $\mathrm{Nb}$ & 0.52 & 0.28 & 0.32 & 0.32 & 0.52 & 0.37 & 0.35 & 3.31 \\
\hline $\mathrm{Zr}$ & 11 & 8 & 8 & 8 & 13 & 10 & 10 & 8 \\
\hline Th & 0.23 & 0.08 & 0.05 & 0.05 & 0.46 & 0.22 & 0.33 & 2.16 \\
\hline $\mathrm{U}$ & 0.05 & 0.02 & 0.01 & 0.04 & 0.08 & 0.04 & 0.04 & 0.61 \\
\hline Y & 6 & 2 & 4 & 4 & 4 & 3 & 7 & 7 \\
\hline $\mathrm{La}$ & 1.56 & 1.01 & 0.95 & 0.83 & 2.02 & 1.40 & 1.36 & 5.21 \\
\hline $\mathrm{Ce}$ & 3.60 & 2.27 & 2.29 & 2.00 & 4.54 & 3.21 & 4.71 & 13.46 \\
\hline $\operatorname{Pr}$ & 0.48 & 0.31 & 0.34 & 0.27 & 0.56 & 0.43 & 0.84 & 1.87 \\
\hline $\mathrm{Nd}$ & 2.18 & 1.35 & 1.76 & 1.33 & 2.28 & 1.95 & 4.37 & 9.03 \\
\hline $\mathrm{Sm}$ & 0.59 & 0.37 & 0.59 & 0.41 & 0.53 & 0.51 & 1.29 & 2.89 \\
\hline $\mathrm{Eu}$ & 0.45 & 0.34 & 0.41 & 0.30 & 0.45 & 0.41 & 0.37 & 0.95 \\
\hline Gd & 0.83 & 0.42 & 0.89 & 0.60 & 0.62 & 0.59 & 1.44 & 4.03 \\
\hline $\mathrm{Tb}$ & 0.14 & 0.07 & 0.14 & 0.10 & 0.09 & 0.09 & 0.23 & 0.76 \\
\hline Dy & 0.99 & 0.49 & 0.94 & 0.68 & 0.58 & 0.58 & 1.35 & 5.29 \\
\hline Но & 0.23 & 0.10 & 0.20 & 0.14 & 0.12 & 0.11 & 0.26 & 1.18 \\
\hline Er & 0.69 & 0.31 & 0.55 & 0.42 & 0.35 & 0.32 & 0.74 & 3.58 \\
\hline $\mathrm{Tm}$ & 0.10 & 0.04 & 0.08 & 0.06 & 0.05 & 0.05 & 0.09 & 0.53 \\
\hline $\mathrm{Yb}$ & 0.74 & 0.30 & 0.48 & 0.38 & 0.31 & 0.27 & 0.59 & 3.60 \\
\hline $\mathrm{Lu}$ & 0.12 & 0.05 & 0.07 & 0.05 & 0.04 & 0.04 & 0.08 & 0.55 \\
\hline $\mathrm{Cu}$ & 11.09 & 112.18 & 12.69 & 23.94 & 29.74 & 16.49 & 12.52 & 72.20 \\
\hline $\mathrm{Zn}$ & 71 & 165 & 173 & 61 & 48 & 48 & 113 & 160 \\
\hline $\mathrm{Ga}$ & 47 & 51 & 92 & 60 & 68 & 60 & 52 & 59 \\
\hline $\mathrm{Pb}$ & 2.50 & 0.34 & 2.29 & 4.70 & 9.76 & 5.59 & 9.00 & 6.98 \\
\hline $\mathrm{La} / \mathrm{Sm}_{\mathrm{cn}}$ & 1.72 & 1.75 & 1.04 & 1.30 & 2.46 & 1.76 & 0.68 & 1.16 \\
\hline $\mathrm{La} / \mathrm{Yb}_{\mathrm{cn}}$ & 1.51 & 2.40 & 1.42 & 1.57 & 4.69 & 3.67 & 1.66 & 1.04 \\
\hline $\mathrm{Gd} / \mathrm{Yb}_{\mathrm{cn}}$ & 0.92 & 1.15 & 1.54 & 1.30 & 1.67 & 1.80 & 2.02 & 0.93 \\
\hline $\mathrm{Eu} / \mathrm{Eu}^{*}$ & 1.97 & 2.60 & 1.71 & 1.87 & 2.38 & 2.25 & 0.84 & 0.85 \\
\hline $\mathrm{Ce} / \mathrm{Ce}^{*}$ & 1.02 & 1.00 & 0.98 & 1.03 & 1.05 & 1.01 & 1.08 & 1.06 \\
\hline $\mathrm{Al}_{2} \mathrm{O}_{3} / \mathrm{TiO}_{2}$ & 62 & 85 & 28 & 149 & 188 & 163 & 133 & 125 \\
\hline $\mathrm{Y} / \mathrm{Ho}$ & 26.3 & 19.9 & 20.4 & 28.1 & 34.0 & 26.1 & 26.9 & 5.9 \\
\hline $\mathrm{Nb} / \mathrm{Ta}$ & 12.1 & 13.2 & 16.5 & 14.1 & 16.5 & 18.0 & 14.9 & 13.7 \\
\hline $\mathrm{Zr} / \mathrm{Y}$ & 1.83 & 4.00 & 2.00 & 2.00 & 3.25 & 3.33 & 1.43 & 1.14 \\
\hline $\mathrm{Ti} / \mathrm{Zr}$ & 183 & 208 & 692 & 135 & 69 & 101 & 117 & 159 \\
\hline $\mathrm{Nb} / \mathrm{Nb}^{*}$ & 0.43 & 0.54 & 0.78 & 0.88 & 0.33 & 0.44 & 0.36 & 0.40 \\
\hline $\mathrm{Zr} / \mathrm{Zr} *$ & 0.67 & 0.78 & 0.54 & 0.75 & 0.82 & 0.69 & 0.29 & 0.11 \\
\hline $\mathrm{Ti} / \mathrm{Ti}^{*}$ & 1.01 & 1.35 & 2.81 & 0.77 & 0.52 & 0.63 & 0.49 & 0.20 \\
\hline $\mathrm{Sr} / \mathrm{Y}$ & 24 & 56 & 52 & 35 & 49 & 57 & 18 & 12 \\
\hline North & 517336 & 517336 & 517280 & 518811 & 518736 & 518911 & 526661 & 526511 \\
\hline East & 5393713 & 5393713 & 5393561 & 5393580 & 5393410 & 5393607 & 5399551 & 5399464 \\
\hline
\end{tabular}

(a): Variably altered sample. 
Table 3. Continued.

\begin{tabular}{|c|c|c|c|c|c|c|c|c|}
\hline Sample\# & BVL2013-068 & BVL2013-069 & BVL2013-070 & BVL2013-072 & BVL2013-074 & BVL2013-076 & BVL2013-077 & BVL2013-079 \\
\hline $\mathrm{SiO}_{2}$ & 47.0 & 46.8 & 45.1 & 46.9 & 47.1 & 44.4 & 44.1 & 45.8 \\
\hline $\mathrm{TiO}_{2}$ & 0.29 & 0.17 & 0.16 & 0.19 & 0.26 & 0.14 & 0.18 & 0.77 \\
\hline $\mathrm{Al}_{2} \mathrm{O}_{3}$ & 28.2 & 27.4 & 28.8 & 26.4 & 28.0 & 26.1 & 27.1 & 25.8 \\
\hline $\mathrm{Fe}_{2} \mathrm{O}_{3}(\mathrm{~T})$ & 3.2 & 3.1 & 5.0 & 5.3 & 2.7 & 6.8 & 6.3 & 6.4 \\
\hline $\mathrm{MnO}$ & 0.075 & 0.06 & 0.064 & 0.06 & 0.059 & 0.076 & 0.052 & 0.062 \\
\hline $\mathrm{MgO}$ & 1.5 & 2.1 & 3.3 & 2.6 & 0.7 & 3.6 & 1.8 & 3.1 \\
\hline $\mathrm{CaO}$ & 13.6 & 17.1 & 12.0 & 13.5 & 15.8 & 11.5 & 12.9 & 13.0 \\
\hline $\mathrm{K}_{2} \mathrm{O}$ & 0.56 & 0.03 & 0.79 & 0.39 & 0.12 & 0.63 & 1.02 & 0.08 \\
\hline $\mathrm{Na}_{2} \mathrm{O}$ & 3.24 & 1.37 & 2.57 & 2.47 & 3.46 & 3.06 & 2.5 & 2.94 \\
\hline $\mathrm{P}_{2} \mathrm{O}_{5}$ & 0.02 & 0.01 & $<0.01$ & 0.02 & 0.04 & $<0.01$ & 0.02 & 0.02 \\
\hline LOI & 3.0 & 2.9 & 3.0 & 2.8 & 2.0 & 3.5 & 2.6 & 2.8 \\
\hline Mg-number & 47.2 & 56.8 & 56.5 & 49.6 & 34.9 & 50.9 & 36.0 & 48.8 \\
\hline $\mathrm{Cr}$ & 19 & 307 & 518 & 104 & 9 & 15 & 37 & 32 \\
\hline Co & 10 & 12 & 19 & 11 & 6 & 23 & 16 & 22 \\
\hline $\mathrm{Ni}$ & 34 & 40 & 45 & 41 & 28 & 72 & 39 & 83 \\
\hline $\mathrm{Rb}$ & 13.13 & 0.77 & 17.89 & 9.99 & 2.70 & 15.67 & 26.65 & 2.35 \\
\hline $\mathrm{Sr}$ & 176 & 171 & 138 & 141 & 218 & 146 & 149 & 185 \\
\hline $\mathrm{Ba}$ & 91 & 4 & 102 & 54 & 21 & 96 & 90 & 17 \\
\hline $\mathrm{Sc}$ & 7 & 16 & 20 & 18 & 6 & 6 & 10 & 17 \\
\hline V & 67 & 71 & 81 & 84 & 56 & 49 & 119 & 59 \\
\hline Тa & 0.05 & 0.01 & 0.01 & 0.02 & 0.04 & 0.01 & 0.02 & 0.08 \\
\hline $\mathrm{Nb}$ & 0.66 & 0.26 & 0.30 & 0.31 & 0.59 & 0.29 & 0.42 & 1.21 \\
\hline $\mathrm{Zr}$ & 18 & 5 & 6 & 13 & 16 & 6 & 10 & 24 \\
\hline Th & 0.05 & 4.00 & 7.05 & 0.01 & 3.61 & 0.11 & 3.18 & 2.83 \\
\hline $\mathrm{U}$ & 0.05 & 0.04 & 0.07 & 0.06 & 0.08 & 0.03 & 0.82 & 0.10 \\
\hline Y & 5 & 4 & 4 & 7 & 4 & 2 & 10 & 6 \\
\hline $\mathrm{La}$ & 1.13 & 0.59 & 1.10 & 2.23 & 1.13 & 0.44 & 4.73 & 3.73 \\
\hline $\mathrm{Ce}$ & 2.57 & 1.48 & 2.33 & 4.94 & 2.93 & 0.97 & 9.83 & 8.55 \\
\hline $\operatorname{Pr}$ & 0.34 & 0.21 & 0.31 & 0.67 & 0.41 & 0.13 & 1.21 & 1.16 \\
\hline $\mathrm{Nd}$ & 1.50 & 1.06 & 1.44 & 2.97 & 1.87 & 0.60 & 4.91 & 4.88 \\
\hline $\mathrm{Sm}$ & 0.43 & 0.36 & 0.43 & 0.79 & 0.49 & 0.20 & 1.15 & 1.00 \\
\hline $\mathrm{Eu}$ & 0.39 & 0.26 & 0.74 & 0.51 & 0.38 & 0.31 & 0.99 & 0.71 \\
\hline Gd & 0.79 & 0.49 & 0.59 & 1.00 & 0.56 & 0.31 & 1.31 & 1.02 \\
\hline $\mathrm{Tb}$ & 0.10 & 0.08 & 0.10 & 0.17 & 0.10 & 0.05 & 0.21 & 0.16 \\
\hline Dy & 0.59 & 0.55 & 0.63 & 1.12 & 0.61 & 0.37 & 1.44 & 0.98 \\
\hline Но & 0.13 & 0.12 & 0.14 & 0.24 & 0.13 & 0.08 & 0.30 & 0.20 \\
\hline $\mathrm{Er}$ & 0.39 & 0.36 & 0.38 & 0.72 & 0.37 & 0.24 & 0.86 & 0.60 \\
\hline $\mathrm{Tm}$ & 0.06 & 0.05 & 0.05 & 0.10 & 0.06 & 0.03 & 0.11 & 0.08 \\
\hline $\mathrm{Yb}$ & 0.39 & 0.32 & 0.33 & 0.66 & 0.36 & 0.25 & 0.72 & 0.53 \\
\hline $\mathrm{Lu}$ & 0.06 & 0.05 & 0.05 & 0.09 & 0.05 & 0.04 & 0.10 & 0.08 \\
\hline $\mathrm{Cu}$ & 143.99 & 11.34 & 21.82 & 84.84 & 19.57 & 5.30 & 37.12 & 81.33 \\
\hline $\mathrm{Zn}$ & 102 & 176 & 58 & 59 & 38 & 57 & 50 & 61 \\
\hline $\mathrm{Ga}$ & 68 & 52 & 66 & 57 & 58 & 64 & 75 & 55 \\
\hline $\mathrm{Pb}$ & 8.86 & 22.14 & 5.55 & 1.74 & 7.03 & 5.07 & 4.33 & 7.47 \\
\hline $\mathrm{La} / \mathrm{Sm}_{\mathrm{cn}}$ & 1.68 & 1.07 & 1.64 & 1.82 & 1.51 & 1.42 & 2.66 & 2.40 \\
\hline $\mathrm{La} / \mathrm{Yb}_{\mathrm{cn}}$ & 2.09 & 1.31 & 2.36 & 2.44 & 2.23 & 1.28 & 4.68 & 5.00 \\
\hline $\mathrm{Gd} / \mathrm{Yb}_{\mathrm{cn}}$ & 1.68 & 1.25 & 1.46 & 1.26 & 1.28 & 1.04 & 1.50 & 1.57 \\
\hline $\mathrm{Eu} / \mathrm{Eu}^{*}$ & 2.03 & 1.92 & 4.49 & 1.74 & 2.22 & 3.76 & 2.47 & 2.16 \\
\hline $\mathrm{Ce} / \mathrm{Ce}^{*}$ & 1.02 & 1.02 & 0.98 & 0.99 & 1.05 & 0.99 & 1.01 & 1.01 \\
\hline $\mathrm{Al}_{2} \mathrm{O}_{3} / \mathrm{TiO}_{2}$ & 99 & 162 & 182 & 139 & 107 & 193 & 155 & 33 \\
\hline Y/Ho & 37.7 & 33.0 & 29.6 & 29.3 & 31.8 & 25.5 & 33.4 & 29.9 \\
\hline $\mathrm{Nb} / \mathrm{Ta}$ & 22.0 & 20.6 & 14.5 & 16.0 & 21.1 & 20.4 & 15.9 & 19.3 \\
\hline $\mathrm{Zr} / \mathrm{Y}$ & 3.60 & 1.25 & 1.50 & 1.86 & 4.00 & 3.00 & 1.00 & 4.00 \\
\hline $\mathrm{Ti} / \mathrm{Zr}$ & 95 & 203 & 158 & 87 & 98 & 135 & 105 & 193 \\
\hline $\mathrm{Nb} / \mathrm{Nb}^{*}$ & 1.10 & 0.10 & 0.08 & 1.76 & 0.13 & 0.63 & 0.14 & 0.22 \\
\hline $\mathrm{Zr} / \mathrm{Zr} *$ & 1.54 & 0.56 & 0.53 & 0.59 & 1.16 & 1.20 & 0.29 & 0.75 \\
\hline $\mathrm{Ti} / \mathrm{Ti}^{*}$ & 0.95 & 0.86 & 0.44 & 0.49 & 1.04 & 0.81 & 0.28 & 1.66 \\
\hline $\mathrm{Sr} / \mathrm{Y}$ & 35 & 43 & 34 & 20 & 55 & 73 & 15 & 31 \\
\hline North & 525876 & 525458 & 525185 & 525362 & 525964 & 525806 & 525564 & 525727 \\
\hline East & 5399371 & 5398806 & 5398429 & 5398224 & 5398182 & 5397291 & 5396817 & 5396582 \\
\hline
\end{tabular}


Table 3. Continued.

\begin{tabular}{|c|c|c|}
\hline Sample\# & BVL2013-080 & BVL2013-081 \\
\hline $\mathrm{SiO}_{2}$ & 49.7 & 48.4 \\
\hline $\mathrm{TiO}_{2}$ & 0.20 & 0.46 \\
\hline $\mathrm{Al}_{2} \mathrm{O}_{3}$ & 24.6 & 20.4 \\
\hline $\mathrm{Fe}_{2} \mathrm{O}_{3}(\mathrm{~T})$ & 3.3 & 10.4 \\
\hline $\mathrm{MnO}$ & 0.081 & 0.107 \\
\hline $\mathrm{MgO}$ & 1.3 & 3.8 \\
\hline $\mathrm{CaO}$ & 17.4 & 9.6 \\
\hline $\mathrm{K}_{2} \mathrm{O}$ & 0.02 & 0.27 \\
\hline $\mathrm{Na}_{2} \mathrm{O}$ & 0.19 & 2.31 \\
\hline $\mathrm{P}_{2} \mathrm{O}_{5}$ & 0.02 & 0.02 \\
\hline LOI & 2.8 & 4.1 \\
\hline Mg-number & 42.7 & 42.0 \\
\hline $\mathrm{Cr}$ & 350 & 64 \\
\hline $\mathrm{Co}$ & 9 & 39 \\
\hline $\mathrm{Ni}$ & 36 & 74 \\
\hline $\mathrm{Rb}$ & 0.92 & 5.61 \\
\hline $\mathrm{Sr}$ & 191 & 211 \\
\hline $\mathrm{Ba}$ & 6 & 78 \\
\hline $\mathrm{Sc}$ & 21 & 14 \\
\hline $\mathrm{V}$ & 81 & 174 \\
\hline $\mathrm{Ta}$ & 0.01 & 0.16 \\
\hline $\mathrm{Nb}$ & 0.26 & 2.01 \\
\hline $\mathrm{Zr}$ & 9 & 51 \\
\hline Th & 0.15 & 1.70 \\
\hline $\mathrm{U}$ & 0.01 & 0.18 \\
\hline $\mathrm{Y}$ & 5 & 8 \\
\hline $\mathrm{La}$ & 0.80 & 6.51 \\
\hline $\mathrm{Ce}$ & 1.87 & 14.25 \\
\hline $\operatorname{Pr}$ & 0.27 & 1.71 \\
\hline $\mathrm{Nd}$ & 1.34 & 6.66 \\
\hline $\mathrm{Sm}$ & 0.43 & 1.49 \\
\hline $\mathrm{Eu}$ & 0.36 & 0.68 \\
\hline $\mathrm{Gd}$ & 0.58 & 1.58 \\
\hline $\mathrm{Tb}$ & 0.11 & 0.26 \\
\hline Dy & 0.71 & 1.54 \\
\hline Ho & 0.16 & 0.32 \\
\hline $\mathrm{Er}$ & 0.46 & 0.94 \\
\hline $\mathrm{Tm}$ & 0.06 & 0.14 \\
\hline $\mathrm{Yb}$ & 0.43 & 0.85 \\
\hline $\mathrm{Lu}$ & 0.06 & 0.13 \\
\hline $\mathrm{Cu}$ & 8.92 & 1.61 \\
\hline $\mathrm{Zn}$ & 71 & 95 \\
\hline $\mathrm{Ga}$ & 52 & 64 \\
\hline $\mathrm{Pb}$ & 3.92 & 2.12 \\
\hline $\mathrm{La} / \mathrm{Sm}_{\mathrm{cn}}$ & 1.19 & 2.82 \\
\hline $\mathrm{La} / \mathrm{Yb}_{\mathrm{cn}}$ & 1.31 & 5.48 \\
\hline $\mathrm{Gd} / \mathrm{Yb}_{\mathrm{cn}}$ & 1.11 & 1.54 \\
\hline $\mathrm{Eu} / \mathrm{Eu}^{*}$ & 2.21 & 1.35 \\
\hline $\mathrm{Ce} / \mathrm{Ce}^{*}$ & 0.99 & 1.05 \\
\hline $\mathrm{Al}_{2} \mathrm{O}_{3} / \mathrm{TiO}_{2}$ & 126 & 45 \\
\hline Y/Ho & 32.1 & 24.7 \\
\hline $\mathrm{Nb} / \mathrm{Ta}$ & 12.8 & \\
\hline $\mathrm{Zr} / \mathrm{Y}$ & 1.80 & 6.38 \\
\hline $\mathrm{Ti} / \mathrm{Zr}$ & 131 & 53 \\
\hline $\mathrm{Nb} / \mathrm{Nb}^{*}$ & 0.48 & 0.32 \\
\hline $\mathrm{Zr} / \mathrm{Zr*}$ & 0.82 & 1.12 \\
\hline $\mathrm{Ti} / \mathrm{Ti}^{*}$ & 0.78 & 0.81 \\
\hline$\underline{\mathrm{Sr} / \mathrm{Y}}$ & 38 & 26 \\
\hline North & 520364 & 519469 \\
\hline East & 5396381 & 5395238 \\
\hline
\end{tabular}


Table 4. Major (wt.\%) and trace (ppm) element concentrations and significant element ratios for the gabbros in the BVLA Complex.

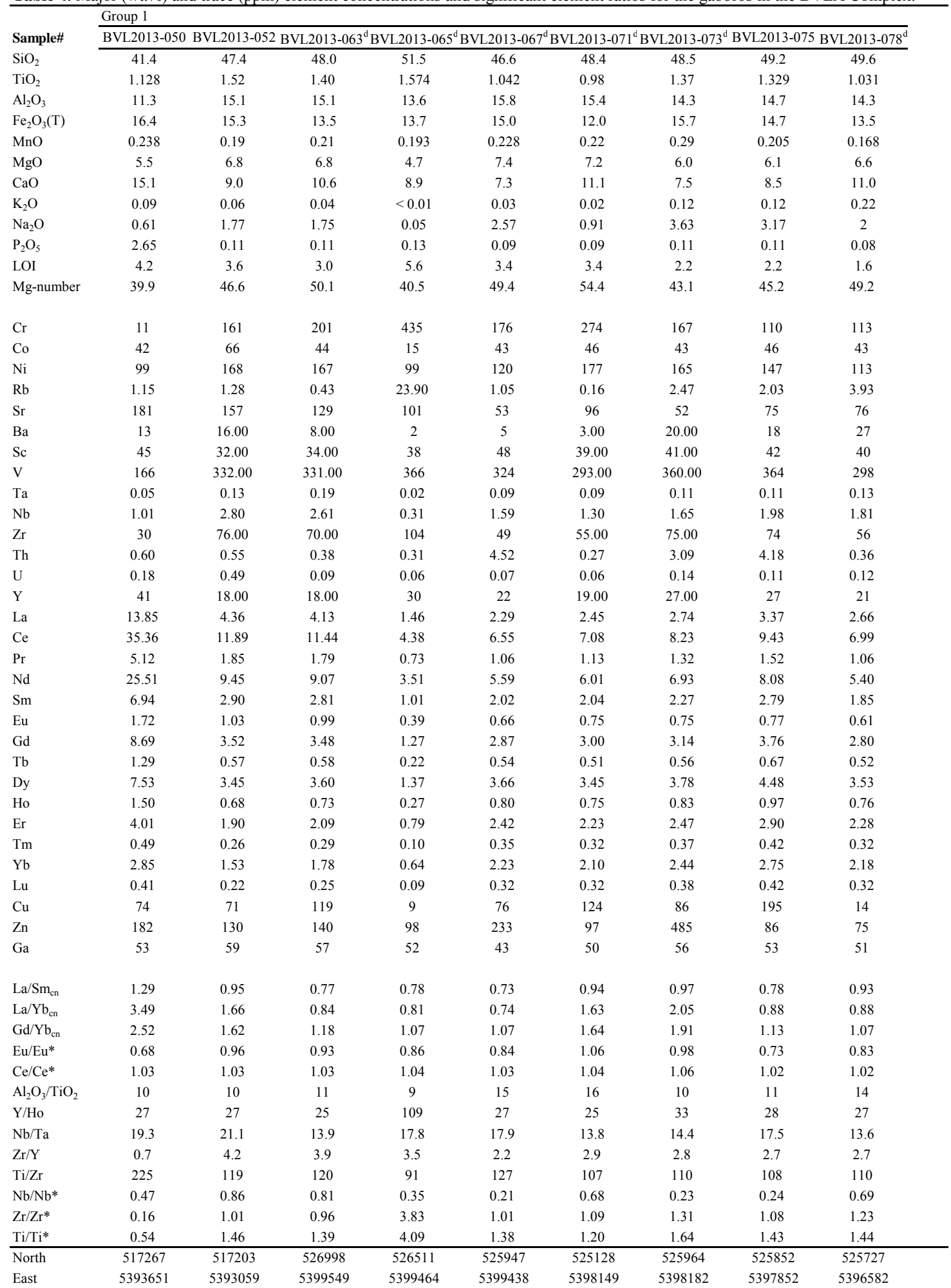

d: Microgabbro occurring as dykes 


\begin{tabular}{|c|c|c|c|c|c|}
\hline & Group 2 & & & & \\
\hline Sample\# & BVL2013-083 & BVL2013-084 & BVL2013-085 ${ }^{\mathrm{d}}$ & BVL2013-086 & BVL2013-087 \\
\hline $\mathrm{SiO}_{2}$ & 43.6 & 42.4 & 41.0 & 44.6 & 47.0 \\
\hline $\mathrm{TiO}_{2}$ & 0.899 & 0.76 & 0.487 & 0.976 & 0.568 \\
\hline $\mathrm{Al}_{2} \mathrm{O}_{3}$ & 22.6 & 15.6 & 16.7 & 17.2 & 18.1 \\
\hline $\mathrm{Fe}_{2} \mathrm{O}_{3}(\mathrm{~T})$ & 11.4 & 15.6 & 16.4 & 14.2 & 13.4 \\
\hline $\mathrm{MnO}$ & 0.123 & 0.21 & 0.201 & 0.194 & 0.178 \\
\hline $\mathrm{MgO}$ & 4.7 & 8.3 & 6.9 & 7.3 & 6.6 \\
\hline $\mathrm{CaO}$ & 11.9 & 12.5 & 9.1 & 8.9 & 9.0 \\
\hline $\mathrm{K}_{2} \mathrm{O}$ & 0.16 & 0.04 & 0.02 & 0.02 & 0.02 \\
\hline $\mathrm{Na}_{2} \mathrm{O}$ & 1.19 & 0.47 & 1.04 & 0.84 & 1.65 \\
\hline $\mathrm{P}_{2} \mathrm{O}_{5}$ & 0.02 & 0.03 & 0.01 & 0.02 & 0.02 \\
\hline LOI & 4.2 & 3.5 & 8.3 & 4.8 & 4.0 \\
\hline Mg-number & 45.1 & 51.3 & 45.4 & 50.4 & 49.4 \\
\hline $\mathrm{Cr}$ & 192 & 234 & 90 & 394 & 197 \\
\hline Co & 43 & 56 & 54 & 45 & 48 \\
\hline $\mathrm{Ni}$ & 83 & 137 & 137 & 147 & 109 \\
\hline $\mathrm{Rb}$ & 3.51 & 0.42 & 0.36 & 0.25 & 0.29 \\
\hline $\mathrm{Sr}$ & 192 & 187 & 157 & 234 & 204 \\
\hline $\mathrm{Ba}$ & 46 & 8 & 7 & 8 & 12 \\
\hline $\mathrm{Sc}$ & 39 & 41 & 21 & 39 & 25 \\
\hline V & 370 & 284 & 192 & 329 & 200 \\
\hline $\mathrm{Ta}$ & 0.04 & 0.02 & 0.02 & 0.03 & 0.03 \\
\hline $\mathrm{Nb}$ & 0.66 & 0.27 & 0.30 & 0.43 & 0.47 \\
\hline $\mathrm{Zr}$ & 8 & 5 & 5 & 7 & 6 \\
\hline Th & 0.08 & 0.03 & 0.00 & 0.02 & 0.01 \\
\hline $\mathrm{U}$ & 0.01 & 0.01 & 0.01 & 0.01 & 0.01 \\
\hline Y & 4 & 4 & 2 & 5 & 3 \\
\hline $\mathrm{La}$ & 0.81 & 0.55 & 0.65 & 0.75 & 0.79 \\
\hline $\mathrm{Ce}$ & 2.03 & 1.47 & 1.52 & 1.96 & 1.80 \\
\hline $\operatorname{Pr}$ & 0.31 & 0.24 & 0.22 & 0.30 & 0.25 \\
\hline $\mathrm{Nd}$ & 1.64 & 1.32 & 1.10 & 1.63 & 1.12 \\
\hline $\mathrm{Sm}$ & 0.57 & 0.52 & 0.36 & 0.63 & 0.35 \\
\hline $\mathrm{Eu}$ & 0.47 & 0.45 & 0.48 & 0.55 & 0.44 \\
\hline $\mathrm{Gd}$ & 0.89 & 0.91 & 0.54 & 1.04 & 0.53 \\
\hline $\mathrm{Tb}$ & 0.15 & 0.14 & 0.09 & 0.17 & 0.09 \\
\hline Dy & 1.00 & 0.94 & 0.60 & 1.10 & 0.65 \\
\hline Но & 0.21 & 0.19 & 0.12 & 0.24 & 0.15 \\
\hline Er & 0.59 & 0.55 & 0.39 & 0.73 & 0.47 \\
\hline $\mathrm{Tm}$ & 0.08 & 0.08 & 0.05 & 0.10 & 0.07 \\
\hline $\mathrm{Yb}$ & 0.56 & 0.52 & 0.36 & 0.70 & 0.52 \\
\hline $\mathrm{Lu}$ & 0.08 & 0.08 & 0.06 & 0.11 & 0.09 \\
\hline $\mathrm{Cu}$ & 2 & 5 & 2 & 3 & 2 \\
\hline $\mathrm{Zn}$ & 109 & 200 & 142 & 128 & 111 \\
\hline $\mathrm{Ga}$ & 58 & 43 & 46 & 50 & 47 \\
\hline $\mathrm{La} / \mathrm{Sm}_{\mathrm{cn}}$ & 0.91 & 0.68 & 1.15 & 0.77 & 1.47 \\
\hline $\mathrm{La} / \mathrm{Yb}_{\mathrm{cn}}$ & 1.04 & 0.76 & 1.29 & 0.77 & 1.09 \\
\hline $\mathrm{Gd} / \mathrm{Yb}_{\mathrm{cn}}$ & 1.32 & 1.44 & 1.25 & 1.23 & 0.84 \\
\hline $\mathrm{Eu} / \mathrm{Eu}^{*}$ & 2.03 & 2.01 & 3.33 & 2.08 & 3.18 \\
\hline $\mathrm{Ce} / \mathrm{Ce}^{*}$ & 1.00 & 1.00 & 0.99 & 1.01 & 1.00 \\
\hline $\mathrm{Al}_{2} \mathrm{O}_{3} / \mathrm{TiO}_{2}$ & 25 & 20 & 34 & 18 & 32 \\
\hline Y/Ho & 19.4 & 21.1 & 16.1 & 20.8 & 19.9 \\
\hline $\mathrm{Nb} / \mathrm{Ta}$ & 17.0 & 12.8 & 14.3 & 14.3 & 16.9 \\
\hline $\mathrm{Zr} / \mathrm{Y}$ & 2.0 & 1.3 & 2.5 & 1.4 & 2.0 \\
\hline $\mathrm{Ti} / \mathrm{Zr}$ & 674 & 911 & 584 & 836 & 567 \\
\hline $\mathrm{Nb} / \mathrm{Nb}^{*}$ & 0.96 & 0.93 & 3.08 & 1.45 & 2.40 \\
\hline $\mathrm{Zr} / \mathrm{Zr} *$ & 0.57 & 0.42 & 0.55 & 0.48 & 0.67 \\
\hline $\mathrm{Ti} / \mathrm{Ti}^{*}$ & 2.55 & 2.18 & 1.75 & 2.37 & 2.15 \\
\hline North & 518919 & 519343 & 519570 & 519770 & 519770 \\
\hline East & 5395033 & 5395783 & 5396053 & 5396183 & 5396183 \\
\hline
\end{tabular}


Table 5. Major (wt.\%) and trace (ppm) element concentrations and significant element ratios for the Bad Vermilion Lake granitic rocks

\begin{tabular}{|c|c|c|c|c|c|}
\hline Sample\# & BVL2013-041 & BVL2013-042 & BVL2013-043 & BVL2013-044 & BVL2013-045 \\
\hline $\mathrm{SiO}_{2}$ & 75.6 & 76.5 & 77.3 & 77.1 & 77.8 \\
\hline $\mathrm{TiO}_{2}$ & 0.27 & 0.17 & 0.17 & 0.17 & 0.19 \\
\hline $\mathrm{Al}_{2} \mathrm{O}_{3}$ & 11.1 & 11.5 & 11.6 & 11.6 & 10.8 \\
\hline $\mathrm{Fe}_{2} \mathrm{O}_{3}(\mathrm{~T})$ & 5.57 & 1.98 & 2.50 & 1.65 & 2.51 \\
\hline $\mathrm{MnO}$ & 0.02 & 0.04 & 0.04 & 0.04 & 0.06 \\
\hline $\mathrm{MgO}$ & 0.15 & 0.06 & 0.07 & 0.03 & 0.09 \\
\hline $\mathrm{CaO}$ & 1.84 & 1.95 & 1.69 & 1.96 & 2.51 \\
\hline $\mathrm{K}_{2} \mathrm{O}$ & 0.26 & 1.04 & 2.13 & 0.72 & 0.75 \\
\hline $\mathrm{Na}_{2} \mathrm{O}$ & 5.11 & 4.91 & 2.75 & 5.10 & 4.62 \\
\hline $\mathrm{P}_{2} \mathrm{O}_{5}$ & 0.02 & 0.01 & 0.02 & 0.02 & 0.04 \\
\hline LOI & 0.53 & 1.97 & 1.99 & 1.85 & 1.61 \\
\hline Mg-number & 5.1 & 5.7 & 5.3 & 3.5 & 6.6 \\
\hline $\mathrm{Cr}$ & b.d & 12.08 & b.d & b.d & 17.44 \\
\hline $\mathrm{Co}$ & 1.53 & 0.66 & 0.63 & 0.43 & 0.58 \\
\hline $\mathrm{Ni}$ & 14 & 10 & 10 & 9 & 8 \\
\hline $\mathrm{Rb}$ & 3 & 15 & 35 & 14 & 14 \\
\hline $\mathrm{Sr}$ & 128 & 59 & 73 & 66 & 120 \\
\hline $\mathrm{Ba}$ & 257 & 505 & 622 & 381 & 438 \\
\hline $\mathrm{Sc}$ & 2.00 & 1.00 & 1.00 & $<1$ & 2.00 \\
\hline $\mathrm{V}$ & 0.30 & 1.06 & 0.67 & -0.20 & 0.77 \\
\hline $\mathrm{Ta}$ & 0.74 & 1.62 & 1.59 & 1.68 & 0.86 \\
\hline $\mathrm{Nb}$ & 13.7 & 20.5 & 20.5 & 22.0 & 21.2 \\
\hline $\mathrm{Zr}$ & 558 & 411 & 367 & 404 & 407 \\
\hline Th & 7.94 & 9.90 & 10.38 & 11.10 & 10.09 \\
\hline U & 1.36 & 2.06 & 2.58 & 2.40 & 1.90 \\
\hline $\mathrm{Y}$ & 102 & 95 & 163 & 168 & 127 \\
\hline $\mathrm{La}$ & 37.9 & 49.9 & 59.5 & 60.1 & 56.6 \\
\hline $\mathrm{Ce}$ & 95.8 & 120.7 & 137.7 & 147.0 & 129.1 \\
\hline $\operatorname{Pr}$ & 12.9 & 15.5 & 17.3 & 19.0 & 16.5 \\
\hline $\mathrm{Nd}$ & 55.7 & 67.0 & 72.3 & 81.0 & 70.7 \\
\hline $\mathrm{Sm}$ & 14.1 & 16.9 & 17.9 & 20.3 & 17.6 \\
\hline $\mathrm{Eu}$ & 2.61 & 2.50 & 2.92 & 3.10 & 3.65 \\
\hline $\mathrm{Gd}$ & 16.51 & 18.81 & 20.95 & 24.02 & 20.24 \\
\hline $\mathrm{Tb}$ & 2.86 & 3.16 & 3.75 & 4.12 & 3.54 \\
\hline Dy & 18.81 & 19.53 & 24.95 & 26.91 & 23.55 \\
\hline Ho & 4.04 & & 5.38 & 5.74 & 5.07 \\
\hline $\mathrm{Er}$ & 12.40 & 11.67 & 16.54 & 17.37 & 15.49 \\
\hline $\mathrm{Tm}$ & 1.79 & 1.68 & 2.39 & 2.48 & 2.30 \\
\hline $\mathrm{Yb}$ & 11.53 & 11.11 & 15.49 & 16.19 & 15.35 \\
\hline $\mathrm{Lu}$ & 1.66 & 1.65 & 2.27 & 2.37 & 2.35 \\
\hline $\mathrm{Cu}$ & 14 & 8 & 6 & 4 & 22 \\
\hline $\mathrm{Zn}$ & 133 & 67 & 57 & 48 & 79 \\
\hline $\mathrm{Ga}$ & 102 & 141 & 158 & 131 & 132 \\
\hline $\mathrm{Pb}$ & 2.21 & 3.93 & 8.07 & 3.99 & 11.34 \\
\hline $\mathrm{Na}_{2} \mathrm{O}+\mathrm{K}_{2} \mathrm{O}$ & 5.37 & 5.95 & 4.88 & 5.82 & 5.37 \\
\hline $\mathrm{A} / \mathrm{CNK}$ & 0.92 & 0.90 & 1.17 & 0.91 & 0.83 \\
\hline $\mathrm{La} / \mathrm{Sm}_{\mathrm{cn}}$ & 1.74 & 1.91 & 2.15 & 1.91 & 2.07 \\
\hline $\mathrm{La} / \mathrm{Yb}_{\mathrm{cn}}$ & 2.36 & 3.22 & 2.75 & 2.66 & 2.64 \\
\hline $\mathrm{Gd} / \mathrm{Yb}_{\mathrm{cn}}$ & 1.18 & 1.40 & 1.12 & 1.23 & 1.09 \\
\hline $\mathrm{Eu} / \mathrm{Eu}^{*}$ & 0.52 & 0.43 & 0.46 & 0.43 & 0.59 \\
\hline $\mathrm{Ce} / \mathrm{Ce}^{*}$ & 1.06 & 1.06 & 1.05 & 1.07 & 1.04 \\
\hline $\mathrm{Sr} / \mathrm{Y}$ & 0.01 & 0.01 & 0.01 & 0.00 & 0.01 \\
\hline $\mathrm{Nb} / \mathrm{Nb}^{*}$ & 0.47 & 0.42 & 0.42 & 0.42 & 0.59 \\
\hline $\mathrm{Sr} / \mathrm{Sr}^{*}$ & 0.14 & 0.05 & 0.06 & 0.05 & 0.10 \\
\hline $\mathrm{Ti} / \mathrm{Ti}^{*}$ & 0.07 & 0.05 & 0.04 & 0.04 & 0.04 \\
\hline North & 514938 & 515070 & 515030 & 515342 & 515665 \\
\hline East & 5393961 & 5393874 & 5393907 & 5393642 & 5393685 \\
\hline
\end{tabular}

b. d. : Below detection limit 
Table 6. Oxygen isotope compositions of the Bad Vermilion Lake Anorthosite.

\begin{tabular}{lccc}
\hline Sample \# & $\begin{array}{r}\text { Whole rock } \delta^{18} \mathrm{O} \\
\text { (\% VSMOW) }\end{array}$ & $\begin{array}{r}\text { Fresh plagioclase } \delta^{18} \mathrm{O} \\
(\% \text { VSMOW })\end{array}$ & $\begin{array}{c}\text { Altered plagioclase } \delta^{18} \mathrm{O} \\
\text { \%o VSMOW) }\end{array}$ \\
\hline BVL2013-048 & +6.6 & +6.7 & +6.0 \\
BVL2013-064 & +5.7 & +6.4 & +5.3 \\
BVL2013-070 & +5.5 & +6.7 & +6.0 \\
BVL2013-072 & +6.7 & +5.7 & +5.7 \\
BVL2013-077 & +4.9 & +4.8 & +5.8 \\
BVL2013-054 & & +7.2 & \\
BVL2013-068 & & +6.5 & \\
BVL2013-074 & & +5.8 & \\
BVL2013-076 & & +6.6 & \\
BVL2013-079 & & +7.0 & $+5.8 \pm 0.3$ \\
& & & $+5.8 \pm 0.3$ \\
Average & $+5.9 \pm 0.8$ & $+6.3 \pm 0.7$ & \\
Average without BVL2013-077 & $+6.1 \pm 0.6$ & $+6.5 \pm 0.5$ & \\
\hline \hline
\end{tabular}

*Values in bold are the average of replicate analyses 
Metaluminous

\section{Peraluminous}

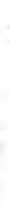

1

0
0.5
0.7
0.9
1.1
1.3

\section{A/CNK}

1.5

1.7

1.9

Supplementary Fig. 1. A/NK versus A/CNK diagram for the Bad Vermilion Lake granitic rocks indicating a metaluminous to peraluminous composition. $\mathrm{A} / \mathrm{NK}=\mathrm{Al} /(\mathrm{Na}+\mathrm{K})($ molar ratio). $\mathrm{A} / \mathrm{CNK}=\mathrm{Al} /(\mathrm{Ca}+\mathrm{Na}+\mathrm{K})$ (molar ratio). 


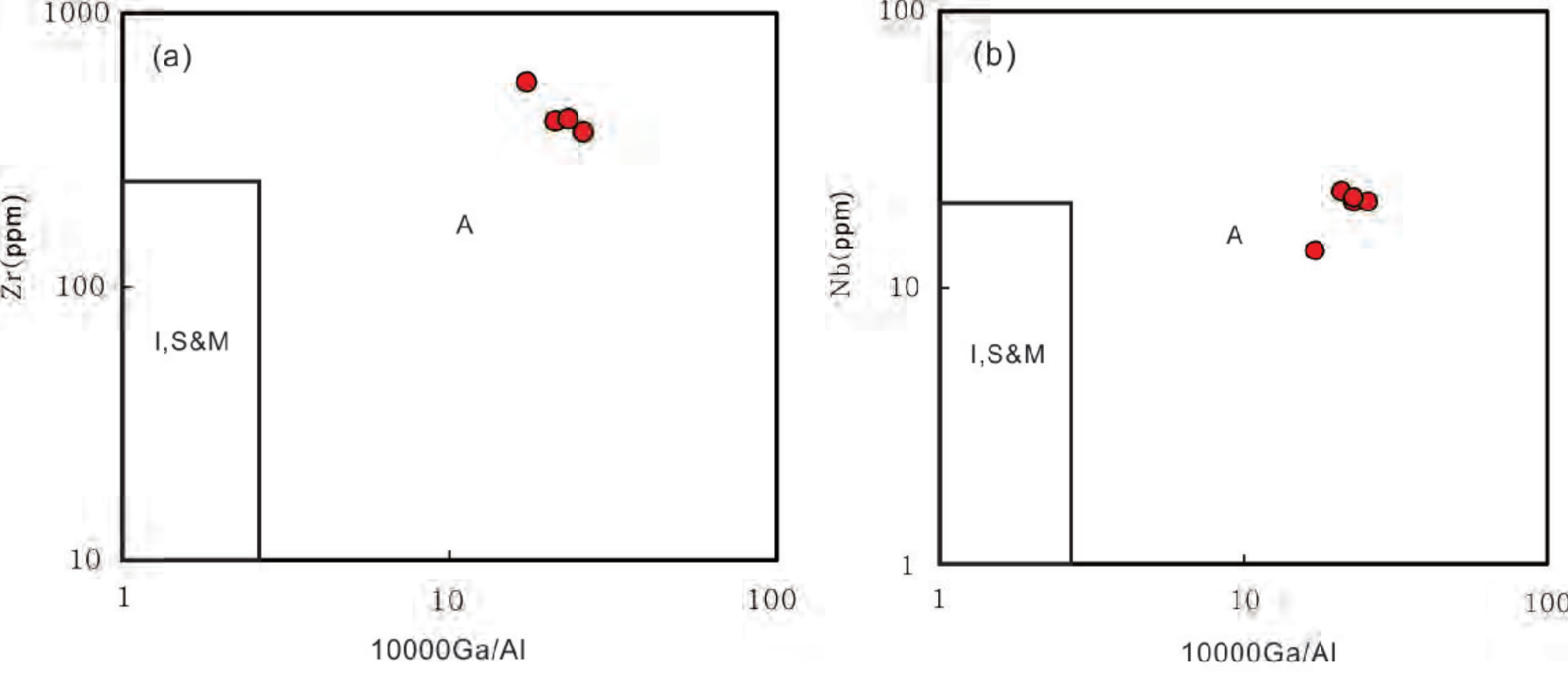

Supplementary Fig. 3. (a) Zr vs. $10000 \mathrm{Ga} / \mathrm{Al}$, (b) Nb vs. $10000 \mathrm{Ga} / \mathrm{Al}$ classification diagrams for granites (after Whalen et al., 1987). I, S, M \& A represent I-, S-, M-, and A-type granites. 

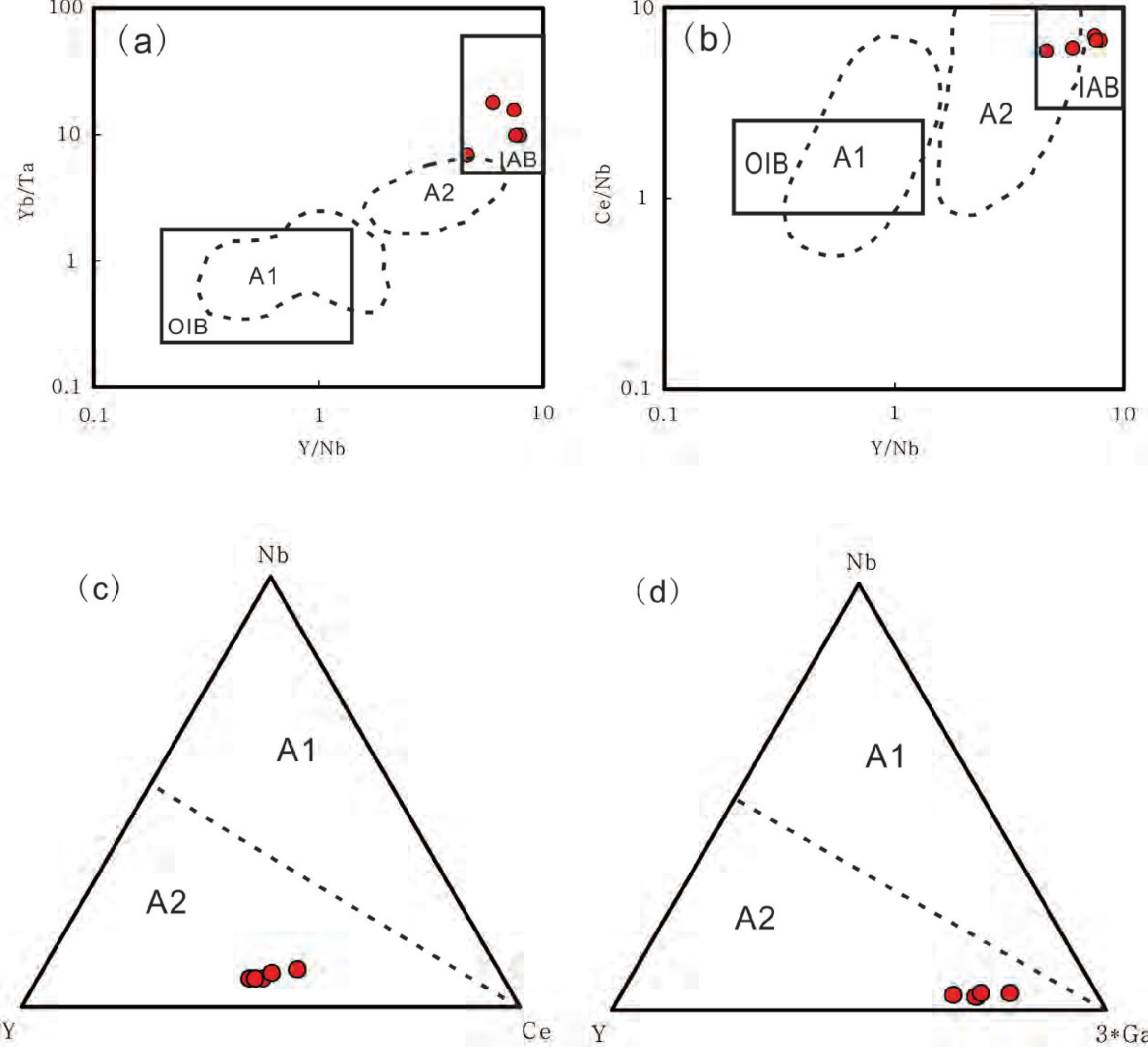

Supplementary Fig. 4. (a). $\mathrm{Yb} / \mathrm{Ta}$ versus $\mathrm{Y} / \mathrm{Nb}$ and (b). $\mathrm{Y} / \mathrm{Nb}$ versus $\mathrm{Ce} / \mathrm{Nb}$ diagrams (Eby, 1992) for the Bad Vermilion Lake granitic rocks. OIB = oceanic island basalt; IAB = island arc basalt. Fields with dashed lines represent A1 - and A2-type granites of Eby (1990). (c) and (d) representative triangular plots showing the areas for A1- and A2-type granitoids. On both diagrams, dashed line corresponds to $\mathrm{Y} / \mathrm{Nb}$ ratios of 1.2 (Eby, 1992). The granitic rocks of this study plot in the field of A2-type granite. 